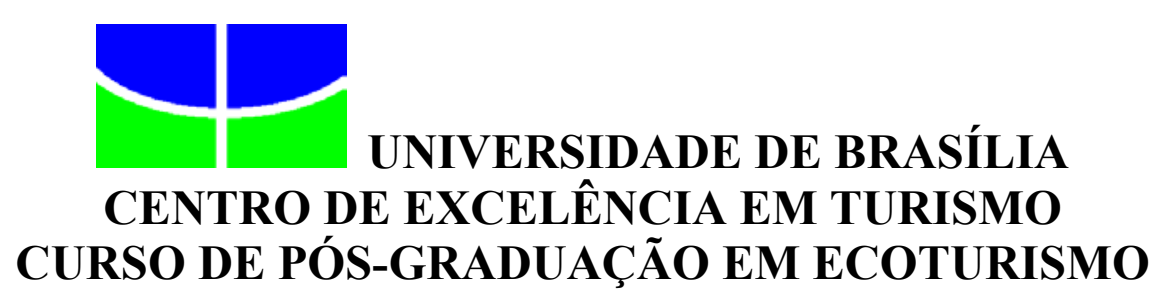

\title{
A CONTRIBUIÇÃO DA MÍDIA EXTERIOR PARA A PROMOÇÃO DO ECOTURISMO
}

\author{
Cíntia Barreto dos Santos
}

Orientador: Prof. Dr. Ayle Salaciê

Monografia apresentada ao Centro de Excelência em Turismo da Universidade de Brasília, como requisito parcial para a obtenção do certificado de Especialista em Ecoturismo. 
UNIVERSIDADE DE BRASÍLIA

Centro de Excelência em Turismo

Curso de Especialização em Ecoturismo

\section{A CONTRIBUIÇÃO DA MÍDIA EXTERIOR PARA A PROMOÇÃO DO ECOTURISMO}

Cíntia Barreto dos Santos

Banca Examinadora:

Ayle Salaciê, Doutor

Orientador

Membro da Banca

Brasília, DF, 25 de março 2003 
SANTOS, Cíntia Barreto

A contribuição da mídia exterior para a promoção do ecoturismo

xii, $65 \mathrm{f}$.

Monografia (especialização) - Universidade de Brasília, Centro de Excelência em Turismo. Brasília, 2003.

Área de Concentração: Turismo

Orientador: Ayle Salaciê

1. Turismo 2. Mídia Exterior 3. Meio-ambiente. 


\section{CÍNTIA BARRETO DOS SANTOS}

\section{A CONTRIBUIÇÃO DA MÍDIA EXTERIOR PARA A PROMOÇÃO DO ECOTURISMO}

Comissão Avaliadora:

Prof. Orientador

Prof. Membro da Banca

Prof. Membro da Banca

Brasília, DF, 25 de março 2003 


\section{DEDICATÓRIA}

Dedico este trabalho a minha filha Gabriela ....

fonte de renovação de conceitos, de atitudes e de vida

A melhoria da qualidade de vida tem real valor quando se pensa nas gerações futuras. 


\section{AGRADECIMENTOS}

Agradeço primeiramente a Deus, pelo insistente milagre da vida.

Agradeço aos criadores e coordenadores deste curso de Ecoturismo, pela ousadia e coragem de propor o que ainda é só conceito.

Agradeço aos colegas de trabalho da Nova Mídia Visuplac.

Agradeço especialmente ao meu Professor orientador, Aylê Salaciê. Sem a sua dedicada atenção e cuidado, esta monografia estaria sem rumo.

Agradeço a todos que tiveram, ou não, paciência de me aturar nesses últimos meses, especialmente à Gabriela, à Emília e ao João Victor, que acabou de nascer.

Muito obrigada a todos. 
"Nós devemos ser a mudança que desejamos ver no mundo”.

M. Gandhi 


\section{RESUMO}

Diante de um crescente movimento de discussões sobre o tema da conservação do meio ambiente e de constantes questionamentos sobre os rumos do modelo de economia adotado na atualidade, surge o desenvolvimento sustentável como uma saída para a garantia dos recursos naturais, conservação do meio ambiente e melhoria da qualidade de vida das populações. Dentro desse quadro, o turismo, reconhecido como um dos mais importantes segmentos econômicos de crescimento e desenvolvimento, inicia um processo de estudos sobre a sustentabilidade de sua atividade. $\mathrm{O}$ ecoturismo surge então como sendo uma oportunidade relevante de exemplo de sustentabilidade. Para que o ecoturismo possa acontecer de fato, é necessário que empresários, comunidades, o terceiro setor, o governo e a própria população (mercado potencial de ecoturismo) venham conhecer seus conceitos e premissas básicas. Para isso, a educação ambiental desponta como a forma de se apresentar essa nova atividade. Por meio do seu argumento e linguagem educativa apropriada, será possível informar e formar conceitos, além de atualizar o conhecimento sobre os assuntos ambientais. Este trabalho propõe-se a discutir as possibilidades de conscientização do público para o ecoturismo por meio da mídia exterior, que apresenta propriedades e vantagens únicas devido a sua integração ao meio ambiente natural landscape - e a sua integração provocativa nas paisagens urbanas. Para isso, sugere-se que haja uma integração das atividades empresariais que tenham interesses mercadológicos ou institucionais no mesmo mercado do ecoturismo ao mercado publicitário. Por meio de parcerias entre estas atividades, será possível levantar investimentos, provenientes da verba de marketing social dessas empresas, sejam elas privadas, governamentais e até mesmo do terceiro setor. 


\begin{abstract}
In the discussions about environmental conservation and economic models in use nowadays, sustained development shows as a way to provide availability of natural resources, environmental protection and improvement of quality of life to several populations. In this scenario, tourism, one of the fastest growing economic activities, is a subject of studies about the sustainability of its activities. "Ecotourism" (Ecological tourism) seems to be an example of self-sustained economic activity. For ecotourism to be a viable solution, it is necessary that entrepreneurs, communities, nonprofit organizations, government and the population (as potential ecotourism consumers) learn its concepts and basic assumptions. Environmental education is the way to present this new activity. With an appropriate argumentation and adequate educational approach, it will be possible to inform, develop concepts and update common knowledge about environmental subjects. The goal of this work is to discuss the possibilities of creating public awareness about ecotourism by using external media, a tool that has unique characteristics and advantages due to its integration to natural environments - landscape - and its provocative integration to urban environments. To reach this objective, an integration of commercial activities related to ecotourism is suggested to reach the publicity market. By association of distinct activities in the ecotourism market, it may be possible to raise funds to make investments in these activities, who may be held by private companies, public companies or non-profit organizations.
\end{abstract}




\section{SUMÁRIO}

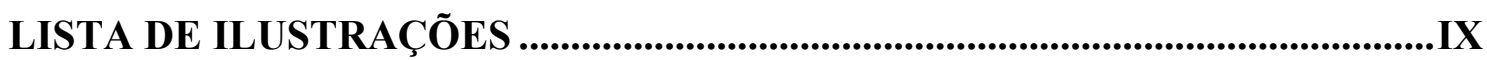

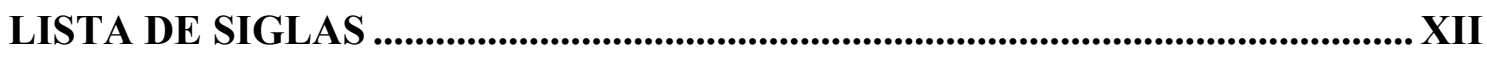

INTRODUÇÃ

CAPÍTULO 1 - REVISÃO DA LITERATURA..........................................................5

CAPÍTULO 2 - AS CARACTERÍSTICAS DA MÍDIA EXTERIOR E SUAS POSSIBILIDADES PARA A DIVULGAÇÃO, PROMOÇÃO E

FORTALECIMENTO DO ECOTURISMO.............................................................. 18

2.1 - INTEGRAÇÃO COM O AMBIENTE EXTERNO .................................................. 19

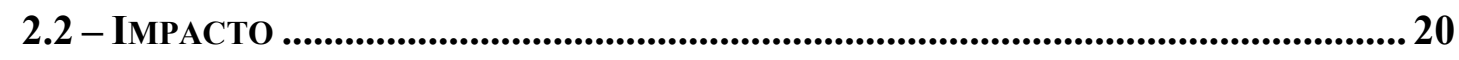

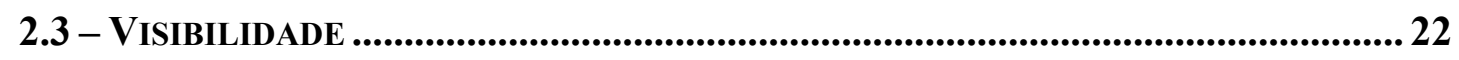

2.4 - FREQÜÊNCIA ININTERRUPTA................................................................................. 24

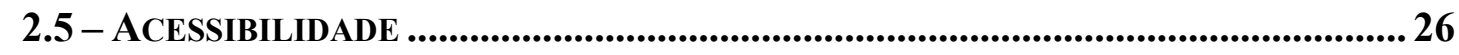

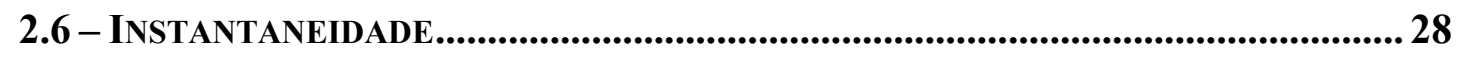

2.7 - Cobertura Abrangente e Segmentada ...............................................29

2.8 - Artefatos de Mídia EXTERior ................................................................... 31

2.9 - A MÍdIA VIVA .................................................................................... 44

CAPÍTULO 3 - O ECOTURISMO COMO ATIVIDADE ECONÔMICA SUSTENTÁVEL - CARACTERÍSTICAS E POSSIBILIDADES ............................. 46

CAPÍTULO 4 - A EDUCAÇÃO AMBIENTAL COMO LINGUAGEM E ARGUMENTO PARA A SENSIBILIZAÇÃO E CONQUISTA DO PÚBLICO PARA A PRÁTICA DO ECOTURISMO .................................................................. 49

CAPÍTULO 5 - A MÍDIA EXTERIOR COMO POSSIBILIDADE DE CRIAÇÃO DE CONSCIÊNCIA PÚBLICA SOBRE A PRÁTICA DO ECOTURISMO, ATRAVÉS DE PARCERIAS COM ENTIDADES AFINS NOS MESMOS INTERESSES MERCADOLÓGICOS DE ATUAÇÃO .............................................5 54

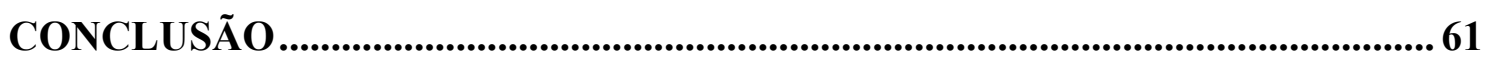

REFERÊNCIAS BIBLIOGRÁFICAS.....................................................................6 63

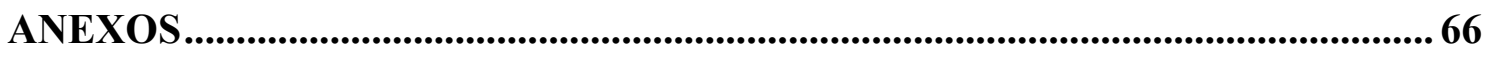




\section{LISTA DE ILUSTRAÇÕES}

Figura 1 - "Painel de endereçamento" - Possibilidade de sinergia com a paisagem natural

Figura 2 - "Back-Light" - Possibilidade de sinergia com a paisagem natural.

Figura 3 - "Front-Light" - Exemplo de educação ambiental / cívica, destacando espécie silvestre da região .......................................................................................... 8

Figura 4 - "Totem" - Exemplo de integração à paisagem urbana ..................................... 9

Figura 5 - "Ponto de Ônibus" - Exemplo de integração com a natureza, o fundo do painel se integra à paisagem natural ...................................................................9

Figura 6 - "Outdoor" - Exemplo de impacto na mensagem, com destaque visual...... 10

Figura 7 - "Campanha da Prefeitura de Belo Horizonte" - Exemplo de educação ambiental, provocando a parceria da comunidade .................................................... 11

Figura 8 - "Campanha da Fundação SOS Mata Atlântica "Eu vi o que você fez com a motossera" - Exemplo de impacto e conscientização 12

Figura 9 - "Dia do Meio Ambiente, EMBRATUR" - Exemplo de educação ambiental.. 13

Figura 10 - "Campanha de Turismo do governo de Pernambuco" - Exemplo do

interesse do estado em estimular o turismo 13

Figura 11 - “Anúncio Árvores" - Exemplo de marketing social de empresa privada 14

Figura 12 - "Anúncio Vale do Rio Doce" - Exemplo de marketing social 14

Figura 13 - "Anúncio Click Árvore" - Exemplo de parcerias do terceiro setor, empresas privadas e comunidade 15

Figura 14 - "Tabela crescimento mídia exterior" 18

Figura 15 - "Anúncio estrada" - Exemplo da importância de sinalização, possibilidade de interpretação ambiental. 19

Figura 16 - "Tabela pesquisa mídia exterior" 20

Figura 17 - "Fogo no Cerrado" - Exemplo de fotos chocantes para possível campanha de prevenção de incêndio. 21

Figura 18 - “Anúncio GDF” - Exemplo de campanha de prevenção e denuncio de incêndios.

Figura 19 - "Front-Light em área verde" - Possibilidade de campanha de Parques

Nacionais, com integração com paisagem natural - landscape 23

Figura 20 - "Barca em canal" - Possibilidade de campanha de águas despoluídas .... 24 
Figura 21 - "Campanha Nike" - Exemplo de campanha de educação ambiental ........ 25

Figura 22 - "Cachoeira de Bonito - MS" - Possibilidade de campanha de

interpretação ambiental com prevenção de perigos na natureza

Figura 23 - "Campanha do Pantanal" - Exemplo de campanha dirigida ao ecoturismo

Figura 24 - "Campanha Yashica" - Exemplo de campanha de empresa privada ao estímulo da prática ao ecoturismo

Figura 25 - "Rappel em Bonito - MS" - Exemplo de estímulo rápido. Imagem já desperta a curiosidade

Figura 26 - "Anúncio Faculdade Terra de Brasília" - Público dirigido.

Figura 27 - "Havaianas" - Exemplo de anúncio de calçados para a prática de esportes na natureza. Possibilidade de integração como landscape.

Figura 28 - "Outdoor em Brasília" - Campanha de estímulo à visitação ao Zôo de Brasília 32

Figura 29 - "Back-Light no Canadá"............................................................................... 32

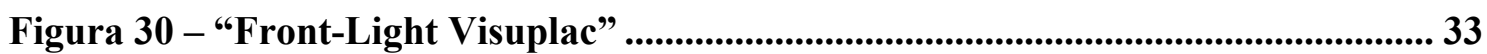

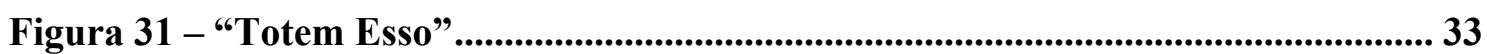

Figura 32 - "Relógio / Termômetro" ........................................................................... 34

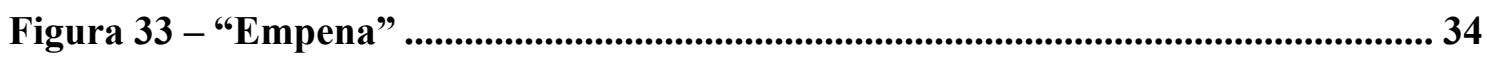

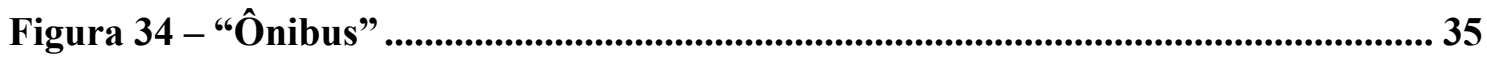

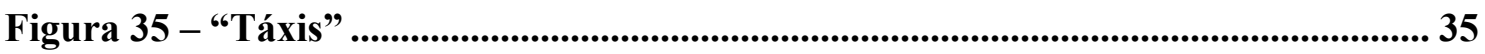

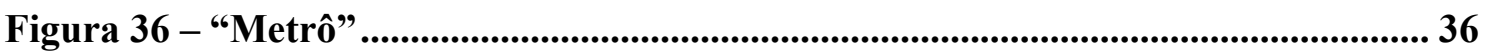

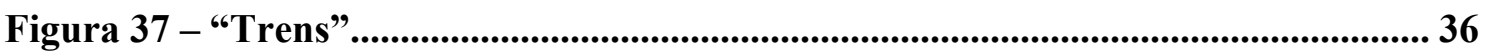

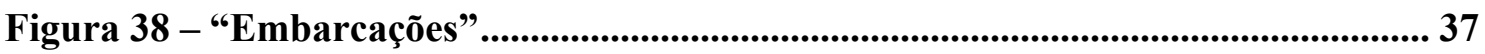

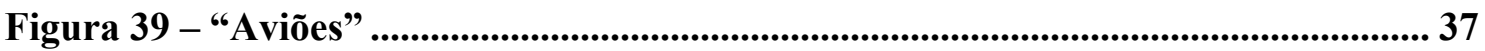

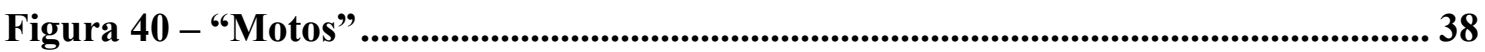

Figura 41 - "Abrigo de árvore" .................................................................................. 38

Figura 42 - "Faixas puxadas por aviões" ..................................................................... 39

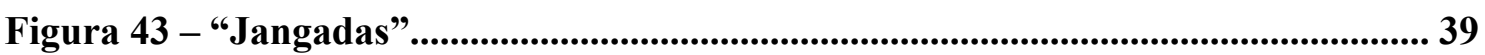

Figura 44 - "Painel de proteção para pedestre" "............................................................. 40

Figura 45 - "Pedágios" ................................................................................................ 40

Figura 46 - "Cabine telefônica" .................................................................................... 41

Figura 47 - "Back-Light Girafa" - Possibilidade de integração com a paisagem natural 
Figura 48 - "Front-Light Vivo" - Possibilidade de caracterização do engenho publicitário com o meio ambiente e com a mensagem .................................................. 42

Figura 49 - "Marvim, Samello e Zôo - Brasília" - Exemplos de apliques....................... 43

Figura 50 - “Anúncio HBO" - Exemplo de apliques "vivos" .......................................... 45

Figura 51 - "Anúncio reciclagem" "..............................................................................5

Figura 52 - “Anúncio Queimadas" .............................................................................. 51

Figura 53 - "Tamanduá" - Exemplo de linguagem simples e direta, com inspiração na

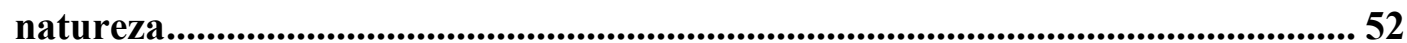

Figura 54 - "Peixes" - Exemplo de linguagem de impacto e direta .............................. 52

Figura 55 - "Tartaruga" - Exemplo de linguagem de impacto e direta ......................... 53

Figura 56 - "Campanha Terra Brasil" - Exemplo do interesse do governo federal em divulgar o turismo interno

Figura 57 - "Anúncio de artigos esportivos" - Exemplo do interesse de empresas privadas em estimular práticas esportivas ao ar livre 58

Figura 58 - "Anúncio VISA" - Exemplo do interesse em operadoras de cartões de crédito em estimular a prática do ecoturismo 59 


\section{LISTA DE SIGLAS}

CONAR

EA

EP

IBAMA

MMA

ONG

SEBRAE
- Conselho Nacional de Autor-Regulamentação Publicitária

- Educação Ambiental

- Escritório de Pesquisa

- Instituto Brasileiro de Meio Ambiente e dos Recursos

Naturais Renováveis

- Ministério do Meio Ambiente

- Organização Não Governamental

- Serviço Brasileiro de Apoio às Micro e Pequenas Empresas 


\section{INTRODUÇÃO}

Embora a expressão "ecoturismo" seja utilizada para caracterizar a modalidade de turismo em áreas naturais, cujas bases estão assentadas nas propostas de desenvolvimento sustentável, da conservação do patrimônio cultural e natural e da formação da educação ambiental, a sua prática tem demonstrado, no cotidiano, a ausência de uma ação mais efetiva em favor da consciência ambiental da população.

Os turistas continuam jogando lixo em locais inapropriados, quebrando galhos de árvores e coletando espécies da flora e da fauna em seus habitats naturais. Isso pode ser atribuído a dois fenômenos: a ausência de programas de educação e a interpretação ambiental e de instrumentos de conscientização pública sobre o uso sustentável dos recursos.

Este trabalho propõe-se a discutir as possibilidades de conscientização do público para o ecoturismo por meio da mídia exterior. A conscientização resulta de uma ação não necessariamente vinculada à educação formal, nas escolas. Pode ser fruto da educação ambiental, introduzida via meios de comunicação, agentes e difusores de mensagens, conteúdo e conceitos, além de grandes mobilizadores sociais.

A contribuição da mídia exterior, como meio de comunicação, para orientar a prática do ecoturismo é o objeto deste trabalho. Pretende-se estudar aqui especificamente o papel desempenhado por essa mídia.

Pesquisas do Instituto Datafolha, da Revista Meio \& Mensagem, da Revista Sinal Extensivo, da Central de Outdoor e do EP - Escritório de Pesquisa Eugênia Paesane, publicadas no Jornal Meio \& Mensagem de outubro de 2002, têm demonstrado que a mídia exterior apresenta propriedades e competências próprias devido as suas características estruturais e de localização, apresentando a flexibilidade de integração no lansdcape - paisagens naturais, e de funcionar provocativamente nas paisagens urbanas.

A mídia exterior possui grande visibilidade, impacto e abrangência na mensagem. Tem freqüência ininterrupta, pois permite a exposição continuada no dia-adia. É instantânea. É acessada por qualquer pessoa, não necessitando ser ligada ou 
comprada. Tem ampla cobertura, pois se pode escolher o local geográfico onde a mensagem é veiculada.

Apesar disso, tem sido modesto e de resultado duvidoso o uso da mídia exterior na área do meio ambiente, particularmente do turismo ecológico. Os indícios existentes, como o trabalho realizado pela empresa Farah Service, de São Paulo, que atua no segmento de marketing de responsabilidade social, promovendo o uso da mídia exterior na restauração de monumentos, na reurbanização de grandes avenidas, canteiros e jardins, são os de que a mídia exterior carrega consigo possibilidades e competências exclusivas.

Aplicadas ao ecoturismo, a mídia exterior poderia provocar impactos altamente favoráveis ao processo de conscientização pública sobre a prática do ecoturismo, tanto diretos - naquelas pessoas expostas às suas mensagens, quanto indiretos - pela incorporação de parceiros (empresas e indústrias) na sustentação de campanhas de responsabilidade social, voltadas para o ecoturismo.

Essas mesmas empresas estariam comprometidas com a sustentabilidade, até mesmo para melhorar a sua imagem institucional, perante os seus clientes diretos e o público em geral.

O ecoturismo, que pode operar como instrumento da educação e conscientização ambiental, reorientando atitudes e comportamento do público em relação à natureza, pode também incorporar produtivamente a questão da responsabilidade social, que envolve especialmente, neste trabalho, a pessoa jurídica.

A ausência de preocupações sobre o tema ecoturismo no ambiente do mercado publicitário demonstra que há um espaço vazio representado pela falta de debate, de preocupação e de trabalhos que envolvam esse tema. Faltam também informações sobre a sua conceituação politicamente correta, cuja base está assentada nos princípios da educação ambiental.

Ao situar essa questão dentro do espaço do Curso de Ecoturismo da UnB, a sua fragilidade emerge com muita clareza. Daí a preocupação deste trabalho em:

- identificar na mídia exterior as possibilidades de conscientização pública sobre o ecoturismo; 
- demonstrar que a mídia exterior pode contribuir para a consolidação e fortalecimento da prática do ecoturismo, por meios de linguagem publicitária (linguagem simples e direta), com conteúdo de educação ambiental;

- propor o uso da mídia exterior para a criação de consciência pública sobre a prática do ecoturismo, utilizando investimentos provenientes do marketing social de empresas que demonstrem interesse no mesmo mercado (público) do ecoturismo.

Para isso, foram feitas pesquisas bibliográficas, pesquisas documentais e análises sobre o crescimento da mídia exterior na cidade de Brasília, observando a partir do interior de empresa especializada no assunto - a Nova Mídia Visuplac.

Percebeu-se que esse meio de comunicação tem preenchido espaços abertos importantes e estratégicos, nas vias públicas e nos parques, veiculando mensagens publicitárias com características de grande impacto na comunicação, porém de integração duvidosa no landscape.

Foram analisadas pesquisas publicadas nos principais meios divulgadores do assunto comunicação/marketing/propaganda, como o objetivo de atualizar os dados sobre as características principais da mídia exterior, além de identificar, por meio de entrevistas, as tendências no mercado de agências de propaganda das principais capitais brasileiras, o que as mesmas pensam a respeito dessa mídia.

Utilizou-se para a coleta de dados a entrevista aberta semi-estruturada, por telefone, com os diretores de agências locais e de uma empresa de São Paulo. As entrevistas foram abertas e foi descrito neste trabalho apenas o resumo das mesmas.

Por entrevistas abertas semi-estruturadas entendemos ser aquelas em que o informante fala livremente sobre o tema proposto, limitado, contudo, por um roteiro de questões a serem pontuadas no momento da entrevista.

Essa abordagem é escolhida pelo fato de se considerar a fala, no dizer de MINAYO, como:

Reveladora de condições estruturais, de sistema de valores, normas e símbolos (sendo ela mesma um deles) e ao mesmo tempo ter a magia de transmitir através de um porta-voz, as representações de grupos determinados, em condições históricas, socioeconômicas e culturais específicas (MINAYO, 1992). 
O trabalho é desenvolvido em cinco capítulos:

No primeiro, discutem-se os conceitos de ecoturismo, de mídia exterior, de marketing social e de educação ambiental (estado da arte).

O segundo trata das características da mídia exterior e suas possibilidades para a divulgação, promoção e fortalecimento do ecoturismo.

No terceiro capítulo, o ecoturismo é apresentado como uma atividade econômica sustentável.

A educação ambiental, como linguagem e argumento para a sensibilização e conquista do público para a prática do ecoturismo, é discutida no quarto capítulo.

No capítulo quinto, é proposta a utilização da mídia exterior para a criação de consciência pública sobre a prática do ecoturismo, por meio de parcerias com empresas que tenham interesse nesse mesmo mercado de atuação. 


\section{CAPÍTULO 1 - REVISÃO DA LITERATURA}

O que significa o ecoturismo?

Mostrar-se-á, a seguir, algumas definições dadas ao termo "ecoturismo".

Segundo a definição da Embratur, ecoturismo é:

Um segmento da atividade turística que utiliza, de forma sustentável, o patrimônio natural e cultural, incentiva sua conservação e busca a formação de uma consciência ambientalista através da interpretação do ambiente, promovendo o bem-estar das populações envolvidas (EMBRATUR, 1994, p.19).

Já para Western ecoturismo significa:

A viagem responsável a áreas naturais, visando a preservar o meio ambiente e a promover o bem-estar da população local (FENNELL, 2002, p. 50, apud WESTERN, p. 17).

Goodwin assim define o termo ora estudado:

O turismo na natureza, de baixo impacto, que contribui à manutenção de espécies e habitats diretamente, por meio de uma contribuição à conservação e/ou indiretamente produzindo rendimentos para as comunidades locais, para que elas valorizem e, portanto, protejam suas áreas herdadas de vida selvagem como fonte de renda (FENNELL, 2002, p. 46, apud GOODWIN).

Segundo a definição de WALLACE \& PIERCE, o ecoturismo é:

A viagem a áreas naturais relativamente intocadas, para o estudo, o divertimento, ou a assistência voluntária. É a viagem em que há preocupação com a flora, a fauna, a geologia e os ecossistemas de uma área, assim como com as pessoas (guardiãs) que vivem nas vizinhanças, suas necessidades, sua cultura e seu relacionamento com a terra. $O$ ecoturismo encara as áreas naturais como "a casa de todos nós" num sentido global ("eco" significa "casa"), mas também especificamente a "casa dos habitantes das vizinhanças". Ele é visto como uma ferramenta para a conservação e o desenvolvimento sustentável - especificamente nas áreas onde a população local é solicitada a abrir mão do uso predatório dos recursos naturais em favor de outros tipos de uso (FENNELL, 2002, p. 49, apud WALLACE \& PIERCE, 1996, p.848).

Entende-se então que o ecoturismo é uma atividade econômica sustentável que, além de valorizar o patrimônio natural e cultural, estimula o conhecimento e a conservação das localidades visitadas, por meio de consciência ambiental, respeitando a comunidade local envolvida, no sentido de melhorar a sua qualidade de vida. 
É uma modalidade do turismo convencional que pretende provocar uma atitude diferenciada por parte do visitante em relação ao local visitado. Nesse sentido, o ecoturista não apenas irá usufruir desse ambiente, como atividade exclusiva de lazer e descanso, mas também deixará um mínimo de impacto sobre esse ambiente, assimilando mais conhecimentos sobre as características culturais / ambientais desse local e, por fim ampliará a sua sensibilidade com relação à natureza.

Essa atitude é despertada pela consciência ambientalista, consciência esta que tem inúmeras possibilidades de acontecer: no próprio local visitado, por meio da interpretação ambiental; nas escolas, por meio da educação formal; na mídia exterior, por meio de veiculação de mensagens conceituais de conscientização ambiental, de forma direta e instantânea, pelas suas características únicas de localização e formato.

O que significa a mídia exterior? Como não existe definição específica para a expressão "mídia exterior", toma-se emprestada a definição da palavra "outdoor", que o Novo Dicionário Aurélio da Língua Portuguesa prevê dois significados:

(1) Designação genérica de qualquer propaganda (painel, letreiro luminoso, parede pintada, etc.) exposta ao ar livre e que se caracteriza por forte apelo visual e comunicação instantânea. (2) Restritivamente, grande cartaz com essas qualidades, colocado no exterior, à margem das vias públicas, estradas ou em pontos de boa visibilidade.

No Dicionário de Comunicação de Rabaça \& Barbosa, outdoor:

É a designação genérica da propaganda feita ao ar livre. Literalmente (do inglês outdoor advertising), designa qualquer propaganda feita fora, exposta em via pública. Podemos distinguir vários tipos de outdoor (v. painel, cartaz, letreiro, luminoso, tabuleta, parede pintada, transporte, anúncio-sanduíche, over-lay, backlight), que apresentam, contudo, como características constantes, grande poder de comunicação, apelo visual e leitura instantânea, grandes dimensões, colocação em locais de boa visibilidade e onde transita intenso fluxo de pessoas (RABAÇA \& BARBOSA, 1987, p. 431).

Entende-se então que mídia exterior são todos os engenhos publicitários instalados ao ar livre, nas vias públicas ou em espaços privados, além de rodovias de acesso a entradas, com o fim de divulgar / expor marcas ou mensagens de campanhas publicitárias de um determinado produto ou serviço, mediante o pagamento de locação / aluguel do período predeterminado. 
As opções da mídia exterior ou propaganda ao ar livre se alteram constantemente e não se reduzem tão-somente aos tipos de outdoor citados na definição do Dicionário de Comunicação, anteriormente mencionado.

A pesquisa de materiais se multiplica com a tecnologia, gerando vários engenhos publicitários à disposição dos anunciantes. Muitos desses engenhos, inclusive, são conhecidos pelo nome comercial registrado pela empresa que o desenvolveu.

São muito variadas as opções de se anunciar em mídia exterior. O primeiro engenho deste tipo, e até hoje o mais conhecido e já citado, é o outdoor. Além deste, existem vários tipos de painéis, iluminados ou não, onde o anunciante de propaganda ao ar livre tem, a sua disposição, apenas para citar alguns: propaganda em ônibus, em metrôs, trens, embarcações e até mesmo em aviões, em relógios / termômetros, balões de gás, balões em lagos, oceanos ou piscinas, semáforos, lixeiras, painéis de proteção para pedestre, pontos de ônibus, painéis de endereçamento, faixas puxadas por aviões, totens, enfim, em qualquer elemento do chamado "mobiliário urbano", que possa ser visto por um número significativo de consumidores.

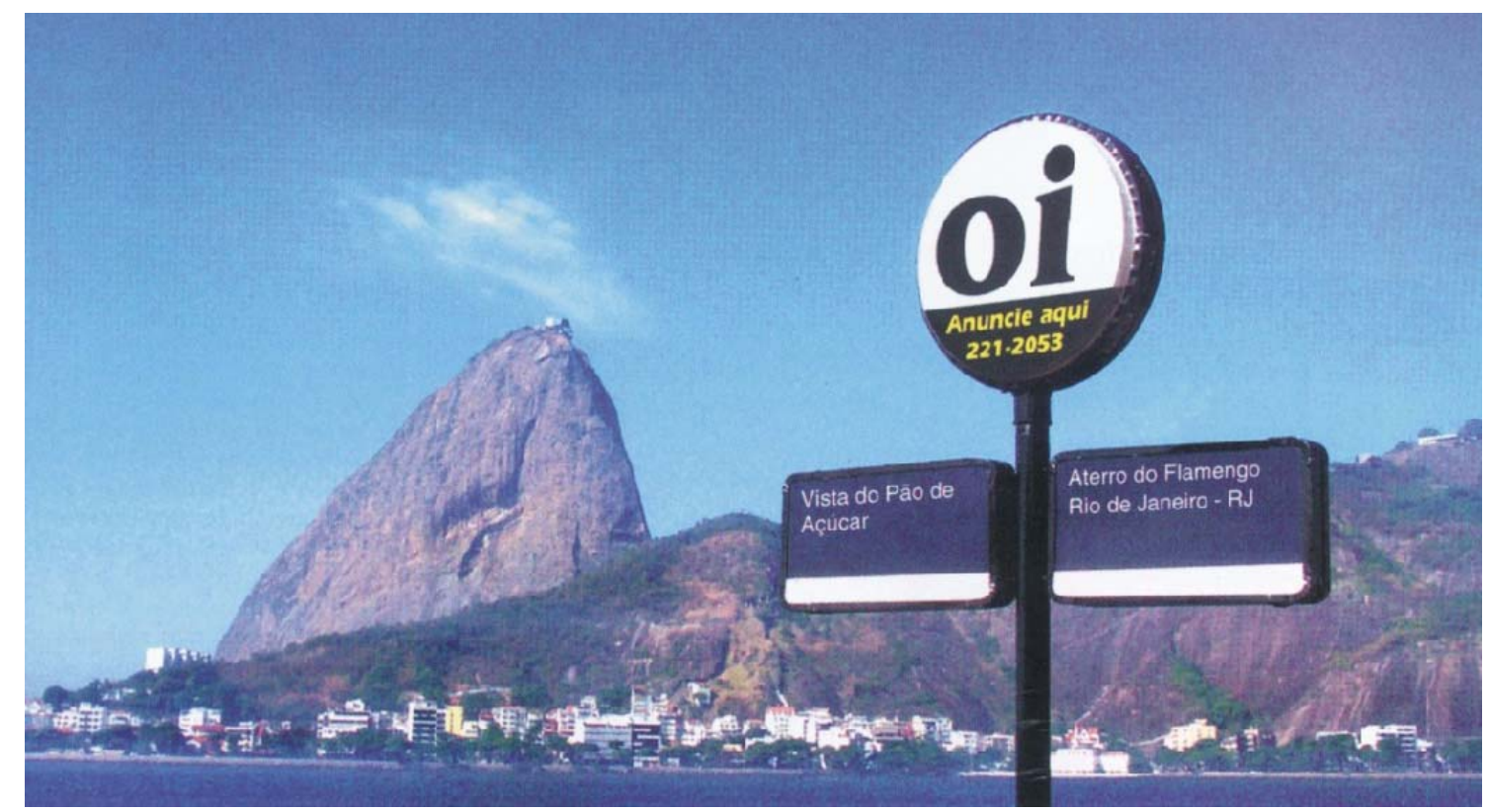

Figura 1 - "Painel de endereçamento" - Possibilidade de sinergia com a paisagem natural

Fonte: Revista Sinal Extensivo, Ano 4, n. 34, set 2000, p. 95, Mozarzel Edições e Promoções Ltda. 


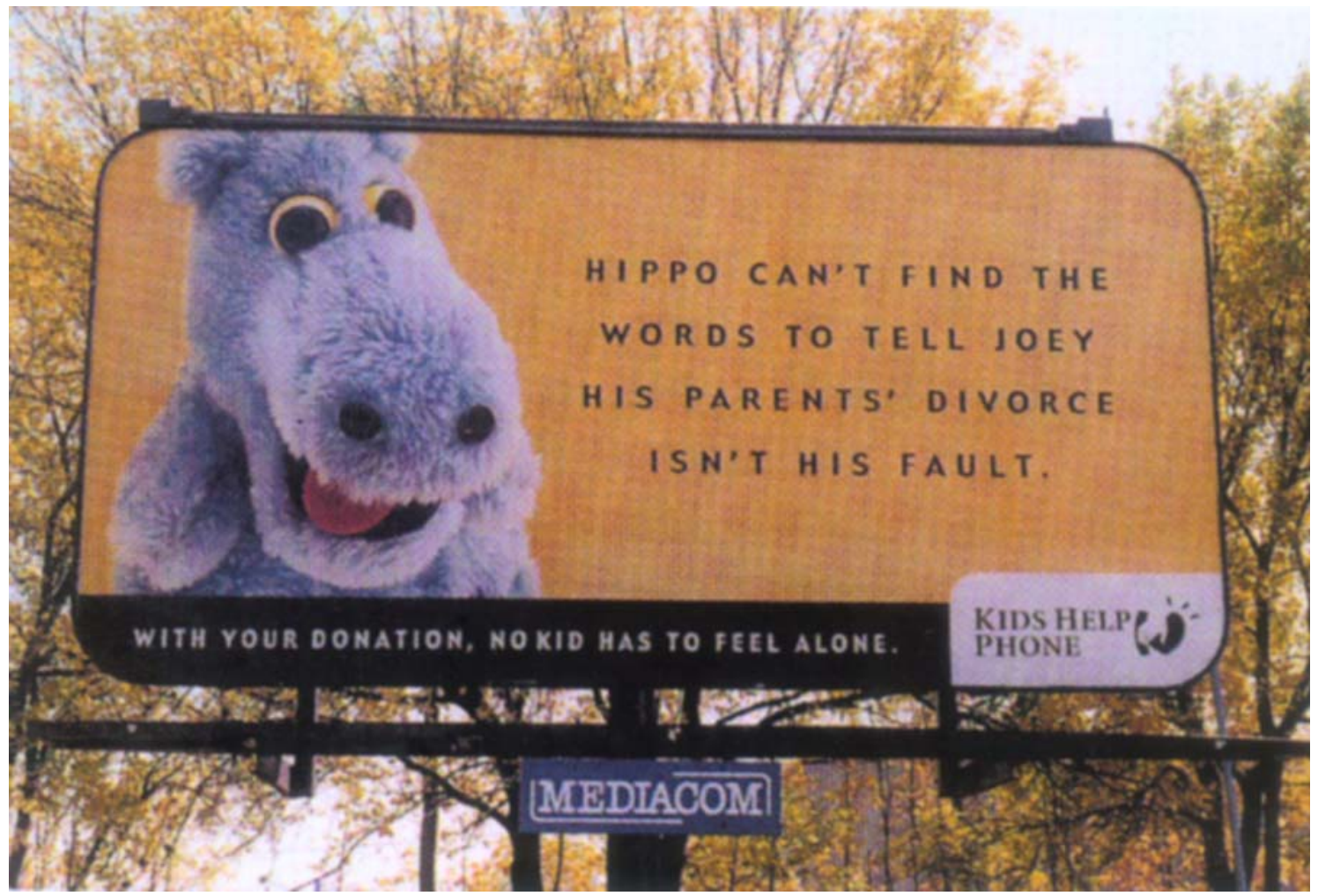

Figura 2 - "Back-Light" - Possibilidade de sinergia com a paisagem natural

Fonte: Revista Sinal Extensivo, Ano 4, n. 34, set 2000, p. 22, Mozarzel Edições e Promoções.

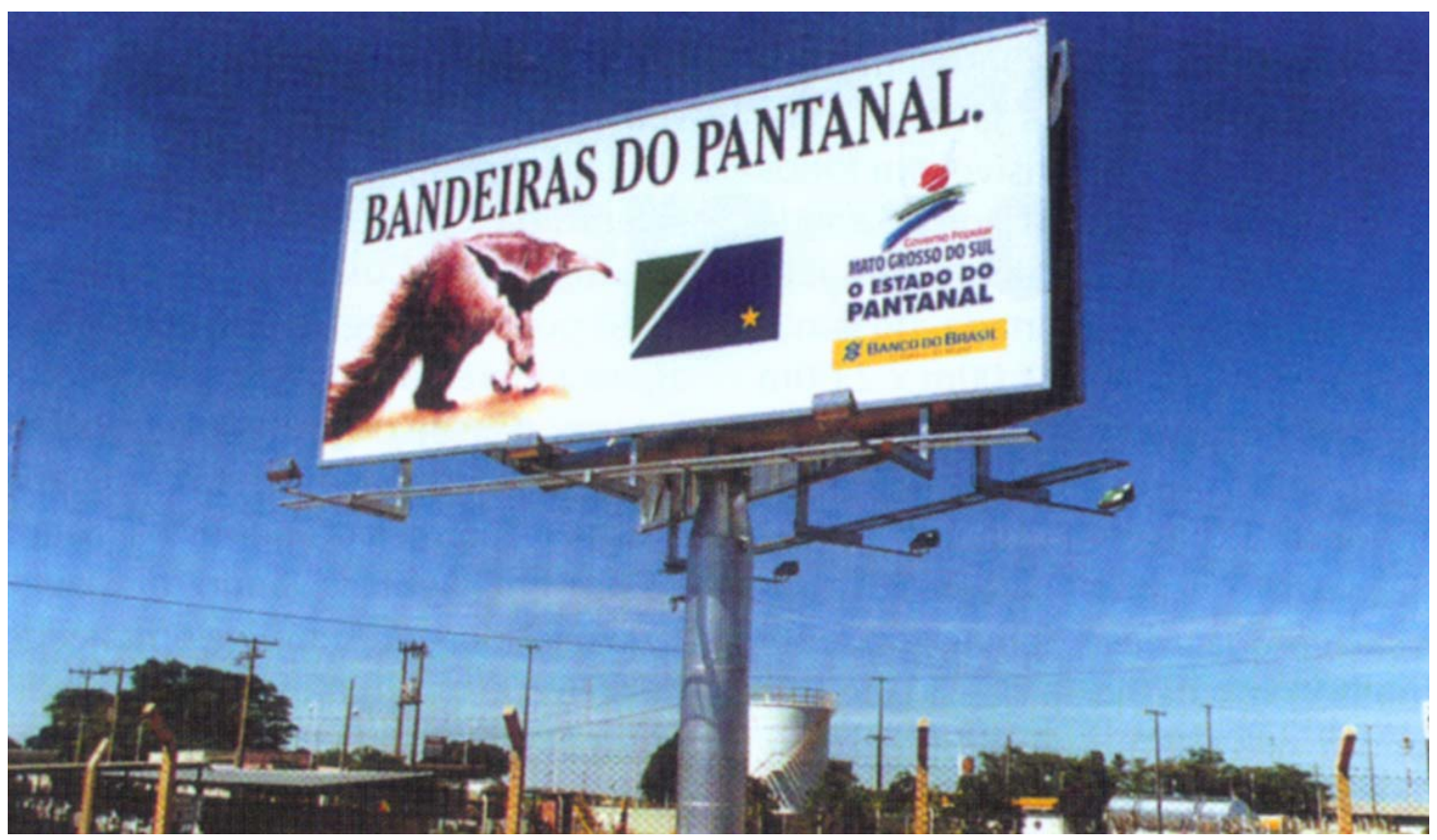

Figura 3 - "Front-Light" - Exemplo de educação ambiental / cívica, destacando espécie silvestre da região

Fonte: Revista Sinal Extensivo, Ano 4, n. 34, set 2000, p. 40, Mozarzel Edições e Promoções Ltda. 


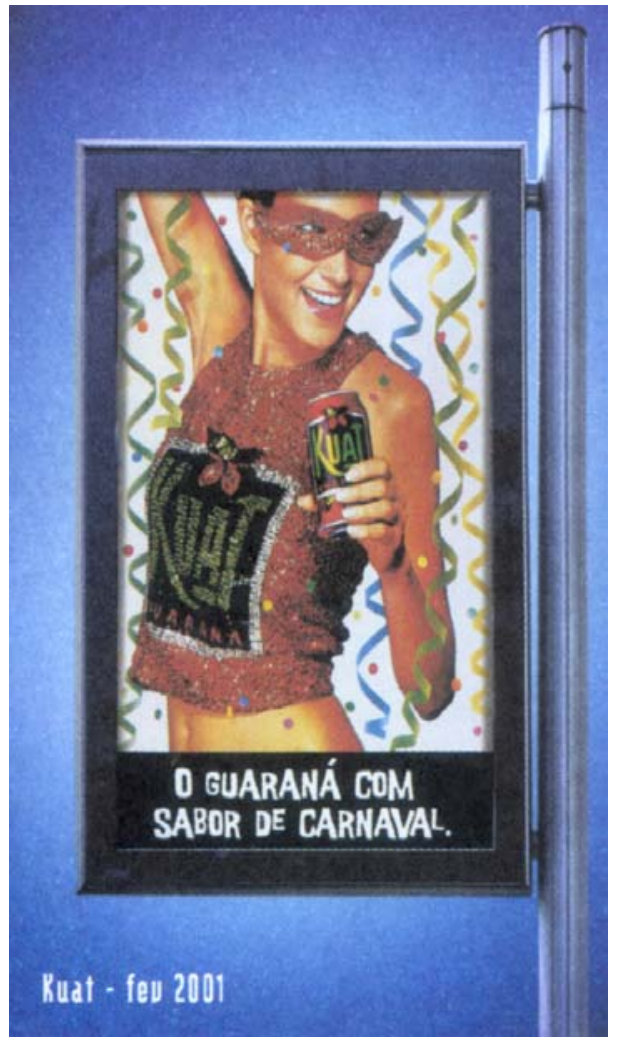

Figura 4 - "Totem" - Exemplo de integração à paisagem urbana

Fonte: Jornal Meio \& Mensagem, Edição Especial. Mídia Exterior, 19 mar. 2001, p. 15.

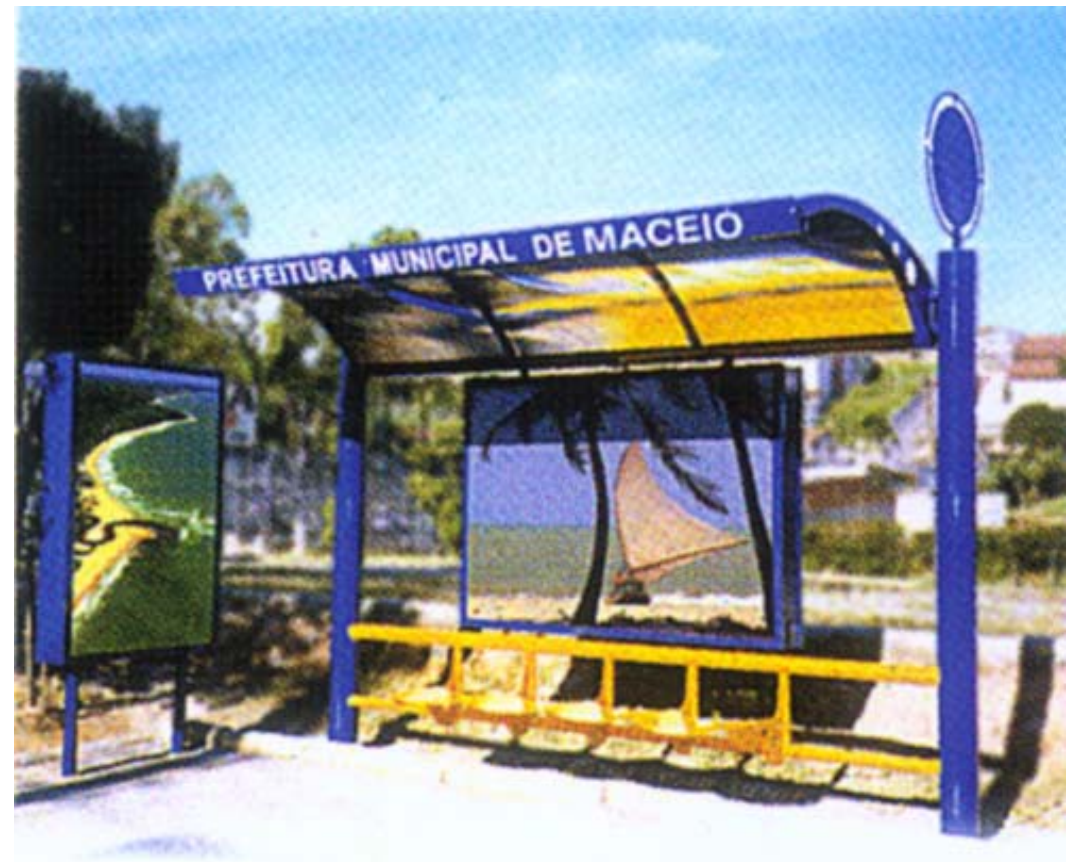

Figura 5 - "Ponto de Ônibus" - Exemplo de integração com a natureza, o fundo do painel se integra à paisagem natural

Fonte: Folder de Divulgação da empresa Mídia Plus, São Paulo. 

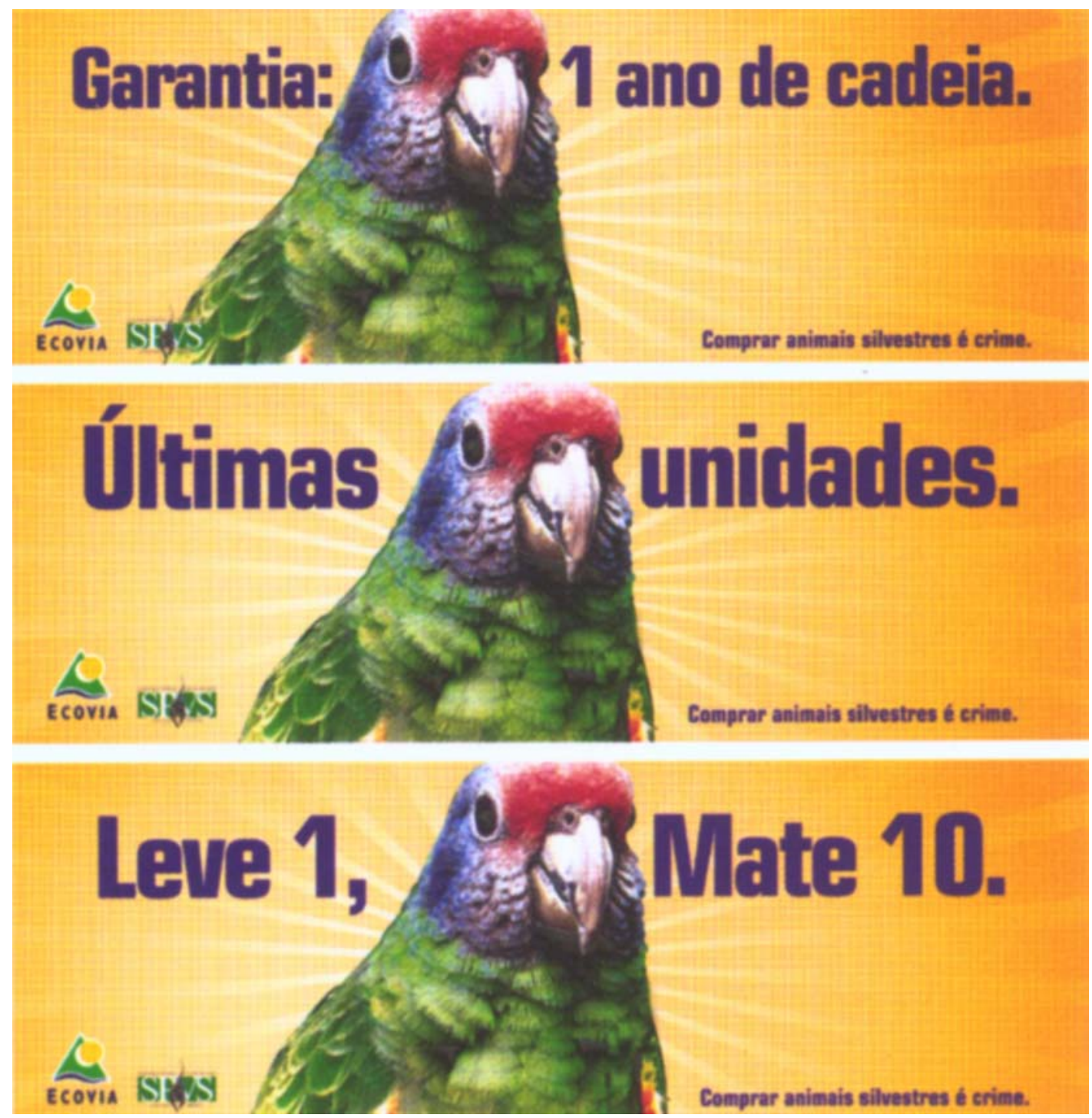

Figura 6 - "Outdoor" - Exemplo de impacto na mensagem, com destaque visual

Fonte: Revista About. Edição Especial. Portfolio, 2002/2003, p. 9, Versart Editora Artes e Comunicação Ltda.

Tudo isso é mídia exterior, ou propaganda ao ar livre.

A mídia exterior é a mídia acessível. Não necessita ser comprada, ligada ou folheada. Não é preciso adquirir financeiramente nenhum outro meio de comunicação para receber a mensagem, pois a mídia exterior está do lado de fora, nas ruas e estradas, no exterior das construções - outdoor.

Está integrada à paisagem - landscape -, de forma que suas estruturas procuram interagir com o meio, seja ele urbano ou não. 
A mídia exterior participa diretamente da paisagem urbana e, conseqüentemente, do cotidiano das pessoas. É instantânea. É vista e assimilada em segundos. De um momento para outro, pode-se cobrir toda uma cidade com mensagens previamente planejadas para um determinado objetivo. Por estar disponível a toda a população urbana, torna-se uma mídia indistinta e, ao mesmo tempo, compulsória, trazendo consigo uma imensa responsabilidade social.

Segundo a Central de Outdoor, uma instituição de natureza civil, sem fins lucrativos, até o momento não ocorreu nenhum tipo de problema entre o CONAR Conselho Nacional de Auto-Regulamentação Publicitária, e uma mensagem de propaganda veiculada nesse meio.

Por sua característica de localização, é possível atingir segmentos específicos da população, na medida em que se pode escolher o local geográfico e os roteiros específicos onde a mensagem será veiculada.
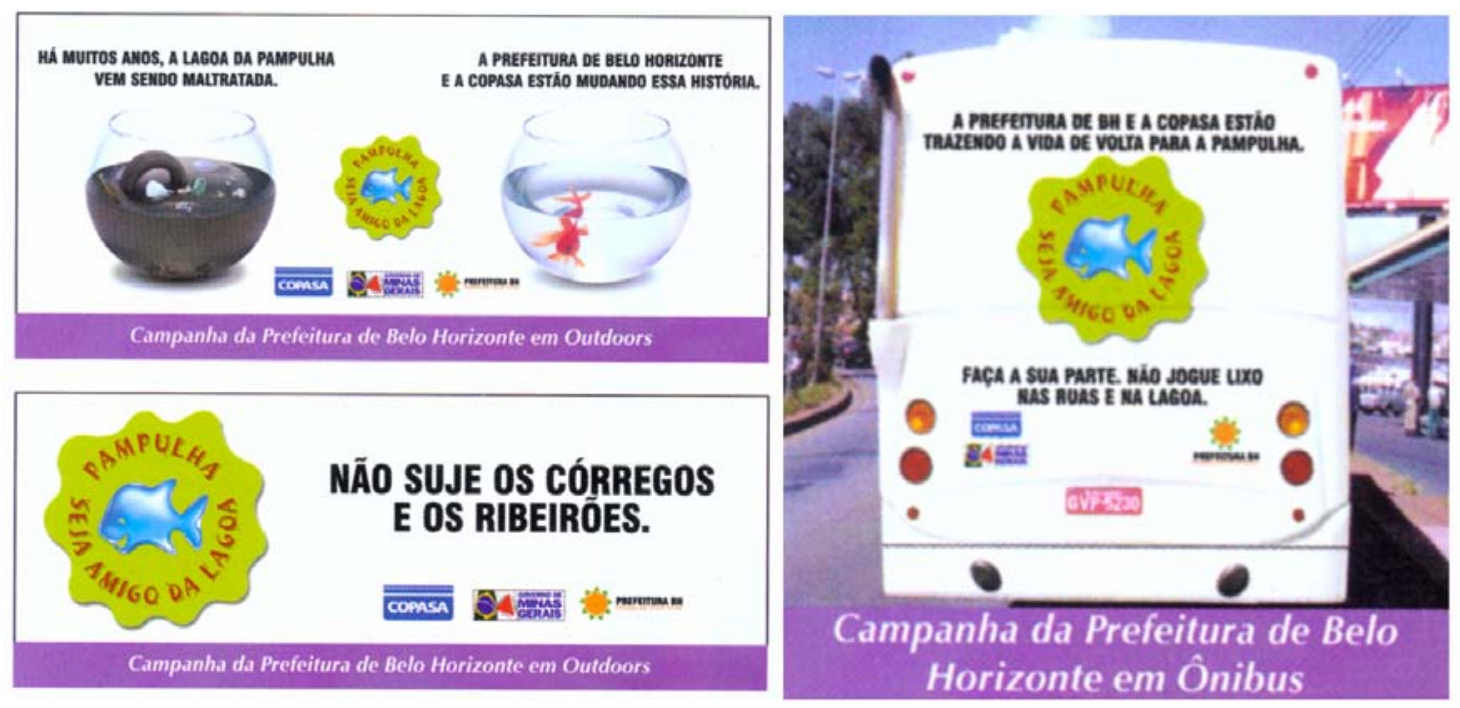

Figura 7 - "Campanha da Prefeitura de Belo Horizonte" - Exemplo de educação ambiental, provocando a parceria da comunidade

Fonte: Revista Sinal Extensivo, Ano 7, n. 59, jan. 2003, p. 16, Mozarzel Edições e Promoções Ltda.

É constante e intermitente. Está "no ar" 24 horas por dia, durante o período que for contratado - desde 15 dias até mesmo durante um ou mais anos ininterruptos. É uma das formas mais eficientes e rápidas de se manifestar o tema de uma campanha, devido às suas características de grande visibilidade, objetividade, simplicidade e alcance. 
Aliada ao ecoturismo, a mídia exterior pode sugerir à população urbana, de forma extremamente direta e simples, conceitos de interpretação e educação ambiental, motivando-a a valorizar atitudes simples, como a prevenção de incêndios nos campos e nas próprias cidades, a economizar ou usar sem desperdício a água, a energia, o papel e demais recursos naturais.
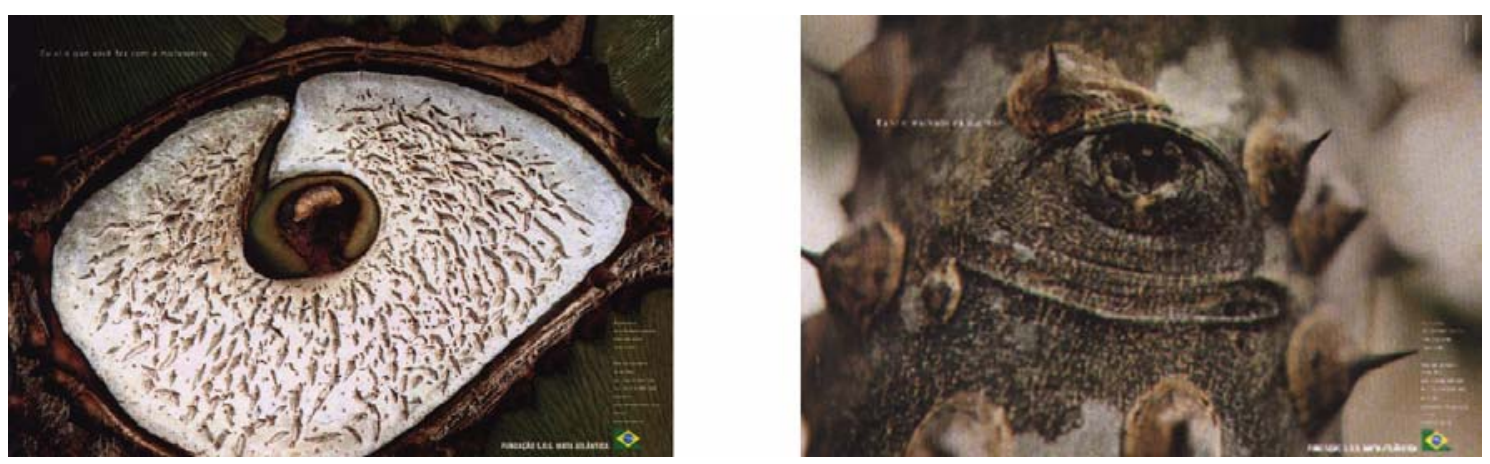

Figura 8 - "Campanha da Fundação SOS Mata Atlântica "Eu vi o que você fez com a motossera" - Exemplo de impacto e conscientização

Fonte: Prêmio Folha. Revista da Criação de Publicidade, São Paulo, 2001, p. 169.

É buscada também a valorização da natureza, de forma prática, motivando a visita ao campo, aos Parques Nacionais, muitas vezes próximos de centros urbanos, porém visitados por multidões de outras localidades que não as da própria localidade ou próximas a ela.

Objetiva-se também motivar a mudança de postura em manter limpas as cidades, lagos, rios e campos, principalmente sugerir hábitos de consumo e comportamento, de forma positiva, dando sugestões de como fazer, e explicando o porquê dessas ações, não simplesmente dizendo "não suje, não jogue, não pegue" e, se for necessário dizer isso, explicar também de que maneira isso é prejudicial à natureza e à própria humanidade. 


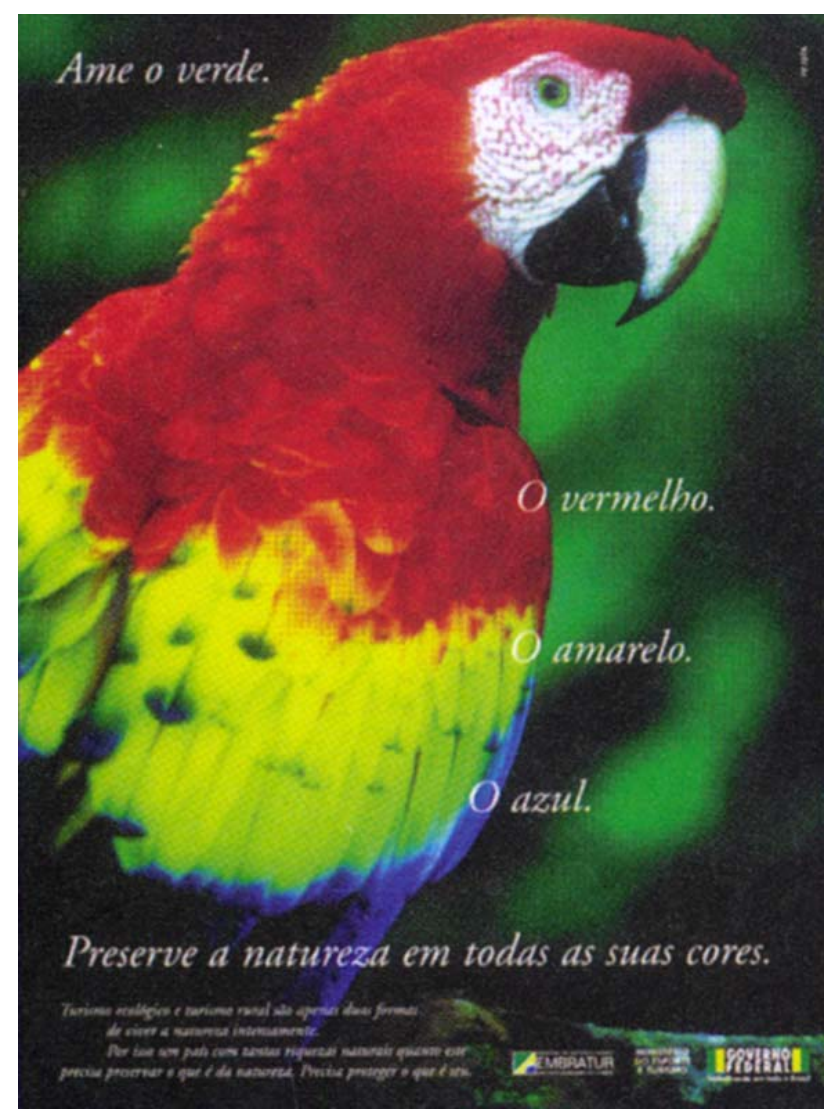

Figura 9 - "Dia do Meio Ambiente, EMBRATUR" - Exemplo de educação ambiental

Fonte: Revista About. Edição Especial. Portfolio, 2002/2003, p. 67, Versart Editora Artes e Comunicação Ltda.

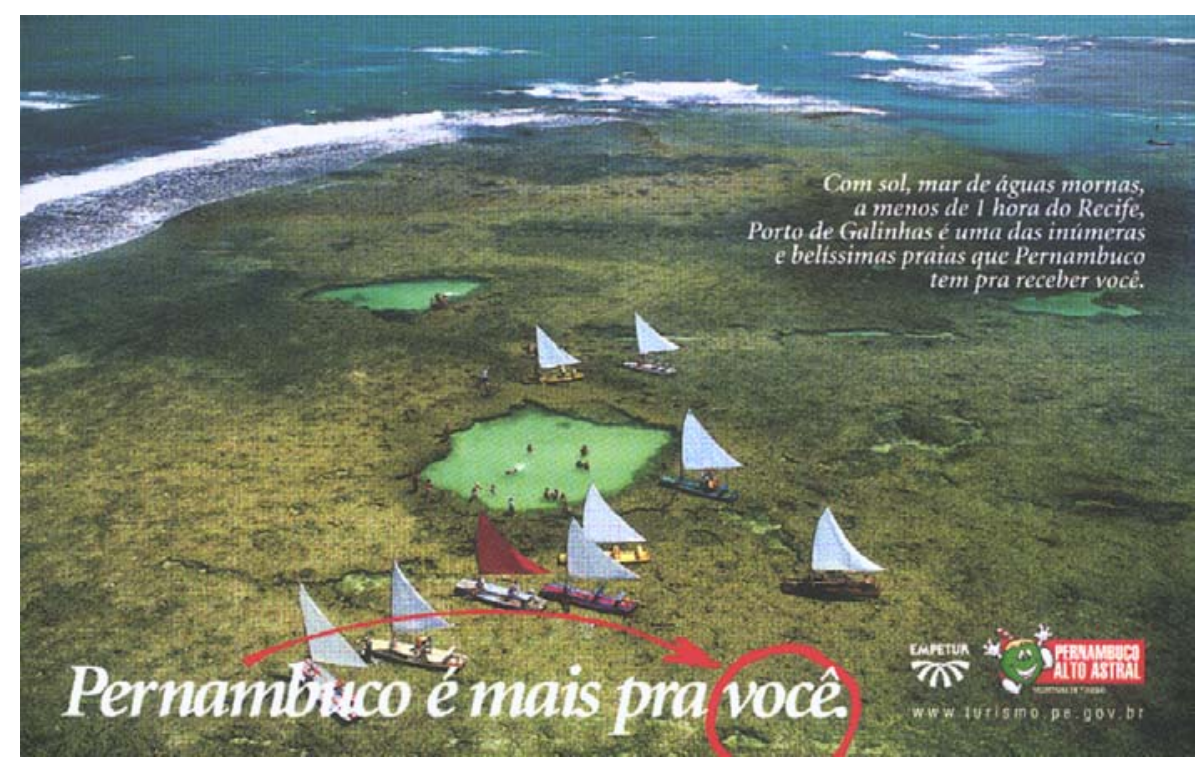

Figura 10 - "Campanha de Turismo do governo de Pernambuco" - Exemplo do interesse do estado em estimular o turismo

Fonte: Revista About. Edição Especial. Portfolio, 2002/2003, p. 47, Versart Editora Artes e Comunicação Ltda. 


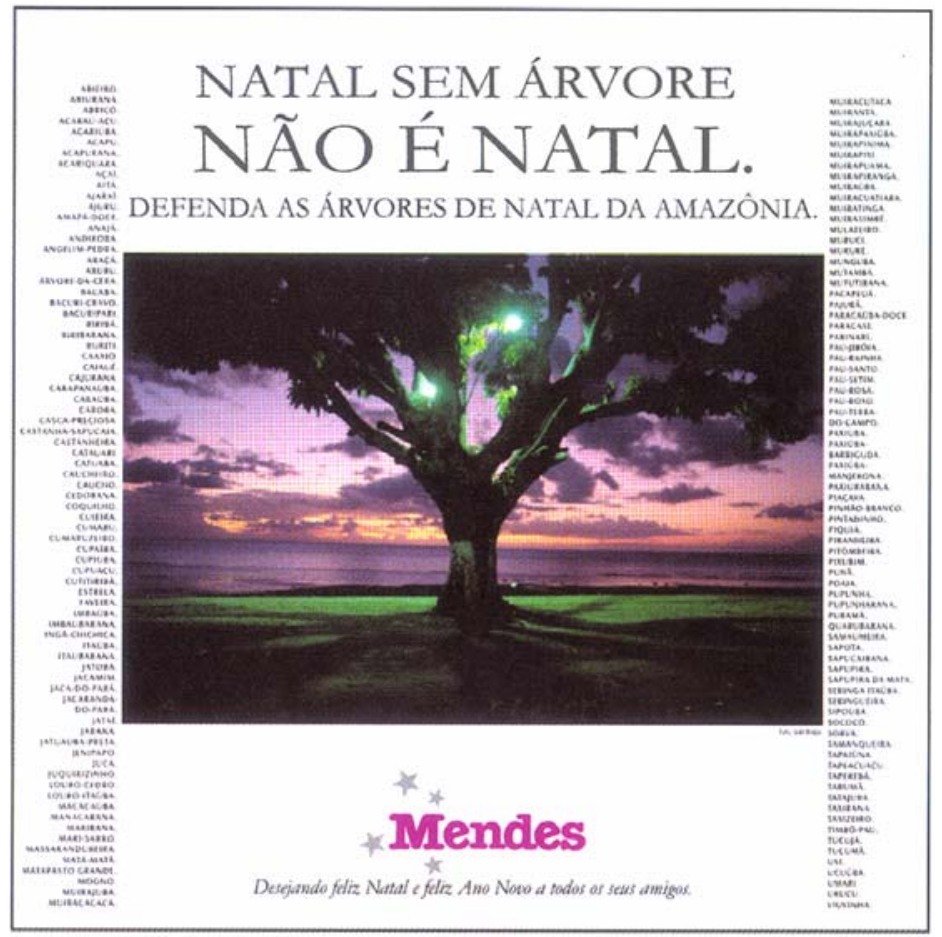

Figura 11 - "Anúncio Árvores" - Exemplo de marketing social de empresa privada

Fonte: Revista About. Edição Especial. Portfolio, 2002/2003, p. 61, Versart Editora Artes e Comunicação Ltda.

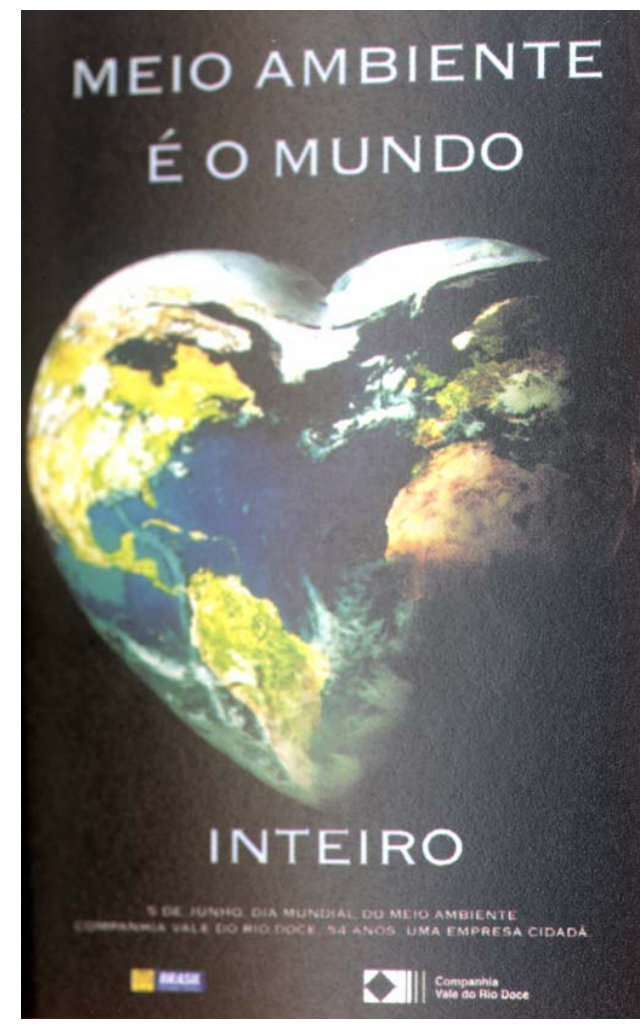

Figura 12 - “Anúncio Vale do Rio Doce" - Exemplo de marketing social

Fonte: Revista About. Edição Especial. Portfolio, 2002/2003, p. 23, Versart Editora Artes e Comunicação Ltda. 


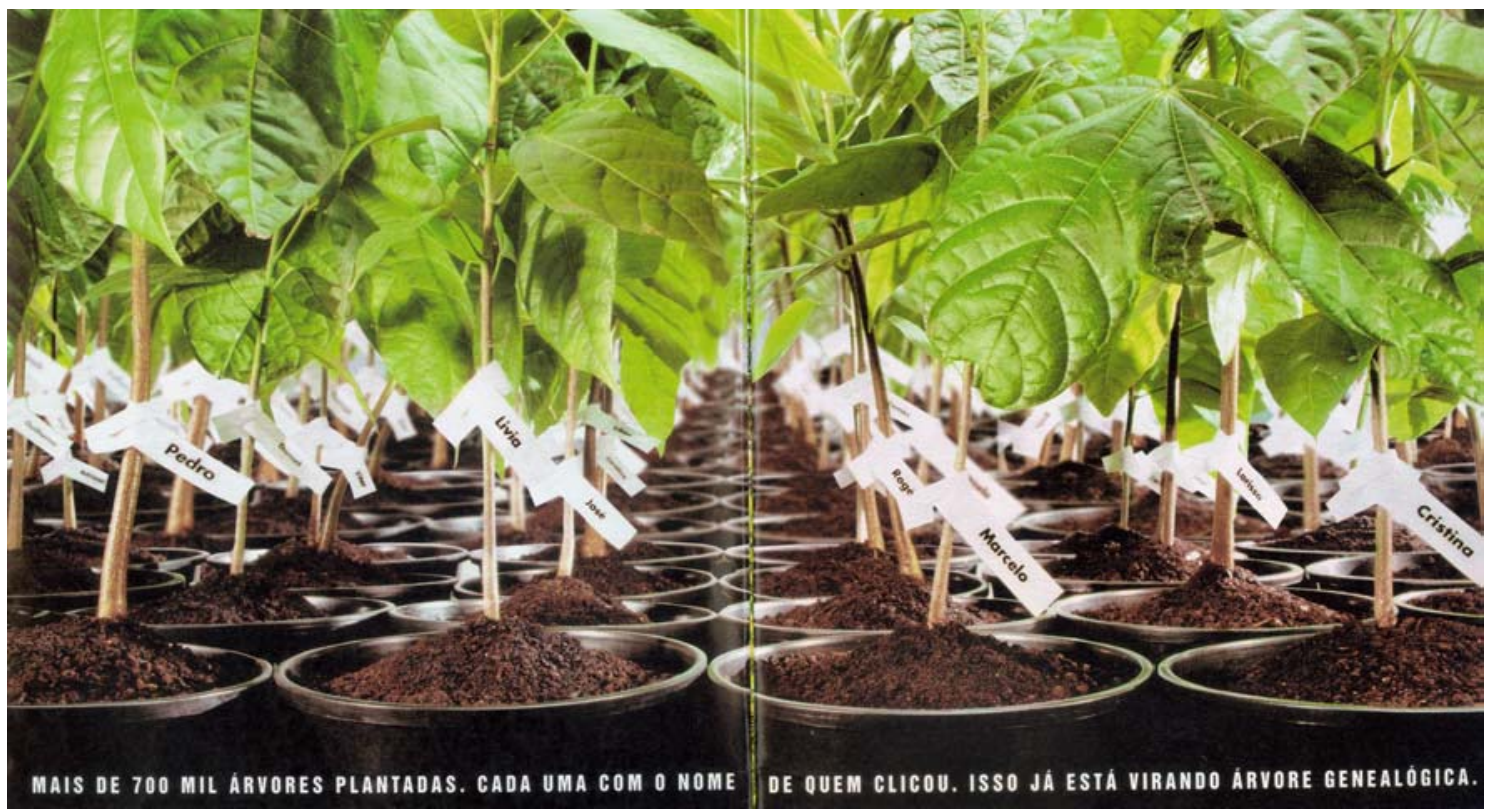

Figura 13 - "Anúncio Click Árvore" - Exemplo de parcerias do terceiro setor, empresas privadas e comunidade

Fonte: Revista Veja, ano 35, n. 22, Edição Especial Ecologia, dez. 2002, Editora Abril.

O que significa, portanto, marketing social?

Segundo o entendimento de Vaz:

Marketing social é a modalidade de ação mercadológica institucional que tem como objetivo principal atenuar ou eliminar os problemas sociais, as carências da sociedade relacionadas principalmente às questões de higiene e saúde pública, de trabalho, educação, habitação, transportes e nutrição (VAZ, 1995, p. 280).

Para Kozel Júnior, o marketing social tem o seguinte significado:

Cria e administra todo o processo, cujas ações e resultados passam a construir valores que se agregam aos produtos. $O$ assistencialismo, mesmo se efetuado de forma sistemática, pouco agrega ao conceito da empresa, pois ela não gerencia nem detém a autoria e o controle do processo (KOZEL JÚNIOR, 1997, p. 214).

Para Kotler \& Roberto:

Marketing social é uma estratégia de mudança de comportamento. Ele combina os melhores elementos das abordagens tradicionais da mudança social num esquema integrado de planejamento e ação, além de aproveitar os avanços na tecnologia das comunicações e na capacidade de marketing (KOTLER \& ROBERTO, 1992, p. 25).

Num momento em que as empresas começam a despertar para o marketing social, encarando-o não somente como um ônus a mais, mas como um investimento 
social, resultando em lucros econômicos tangíveis para toda a sociedade, está clara a oportunidade de que o ecoturismo, como atividade econômica sustentável que se propõe, pode utilizar a mídia exterior, por meio das suas características de grande visibilidade, exposição, impacto e alcance, para se tornar a ferramenta / parceira do processo de informação e formação de consciência ambiental.

Somando-se a isso, a pré-disposição de várias das grandes e médias empresas privadas, em colaborar com assuntos sociais e ao mesmo tempo melhorar a sua imagem institucional perante o público, ao mesmo tempo sabendo estar cumprindo um papel social e prevenindo para a obtenção de uma situação de melhoria econômica da sociedade, que certamente vai reverter em benefício dessas mesmas instituições, as quais pretendem continuar comercializando seus produtos / serviços às pessoas, no futuro.

É o que relatam Kotler \& Roberto:

O desafio e o objetivo do marketing social é gerar mudança social para a melhoria de vida (KOTLER \& ROBERTO, 1992, p. 1).

O que significa educação ambiental? A definição legal, segundo o artigo $1^{\circ}$ da Lei Federal no 9.795, de 27/4/99, é a seguinte:

Art. $1^{\circ}$. Os processos por meio dos quais o indivíduo e a coletividade constroem valores sociais, conhecimentos, habilidades, atitudes e competências voltadas para a conservação do meio ambiente, bem de uso comum do povo, essencial à sadia qualidade de vida e sua sustentabilidade.

Segundo Santos, a doutrina é:

O processo educacional de estudos e aprendizagem dos problemas ambientais e suas interligações com o homem na busca de soluções que visem a preservação do meio ambiente (SANTOS, Jornal A Tribuna, 31 maio 1999).

A Constituição Federal de 1988 traz, em seu Capítulo VI - Do Meio Ambiente, no artigo 225, o seguinte:

Todos têm direito ao meio ambiente ecologicamente equilibrado, bem de uso comum do povo e essencial à sadia qualidade de vida, impondo-se ao Poder Público e à coletividade o dever de defendê-lo e preservá-lo para as presentes e futuras gerações.

O primeiro conceito de Educação Ambiental - EA, surgiu na Conferência de Estocolmo, em 1972. Esse conceito foi sofrendo modificações nos Encontros de 
Belgrado (1975), de Tibilisi (1977), do Rio de Janeiro (1992), e de Tessalonique, na Grécia (1997).

Nessa última conferência internacional, foram citadas várias recomendações, dentre as quais destaca-se a seguir:

As instituições financiadoras, governos nacionais, internacionais e regionais, assim como os setores produtivos, devem ser impulsionados para realizar pesquisas adicionais $e$ incrementar os recursos para a educação e conscientização pública.

A mídia deve ser sensibilizada e convidada a mobilizar seu know-how em canais de distribuição, para difundir mensagens-chave, enquanto auxilia na tradução dos itens complexos para o melhor entendimento do público.

A educação ambiental torna-se então um instrumento fundamental no processo de sensibilização da opinião pública, para as atitudes de comportamento que prevê a Constituição Federal ao equilíbrio ecológico do meio ambiente.

$\mathrm{O}$ ecoturismo traz consigo a mesma premissa que remete ao desenvolvimento sustentável, o qual "satisfaz as necessidades do presente sem comprometer a capacidade das futuras gerações de satisfazerem as suas" (Relatório Brundland, apresentado na Comissão Mundial de Meio Ambiente e Desenvolvimento das Nações Unidas, 1987).

Conforme as recomendações de Tessalonique, citadas anteriormente, entende-se que a mídia exterior é uma ferramenta estratégica para mobilizar, sensibilizar e traduzir, de forma simples, para o público - com o apoio da criação publicitária -, as mensagens de educação ambiental para a conservação e equilíbrio ecológico que o ecoturismo prevê. 


\section{CAPÍTULO 2 - AS CARACTERÍSTICAS DA MÍDIA EXTERIOR E SUAS POSSIBILIDADES PARA A DIVULGAÇÃO, PROMOÇÃO E FORTALECIMENTO DO ECOTURISMO}

Conforme pesquisas do Instituto Datafolha, da Revista Meio \& Mensagem, da Revista Sinal Extensivo, da Central de Outdoor e do EP - Escritório de Pesquisa Eugênia Paesane, a mídia exterior apresenta propriedades e competências próprias de comunicação, devido às suas características de estrutura e de localização.

Segundo as pesquisas mencionadas, essas características garantem o sucesso na divulgação, fortalecimento e consolidação de marcas e conceitos, comprovados pelo crescimento nos investimentos nessa mídia em relação ao crescimento de outros veículos de comunicação.

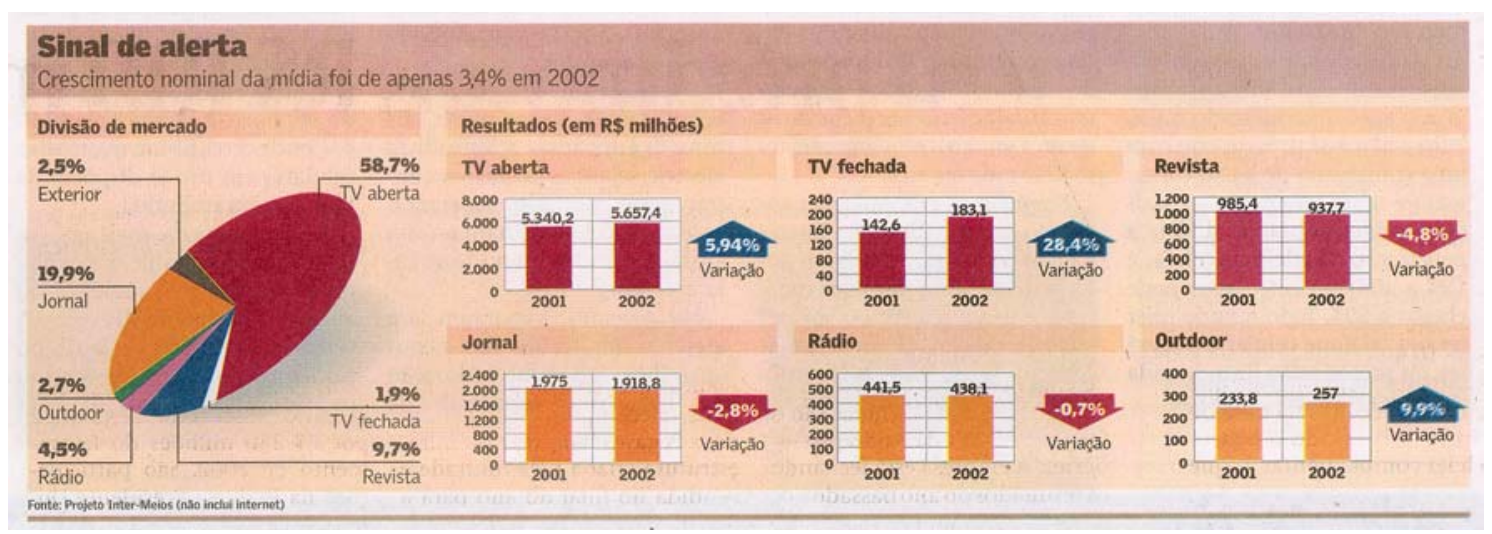

Figura 14 - "Tabela crescimento mídia exterior"

Fonte: Jornal Valor Econômico, B3, 10 mar. 2003.

Entende-se que a mídia exterior, integrada ao meio externo e utilizando-se da linguagem da educação ambiental, tem como possibilidade e desafio sensibilizar a consciência pública para a prática do ecoturismo. Para isso, receberia os investimentos em marketing social, de empresas interessadas neste mesmo segmento de mercado, do ecoturismo como, por exemplo, indústrias de material esportivo ou camping.

Por meio dessa sensibilização de consciência pública para a prática do ecoturismo, a mídia exterior poderá contribuir para a geração de mudança social, visando uma melhoria na qualidade de vida das populações. 


\section{1 - INTEGRAÇÃO COM O AMBIENTE EXTERNO}

A principal característica dessa mídia, com relação ao benefício ao ecoturismo, é o lansdcape, (paisagem, horizonte), ou seja, a sua localização é inserida junto a paisagens abertas, ao horizonte, nos espaços vazios, sejam paisagens naturais ou urbanas, ou nas duas ao mesmo tempo.

\section{FARIA relata:}

Ler a paisagem é muito mais complexo do que ver e perceber a paisagem. Envolve uma visão do mundo, consciente e inconsciente, sempre subjetiva e permeada pelo imaginário (FARIA, 1997, p. 37).

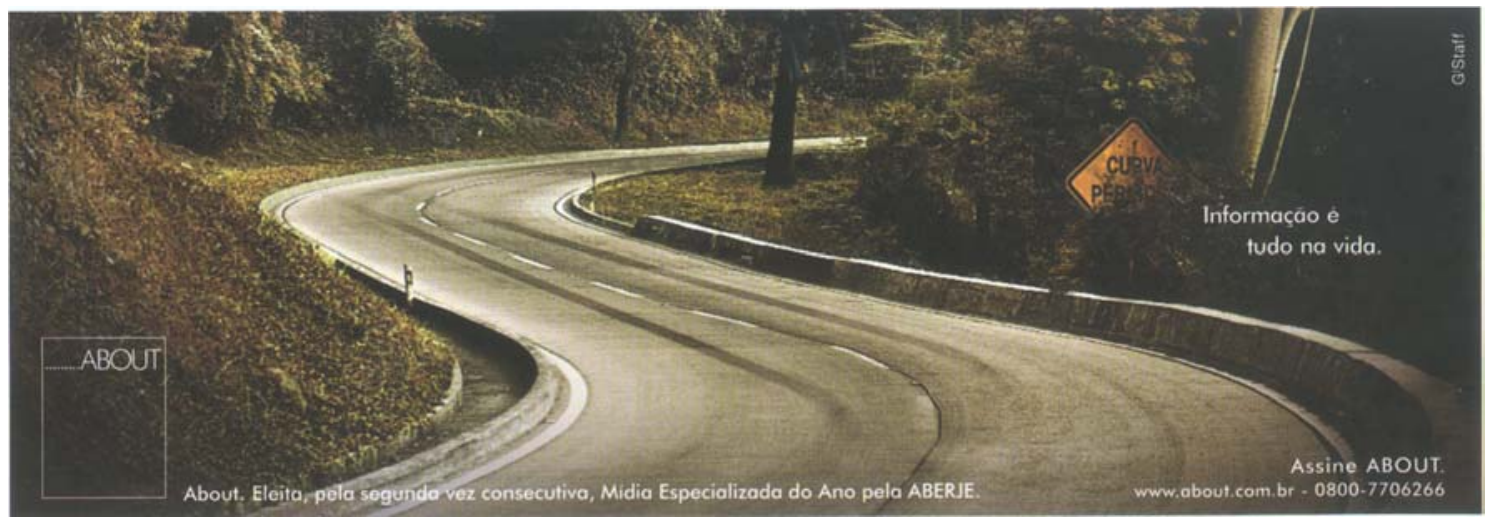

Figura 15 - “Anúncio estrada” - Exemplo da importância de sinalização, possibilidade de interpretação ambiental

Fonte: Revista About. Edição Especial. Portfolio, 2002/2003, p. 44/45, Versart Editora Artes e Comunicação Ltda.

Pelo fato de estar instalada nesses espaços abertos, podendo ser junto ao verde, à terra, às águas, aos céus, mas sempre às margens das vias públicas ou estradas, a mídia exterior, como a própria expressão já diz, é uma mídia totalmente exposta ao ar livre, de dia e de noite.

Essa exposição permite-lhe uma aproximação junto ao público, que também está nesse mesmo espaço aberto, trabalhando, deslocando-se, divertindo-se e até mesmo descansando.

Aproveitando essa característica de integração com a paisagem aberta e a proximidade com o público das cidades, a mídia exterior tem a possibilidade de ser utilizada para veicular mensagens que promovem e fortalecem o ecoturismo, traduzindo 
conceitos de educação ambiental, por meio de linguagem publicitária, cujas mensagens são diretas, objetivas e de fácil entendimento.

\section{2 - IMPACTO}

Segundo pesquisa realizada pelo EP - Escritório de Pesquisa Eugênia Paesane, junto aos profissionais das agências de propaganda, sempre que um produto, serviço ou conceito necessita ser anunciado com uma grande dose de impacto, a mídia exterior é o meio escolhido.

Sendo um meio que participa diretamente da paisagem urbana (e, conseqüentemente, do quotidiano das pessoas) e com proporções ampliadas, o que na maioria dos casos possui, a mídia exterior está sempre diretamente relacionada com o conceito de impacto na comunicação.

\section{As principais vantagens dos veículos de mídia exterior}

Visibilidade e impacto da mensagem

Abrangência da mensagem

Exposição continuada no dia-a-dia

Possibilidade de segmentação

Melhor custo/benefício

Oportunidade de criação

Maior permanência da campanha

Agilidade de negociação

É utilitária (p. ex. abrigo de ponto de ônibus)
Todas as cidades (\%)

74

45

18

18

16

13

10

3

2
Outras cidades (\%) São Paulo (\%) 77

46

23

17

8

10

8

4

71

44

13

19

25

17

13

2

4

Figura 16 - "Tabela pesquisa mídia exterior"

Fonte: Jornal Meio \& Mensagem. Edição Especial. Mídia Exterior, p. 8, 14 out. 2002.

Nesse sentido, entende-se que quando o assunto abordado em uma campanha de indústria de botas para caminhada (trekking), por exemplo, for a prevenção de queimadas, grandes painéis de estrada serão perfeitamente apropriados para esse fim, uma vez que estarão localizados no ponto crítico onde podem ocorrer incêndios provocados por motoristas e passageiros, que jogam pontas de cigarro ou mesmo objetos diversos pela janela de seus veículos. 

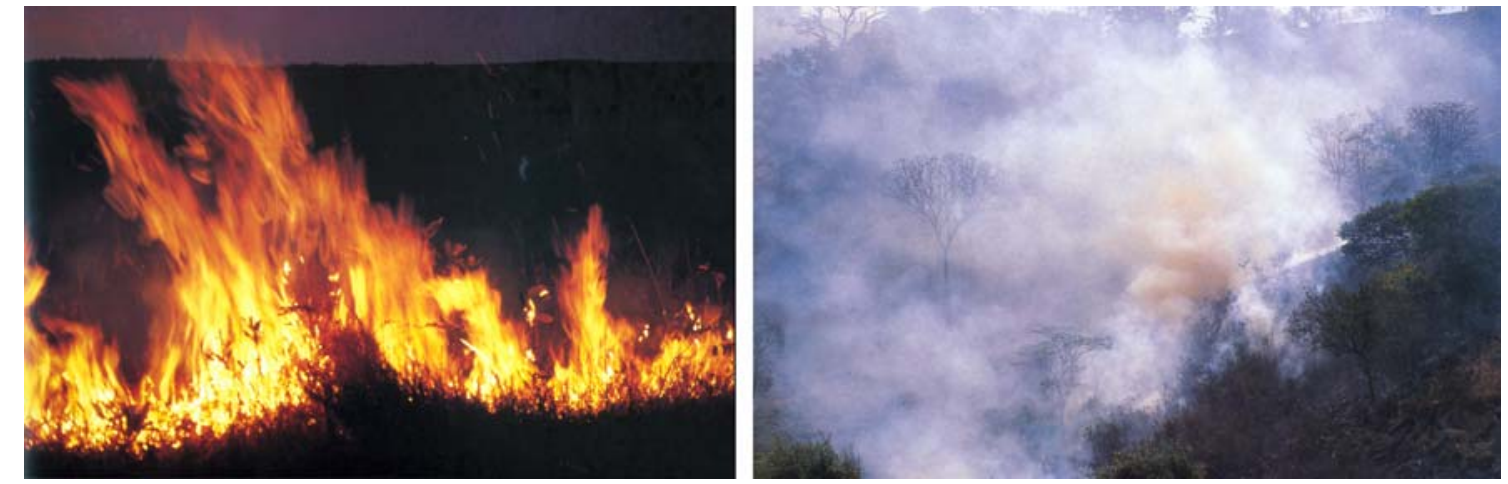

Figura 17 - "Fogo no Cerrado" - Exemplo de fotos chocantes para possível campanha de prevenção de incêndio

Fonte: FAQUINI, 1999.

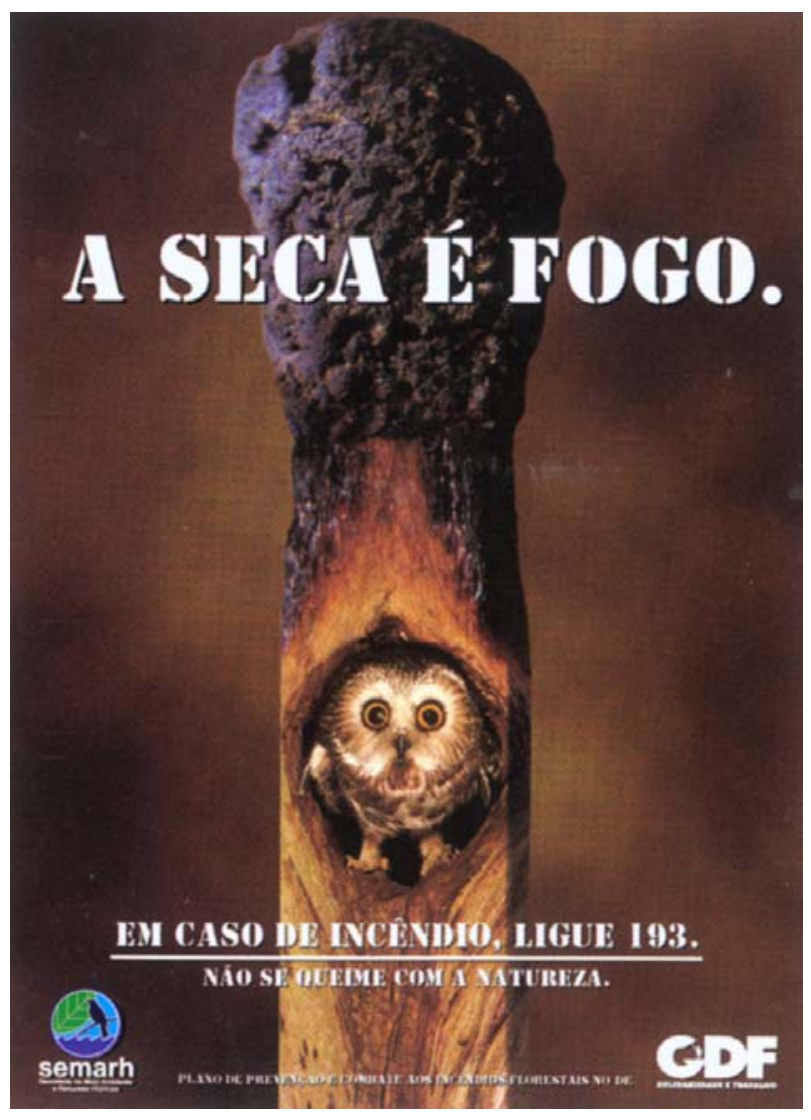

Figura 18 - "Anúncio GDF" - Exemplo de campanha de prevenção e denuncio de incêndios

Fonte: Revista Portfolio Magazine, n. 1, fev. 2003, Brasília, Charbel Gráfica e Editora Ltda. 
Expondo a foto de um grande incêndio, ou de um campo ou floresta recémincendiados, o público com certeza vai se sensibilizar com o impacto transmitido pela imagem, e ao mesmo tempo perceberá os danos que um incêndio pode provocar à flora, e principalmente à fauna, esta última normalmente esquecida pelos leigos no assunto.

Dessa forma, a educação ambiental se torna completa, mostrando, de forma dramática, os drásticos efeitos de um acidente ambiental como aquele noticiado.

Todavia, pelo fato de ter esse destaque, não há espaço para maiores explicações. Características como frases longas, endereço, instruções ou outro tipo de explicações não fazem parte de uma mensagem eficiente, sob pena de o fator impacto ficar comprometido.

A objetividade, portanto, é imprescindível para a eficiência da mensagem do conceito abordado.

\section{3 - VISIBILIDADE}

A mídia exterior é um dos meios que mais exibe o produto, serviço ou conceito veiculado. Pelo fato de as dimensões dos painéis serem geralmente bastante ampliadas, ou quando não o são, têm localização privilegiada no meio externo, cuja visibilidade desse meio garante excepcional destaque à mensagem veiculada, permitindo, por exemplo, que a exibição de imagem de um Parque Nacional se integre à paisagem onde está localizado o engenho publicitário. 


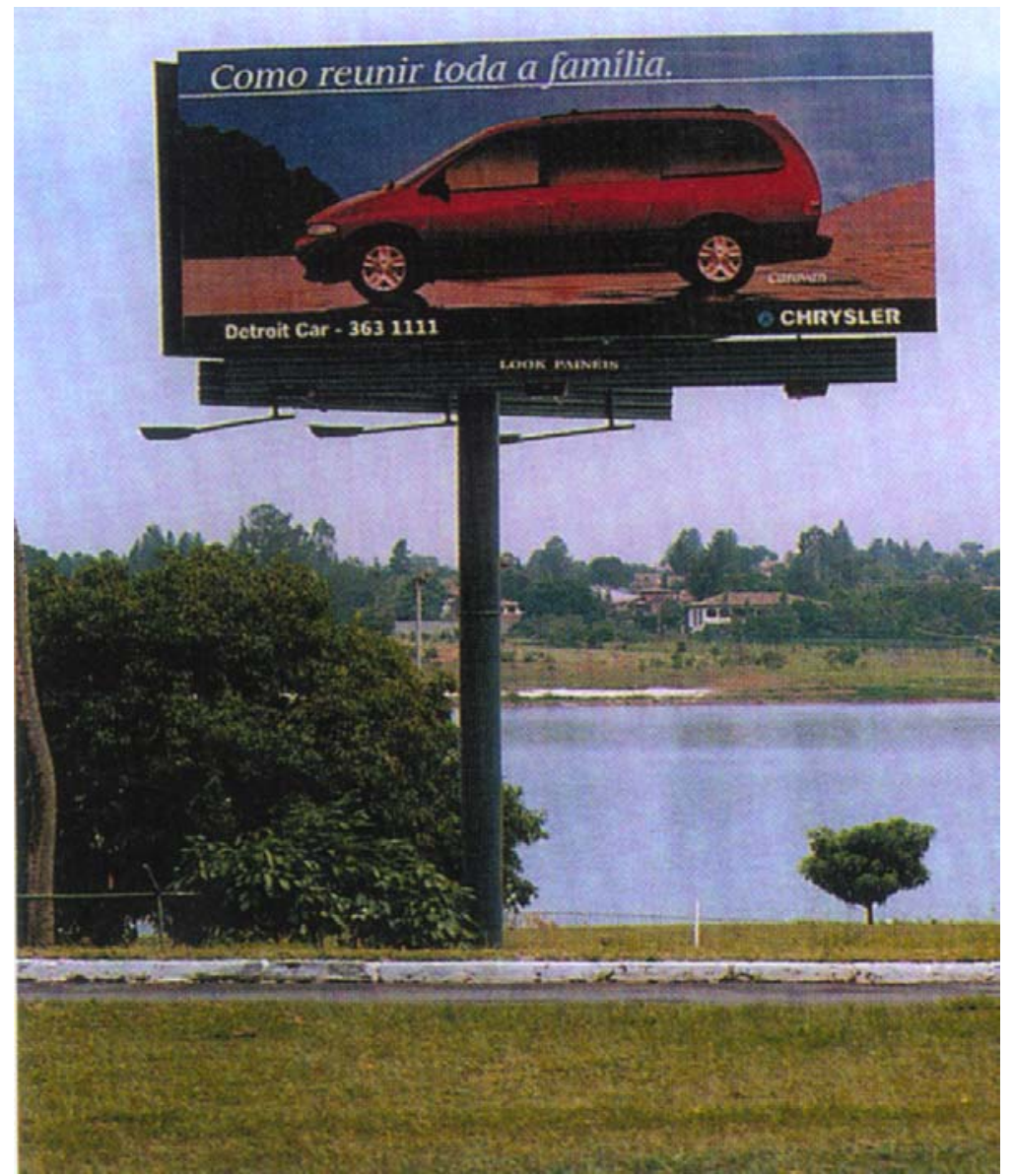

\section{Figura 19 - "Front-Light em área verde" - Possibilidade de campanha de Parques Nacionais, com integração com paisagem natural - landscape}

Fonte: Revista Sinal Extensivo, ano 4, n. 34, set. 2002, p. 42, Mozarzel Edições e Promoções Ltda.

Dessa forma, a imagem do Parque será valorizada pelo formato, pelas dimensões e pela localização do painel.

Outro exemplo é o de embarcações que atravessam diariamente determinado canal ou baía. Nela, pode-se expor uma mensagem de reafirmação de limpeza e equilíbrio ecológico de rios, lagos e oceanos, lembrando as pessoas das atitudes de cada um com relação a essa realidade. 


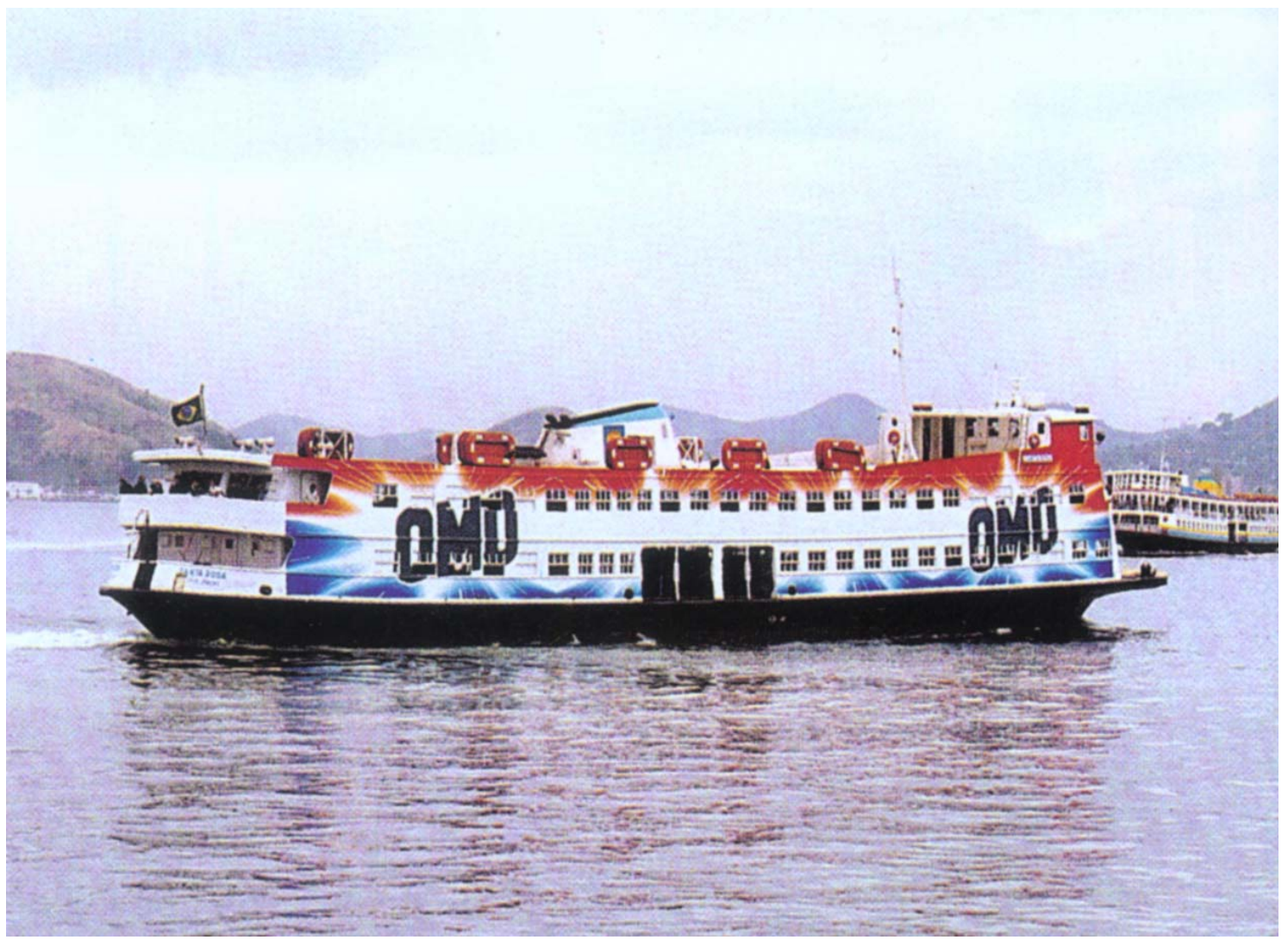

Figura 20 - "Barca em canal" - Possibilidade de campanha de águas despoluídas

Fonte: Revista Sinal Extensivo, ano 4, n. 34, set. 2002, p. 32, Mozarzel Edições e Promoções Ltda.

\section{4 - FREQÜÊNCIA ININTERRUPTA}

Pode-se afirmar que a mídia exterior é a mídia que "não se desliga". O cidadão pode desligar o rádio, a TV, pode fechar o jornal, a revista, mas a mídia exterior está nas ruas, exposta 24 horas por dia e dependendo da negociação da empresa exibidora com a empresa que aluga esse espaço, podendo ficar exposta ininterruptamente durante anos.

A exposição é continuada dia-a-dia. É praticamente impossível se fazer um percurso diário ou esporádico passando por uma mesma via pública sem perceber a mensagem integrada à paisagem onde está inserida, pois ela está lá, nos mesmos locais, todos os dias. Isso faz com que se torne uma mídia compulsória, o que também traz uma enorme responsabilidade social. 
Quando se quiser expor um conceito, propor uma mudança de hábito, lembrar de uma atitude a ser tomada diante de determinada situação como, por exemplo, somente jogar lixo em locais apropriados, não alimentar os animais silvestres, permanecer a certa distância de locais perigosos, enfim, quando se necessitar que uma mensagem se repita até ser assimilada por um número específico de pessoas, a mídia exterior oferece essa freqüência, a qual é uma das características mais expressivas desse meio.

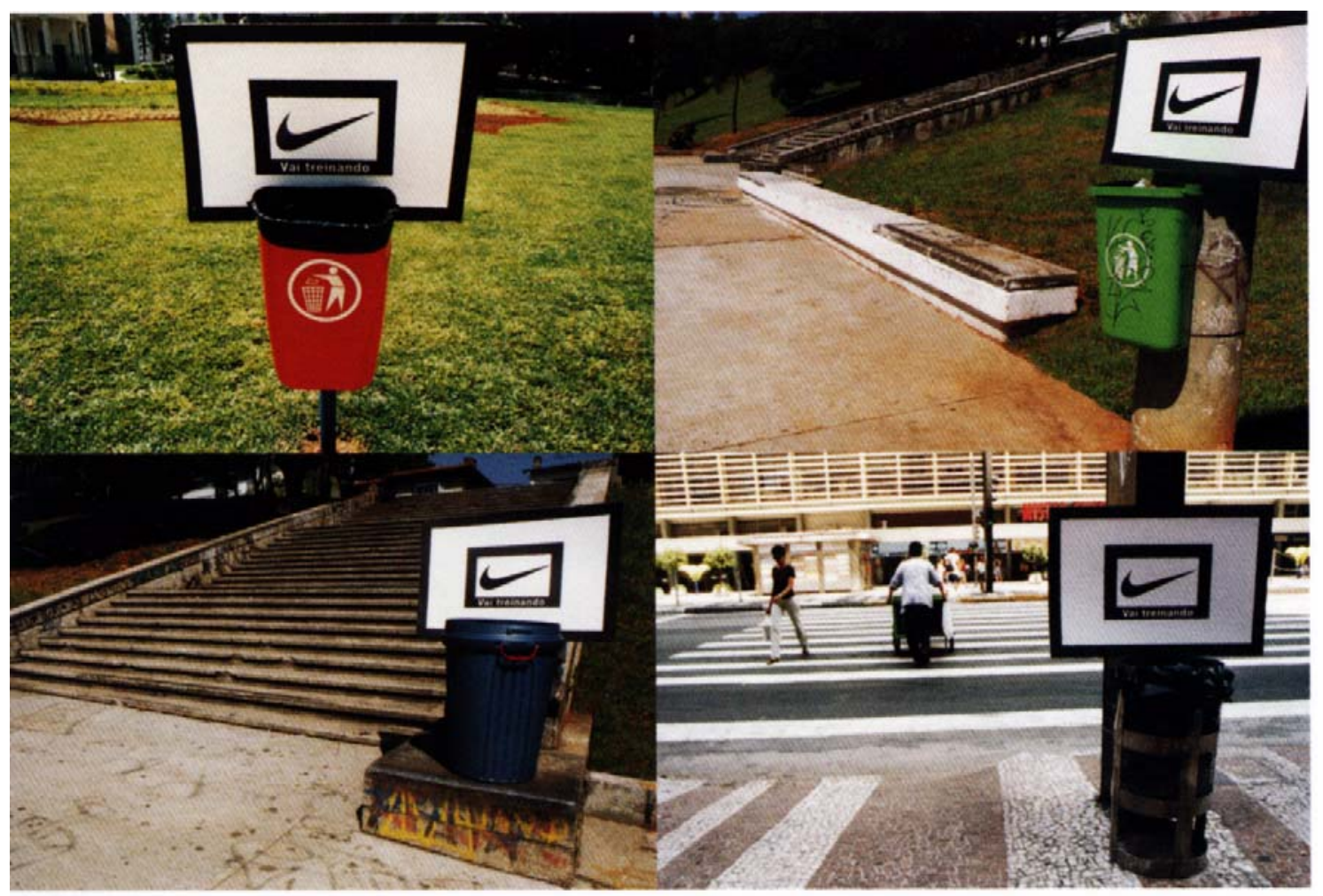

Figura 21 - "Campanha Nike" - Exemplo de campanha de educação ambiental Fonte: $27^{\circ}$ Anuário do Clube de Criação de São Paulo, 2002, p. 245. 


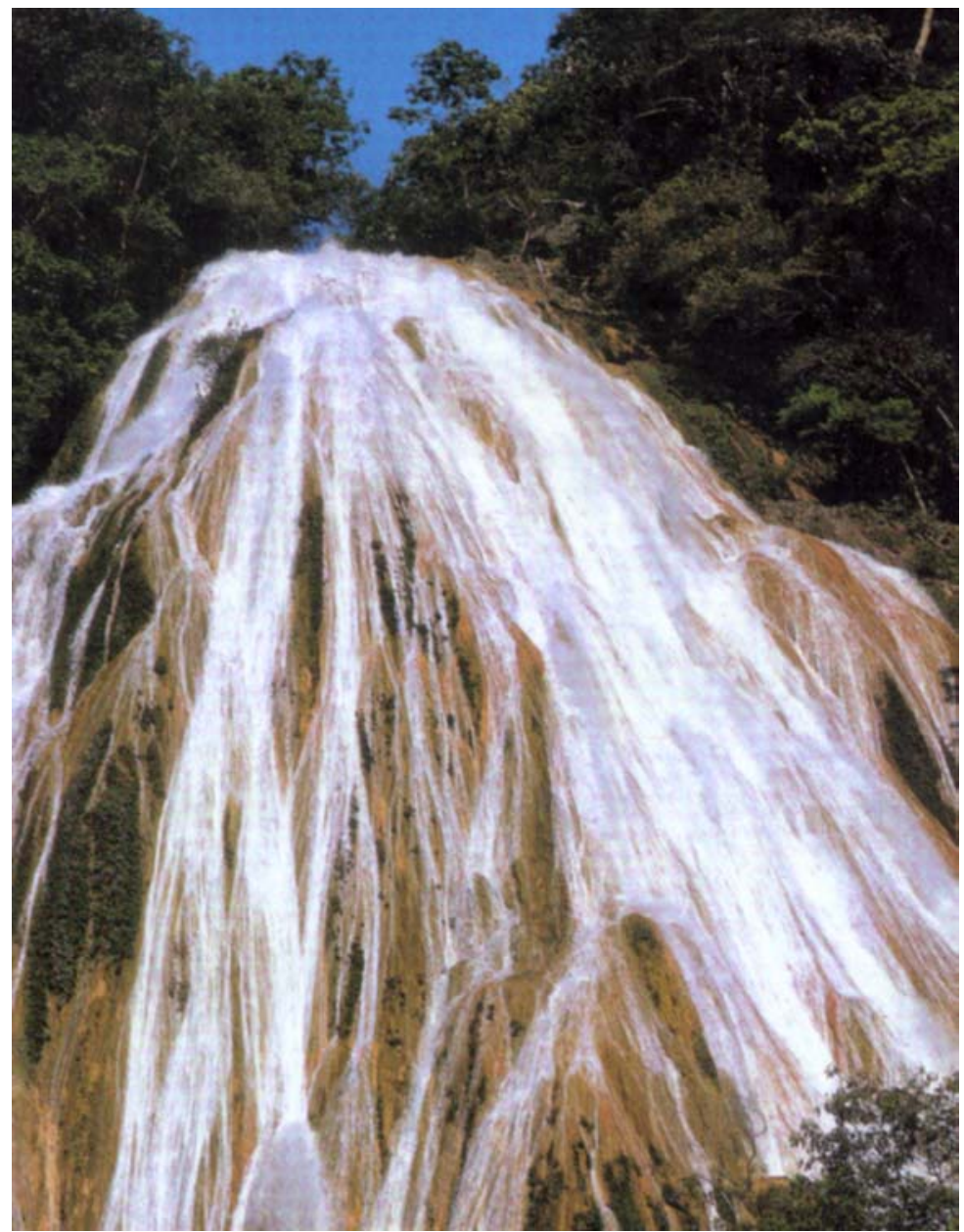

\section{Figura 22 - "Cachoeira de Bonito - MS" - Possibilidade de campanha de} interpretação ambiental com prevenção de perigos na natureza

Fonte: Guia Ecológico Brasil. Região de Bonito, MS. Guia no 1, 4. ed., p. 47.

\section{5 - ACESSIBILIDADE}

Pelo fato de estar em espaços abertos, nas vias públicas, a mídia exterior é ao mesmo tempo uma mídia totalmente acessível, não necessitando ser comprada, nem ligada, nem folheada, nem se cobra ingresso para vê-la.

Por isso mesmo, é um meio de comunicação que garante o resultado de ser visto por toda uma cidade, independente de classe social, faixa etária, sexo, credo ou local de residência.

Dessa forma, em uma situação de massificação de uma informação, esse é o meio mais indicado para se atingir todas as classes de um determinado centro urbano. Se for do interesse do governo local, estadual ou federal incentivar e dirigir os passeios 
turísticos da população de determinadas cidades para a prática do ecoturismo, a mídia exterior pode ser usada com garantia de alcance a toda a população.

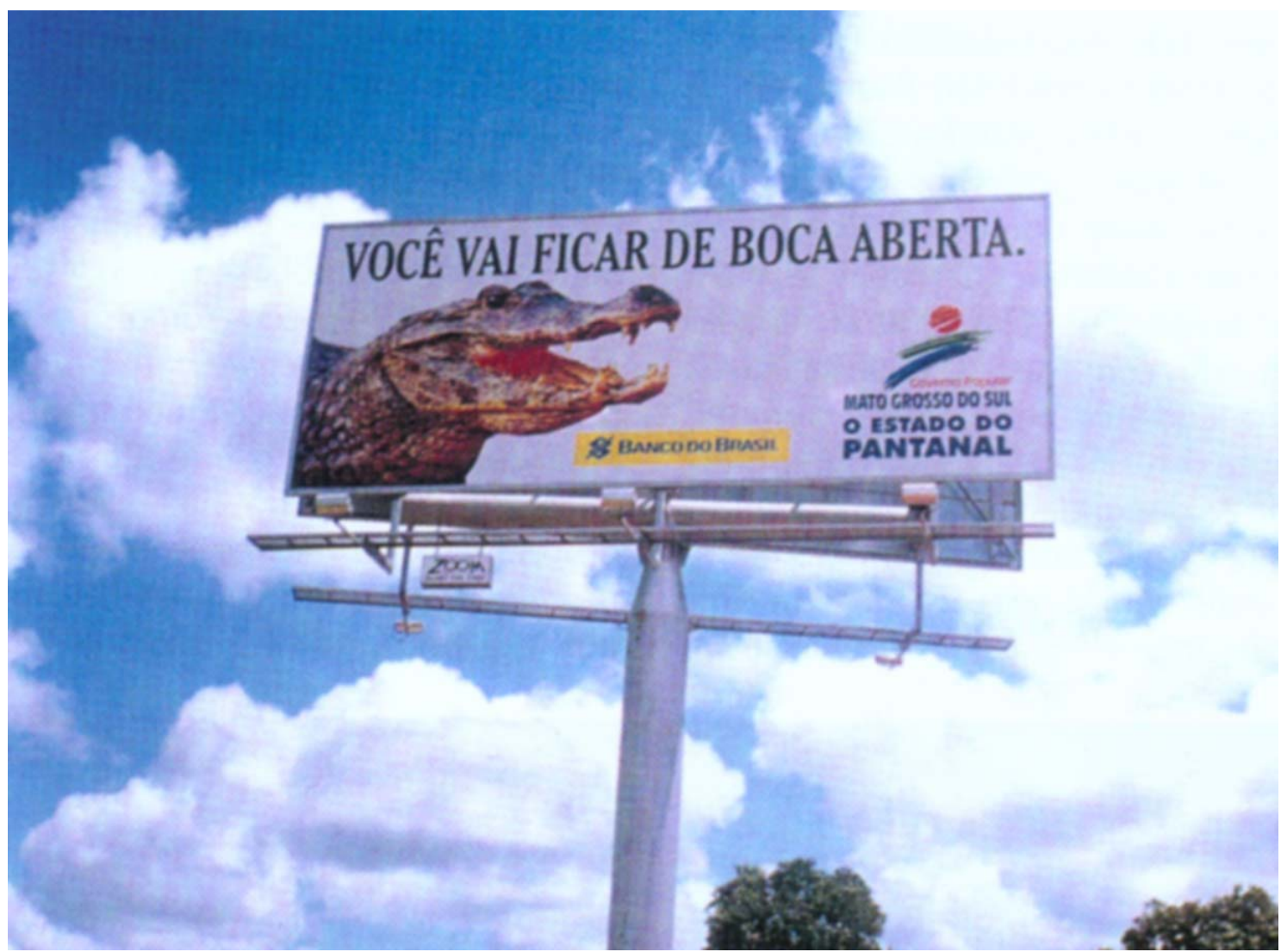

\section{Figura 23 - "Campanha do Pantanal" - Exemplo de campanha dirigida ao ecoturismo}

Fonte: Revista Sinal Extensivo, ano 4, n. 34, set. 2002, p. 40, Mozarzel Edições e Promoções Ltda.

E, para isso, estimular atitudes ecologicamente saudáveis, por meio da educação ambiental, citando exemplos de comportamentos a serem adotados em situações comuns desse tipo de turismo como, por exemplo, tirar apenas fotos, levar consigo todo o lixo ou sobras da viagem, etc. Outro exemplo de empresas que podem investir nessa atividade são as indústrias de filmes fotográficos, promovendo parcerias com reveladoras locais e com os próprios empreendimentos ecoturísticos. 


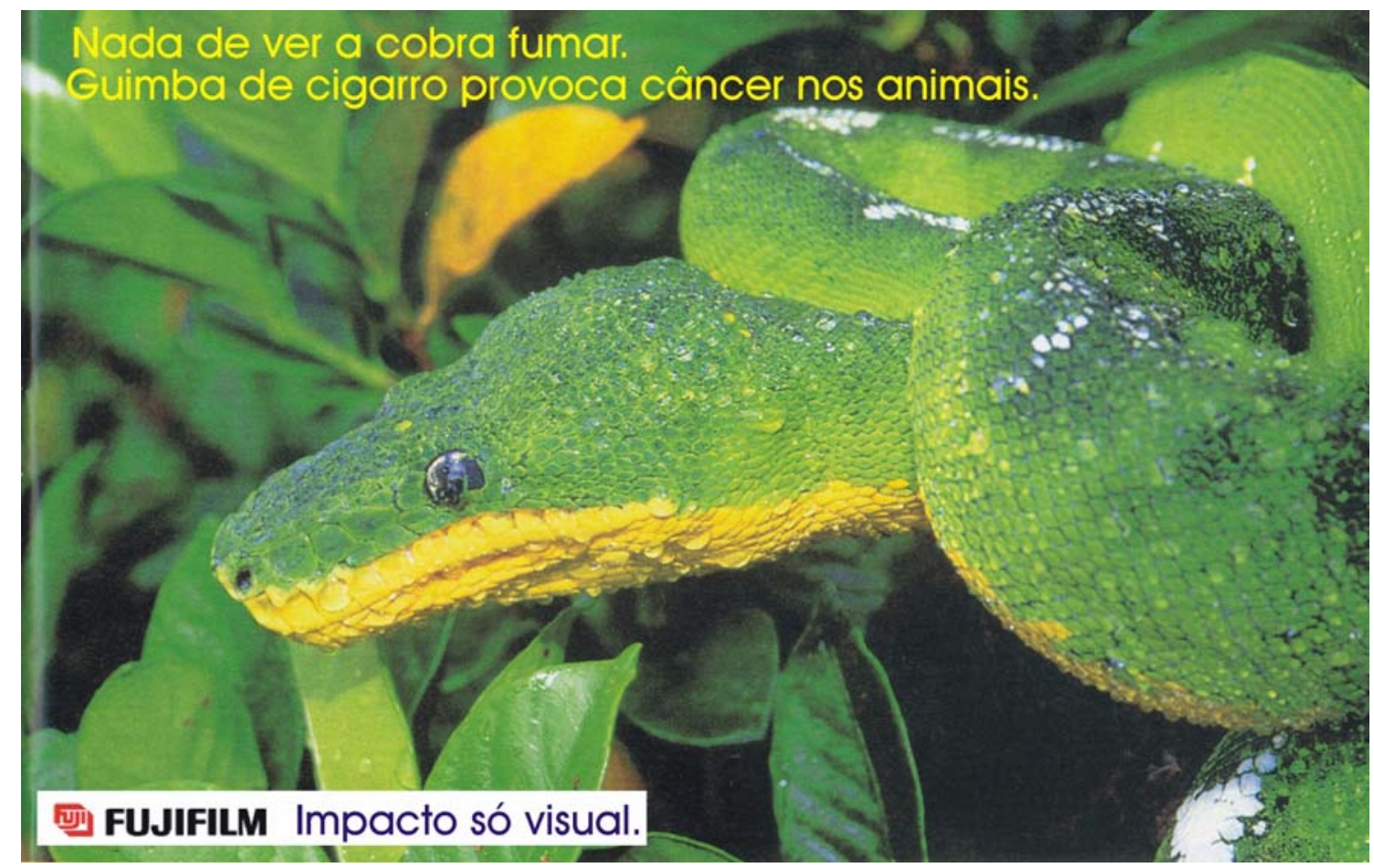

Figura 24 - "Campanha Yashica" - Exemplo de campanha de empresa privada ao estímulo da prática ao ecoturismo

Fonte: Criação própria da autora.

\section{6 - INSTANTANEIDADE}

A mídia exterior consegue comunicar uma mensagem de maneira praticamente instantânea. Por meio de um bom planejamento de locais, pode-se cobrir toda uma cidade da noite para o dia, ampliando-se ainda mais o impacto da comunicação.

Aliando-se às características de formato, normalmente grandes painéis ou engenhos fixos ou móveis, instalados em pontos estratégicos da cidade como, por exemplo, uma fachada de edifício, também chamada de empena luminosa, transmite-se, em dois ou três segundos, uma nova sugestão de atividade ecoturística como, por exemplo, uma imagem de cachoeira sendo escalada por praticantes de rappel, com o objetivo de divulgar determinada marca da indústria de equipamentos e acessórios esportivos. 

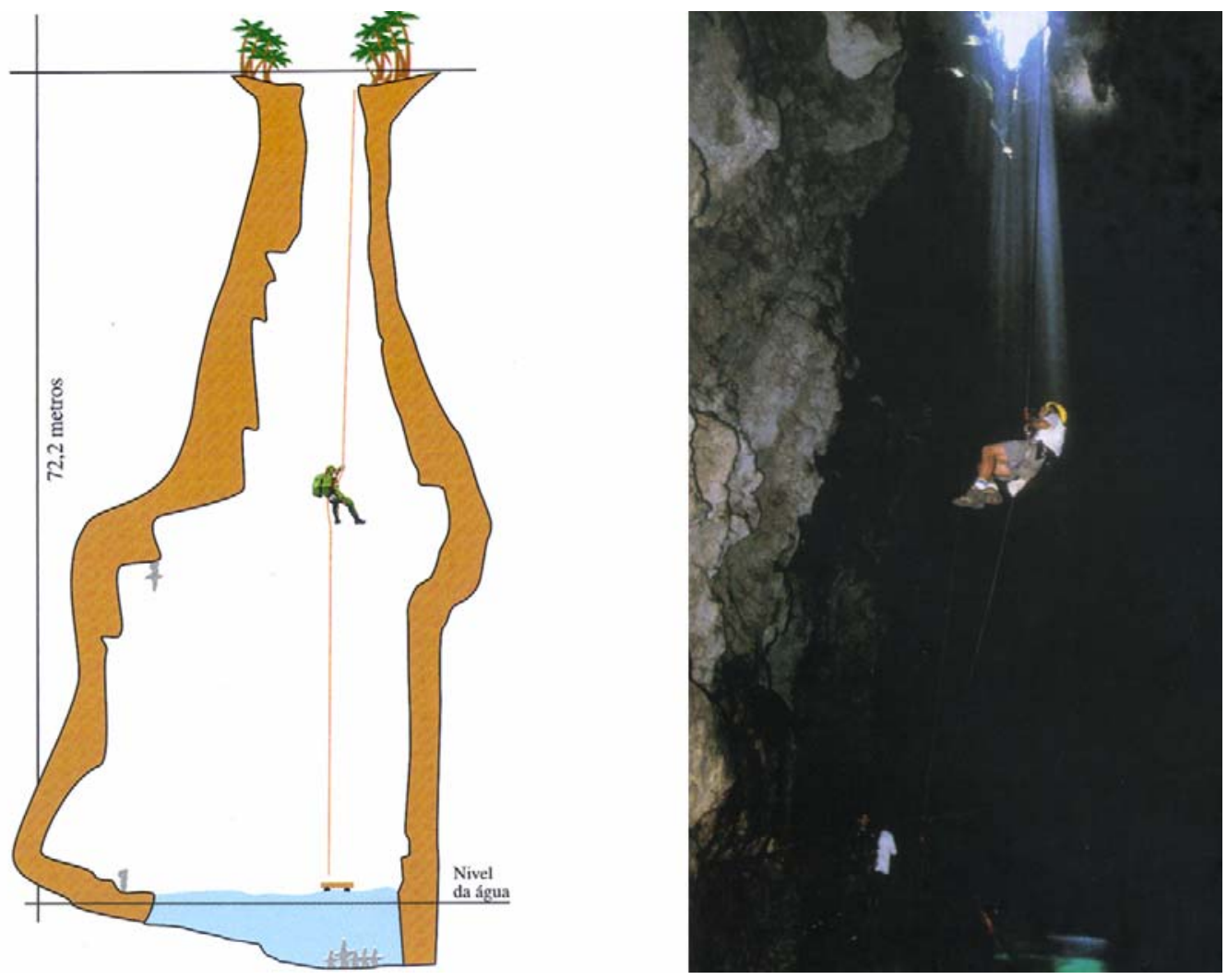

Figura 25 - "Rappel em Bonito - MS" - Exemplo de estímulo rápido. Imagem já desperta a curiosidade

Fonte: Guia Ecológico Brasil. Região de Bonito, MS. Guia nº 1, 4. ed.

\section{7 - Cobertura Abrangente e Segmentada}

A mídia exterior pode atingir toda a população que circula nas ruas de uma cidade, porém, a viabilidade de segmentação dessa mídia também é comprovada pelas pesquisas divulgadas na revista Meio \& Mensagem.

$\mathrm{Na}$ medida em que o anunciante tem total liberdade de escolha do local geográfico, onde são oferecidos os engenhos publicitários, a mensagem veiculada atingirá tão-somente um determinado público de uma cidade. Por exemplo, uma campanha programada para ser instalada apenas na Asa Sul de Brasília atingirá um público totalmente diferente de uma outra campanha veiculada na periferia de Goiânia. 


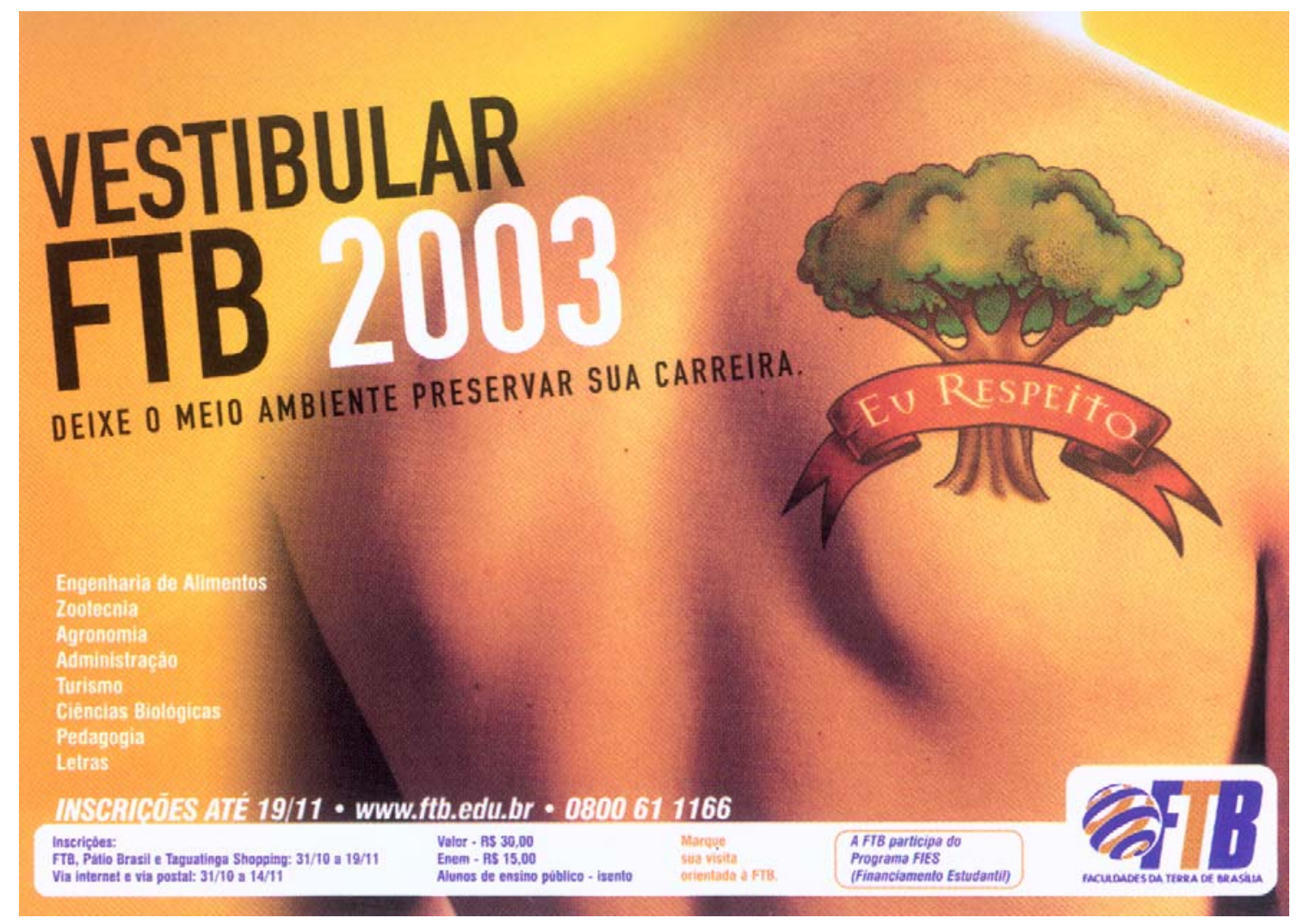

Figura 26 - "Anúncio Faculdade Terra de Brasília" - Público dirigido

Fonte: Revista Portfolio Magazine, n. 1, fev. 2003, Brasília, Charbel Gráfica e Editora Ltda.

Por meio da segmentação, será possível incluir a instalação das mensagens em roteiros específicos, previamente estudados, sem desperdício de verba financeira. Um exemplo é um roteiro que cubra as imediações de faculdades, universidades, boates e shopping centers, com o objetivo de atingir um público de jovens economicamente ativos, que possa interessar a uma indústria de calçados para caminhadas e escaladas. 


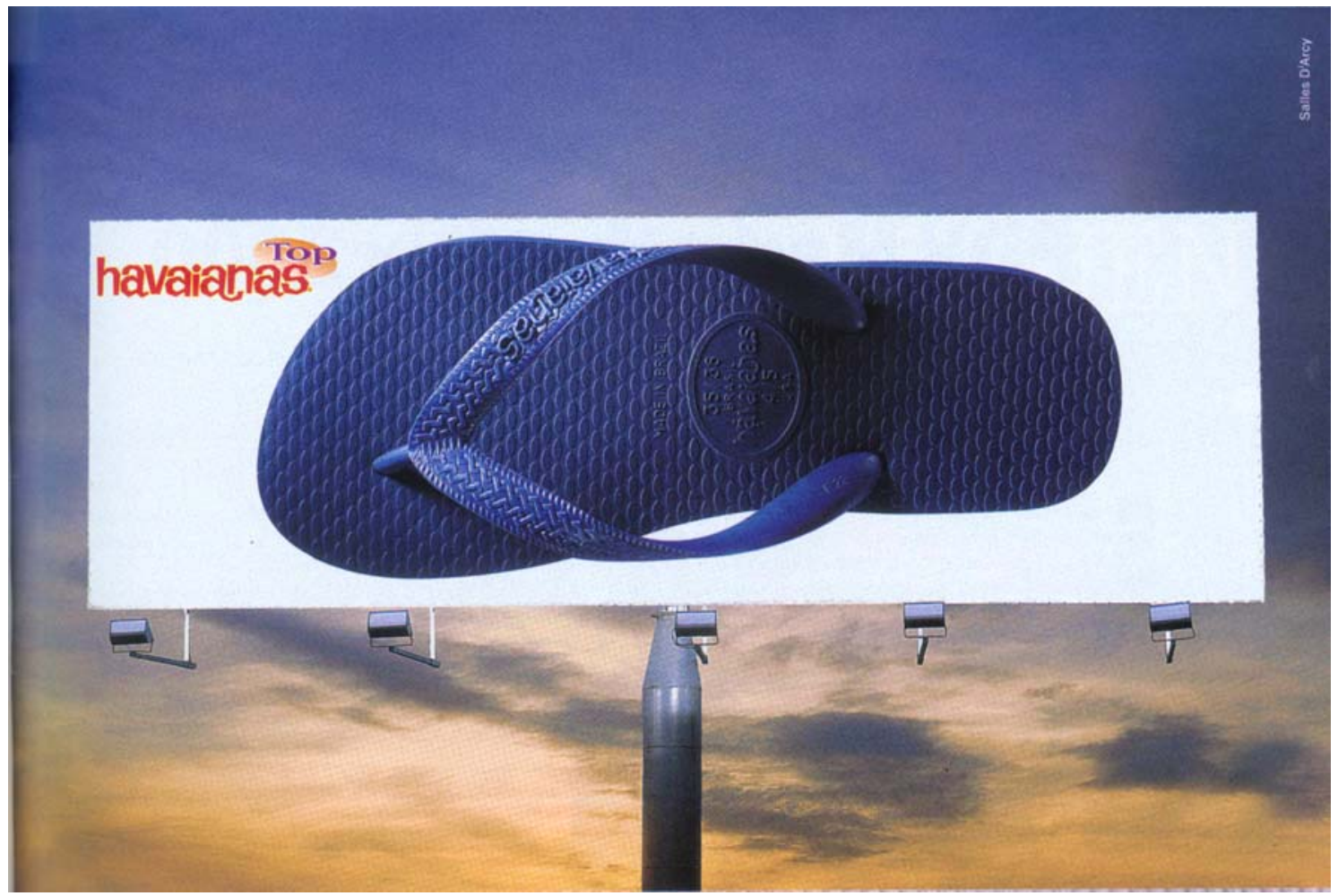

Figura 27 - "Havaianas" - Exemplo de anúncio de calçados para a prática de esportes na natureza. Possibilidade de integração como landscape

Fonte: Revista Sinal Extensivo, ano 7, n. 59, jan. 2003, Mozarzel Edições e Promoções Ltda.

\section{8 - Artefatos de Mídia EXterior}

Diante do avanço tecnológico e de constantes pesquisas em materiais mais duráveis, com maior apelo visual, com maior integração ao meio externo e inovações de cores e formatos, a todo o momento surgem novos artefatos de mídia exterior, que se chamará, no presente trabalho, de engenhos publicitários.

Os engenhos publicitários mais conhecidos atualmente e mais comuns de serem vistos são os seguintes: 
- Outdoor, o mais antigo meio de comunicação exterior.

Segundo a Central de Outdoor, o ano oficial de origem deste engenho foi 1793, com a invenção da litografia, pelo austríaco Alois Senefelder.

Data de agosto de 1929, em São Paulo, a instalação da primeira empresa exibidora de outdoor do País: a Publix, em atividade até os dias de hoje.

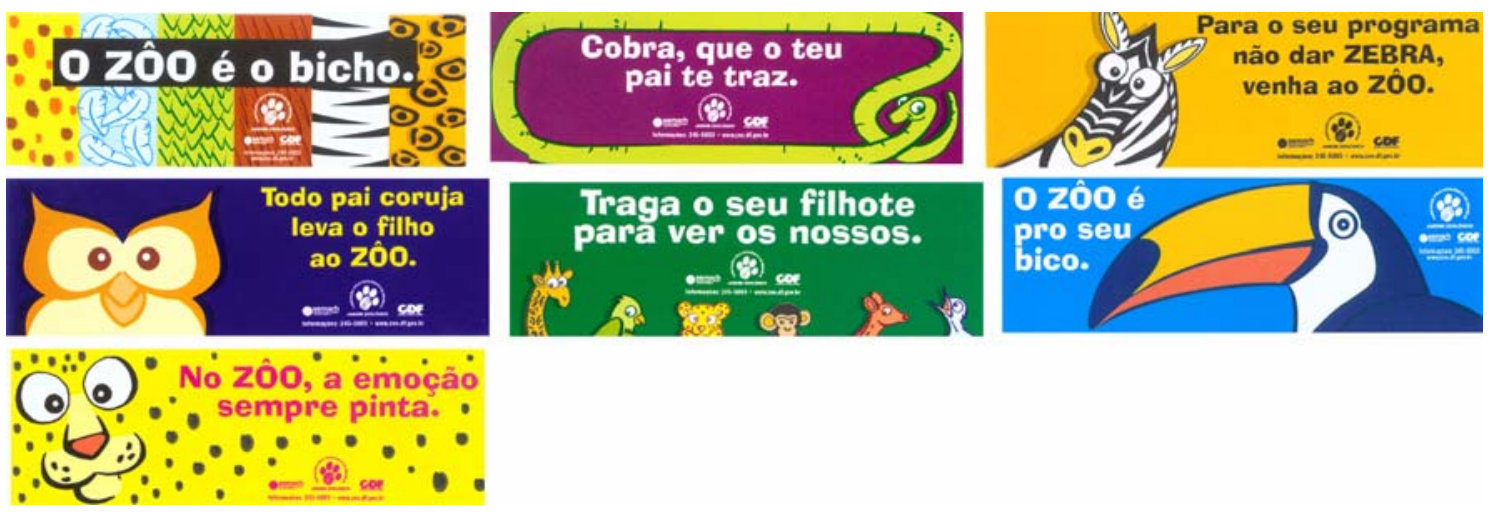

Figura 28 - "Outdoor em Brasília" - Campanha de estímulo à visitação ao Zôo de Brasília

Fonte: Arquivo de fotos Comprovação da Nova Mídia Visuplac.

- Back-Light

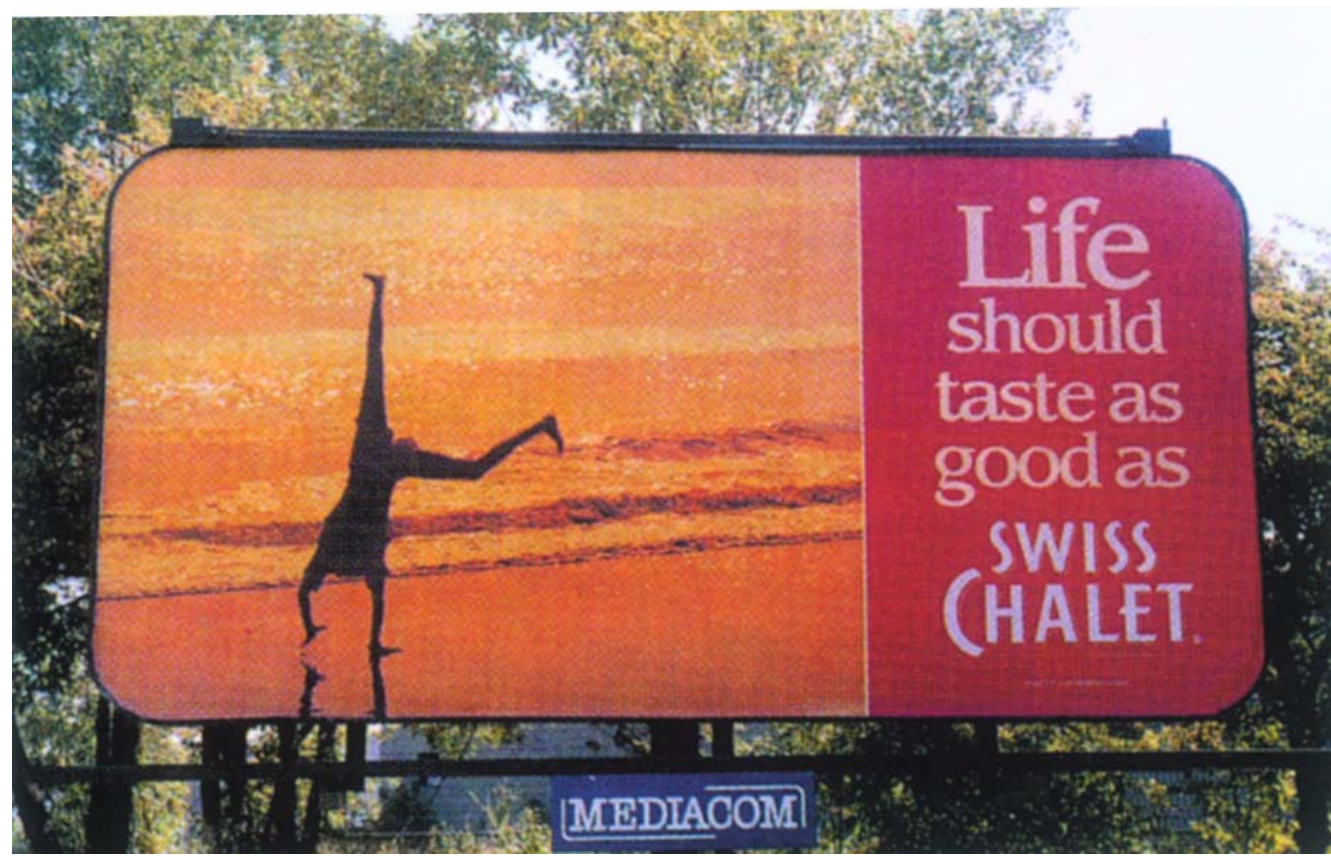

Figura 29 - "Back-Light no Canadá"

Fonte: Revista Sinal Extensivo, ano 4, n. 34, set. 2002, p. 22, Mozarzel Edições e Promoções Ltda. 
- Front-Light
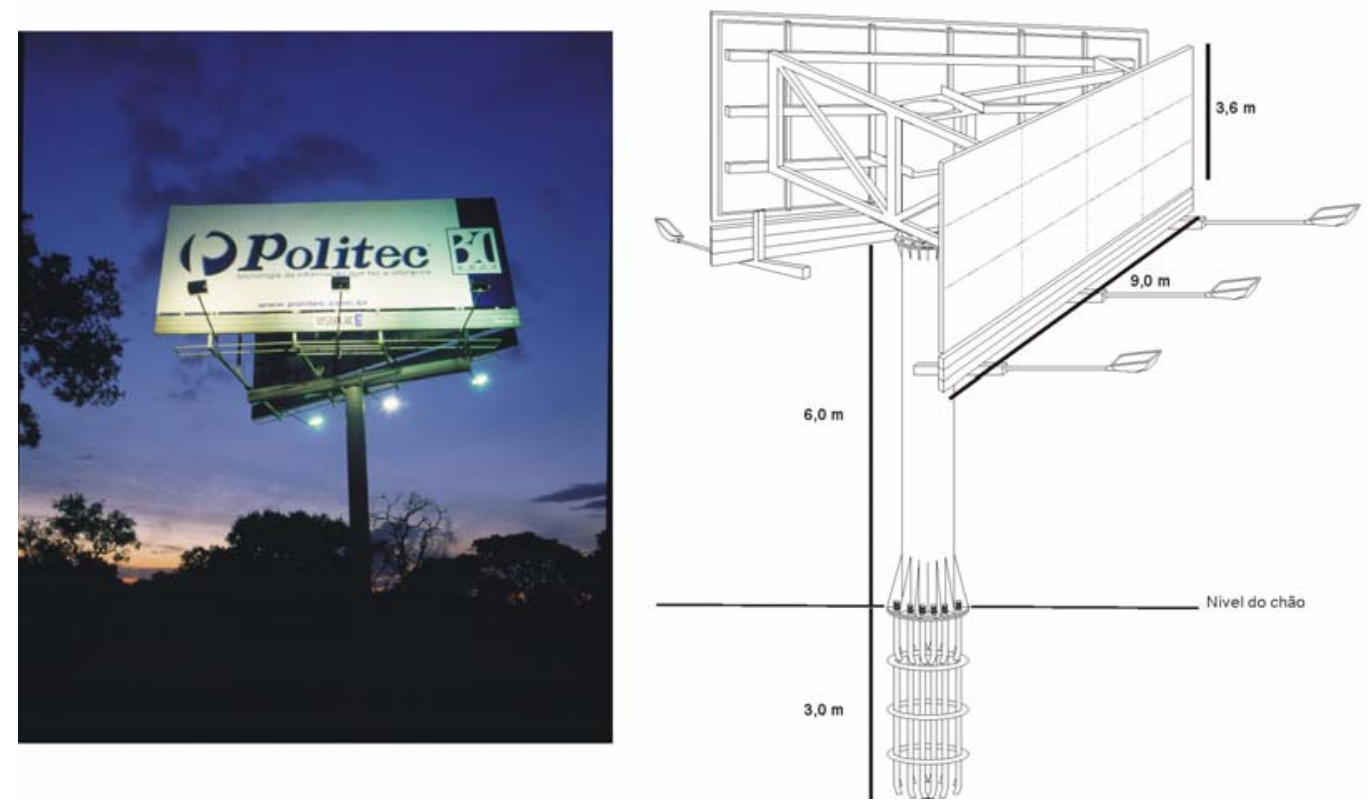

Figura 30 - "Front-Light Visuplac"

Fonte: Manual de Informações Técnicas da Nova Mídia Visuplac.

- Totem

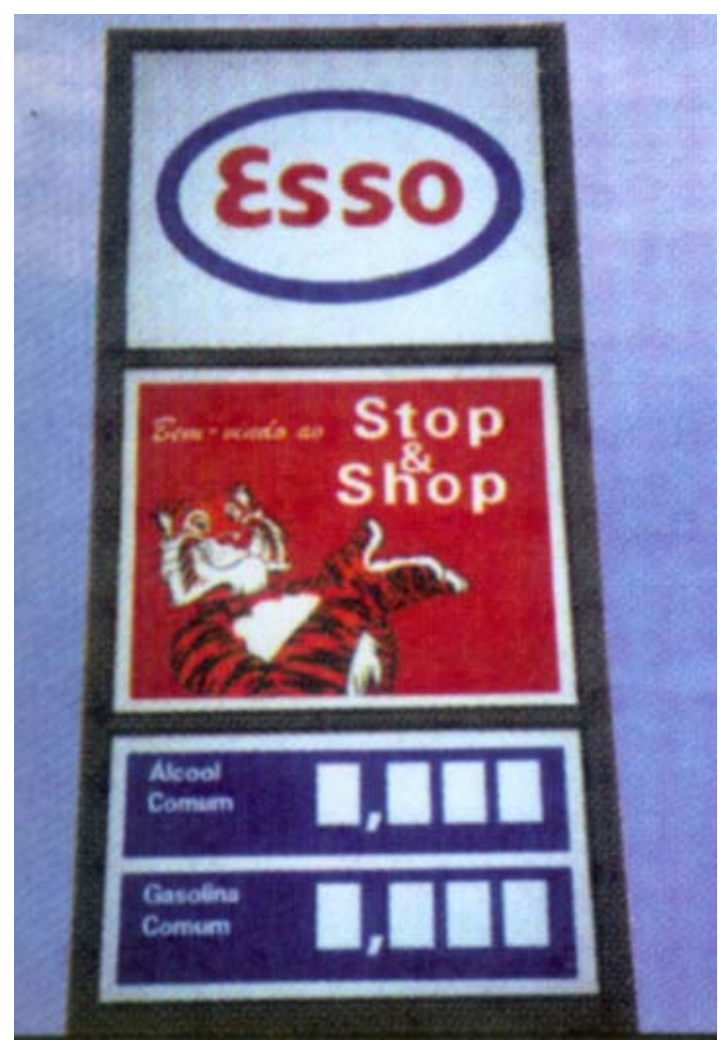

Figura 31 - "Totem Esso"

Fonte: Jornal Meio \& Mensagem. Mídia Exterior. Edição Especial, 14 out. 2002. 
- Relógio / Termômetro
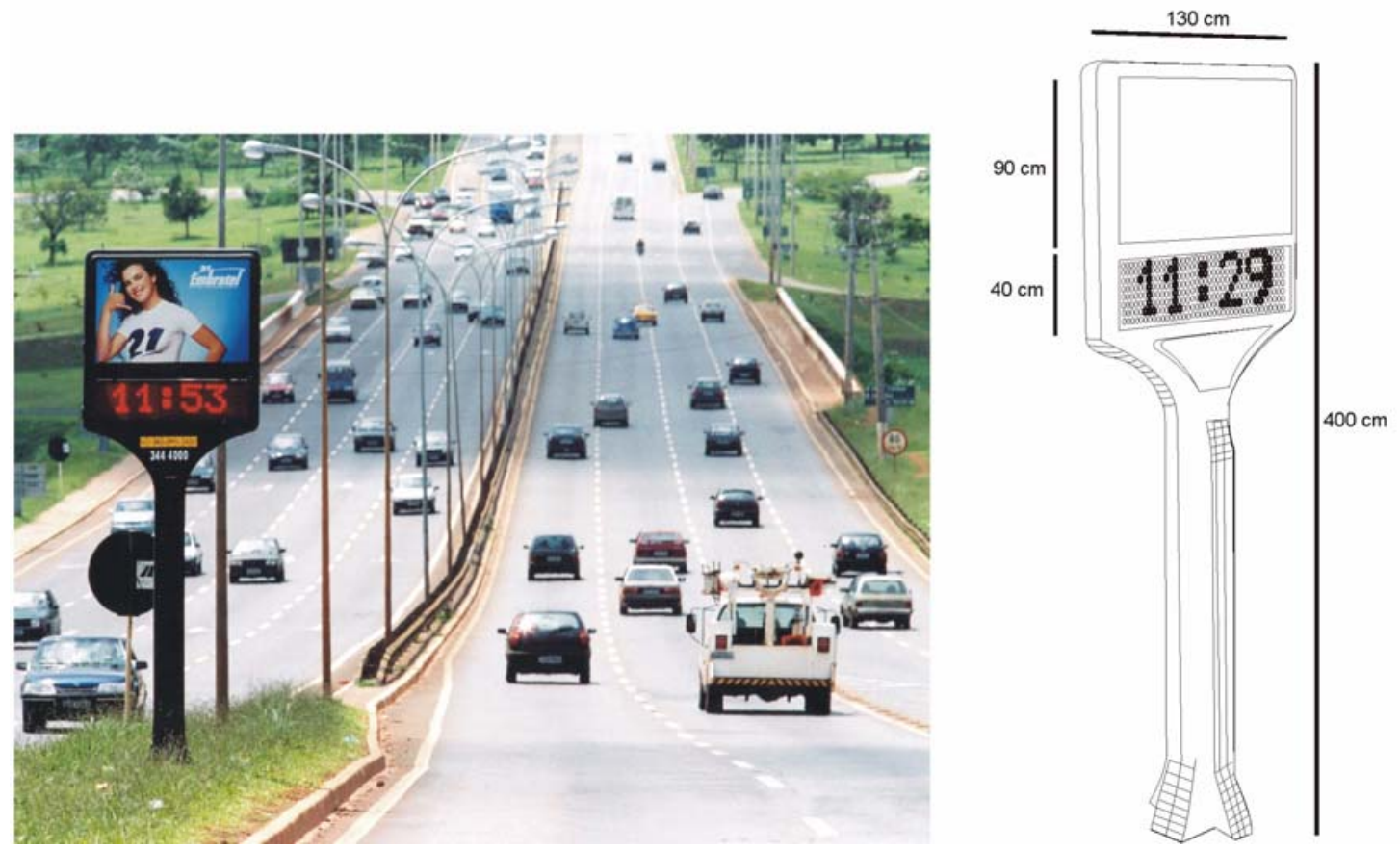

Figura 32 - "Relógio / Termômetro"

Fonte: Manual de Informações Técnicas da Nova Mídia Visuplac.

- Fachada de Edifício ou Empena Luminosa
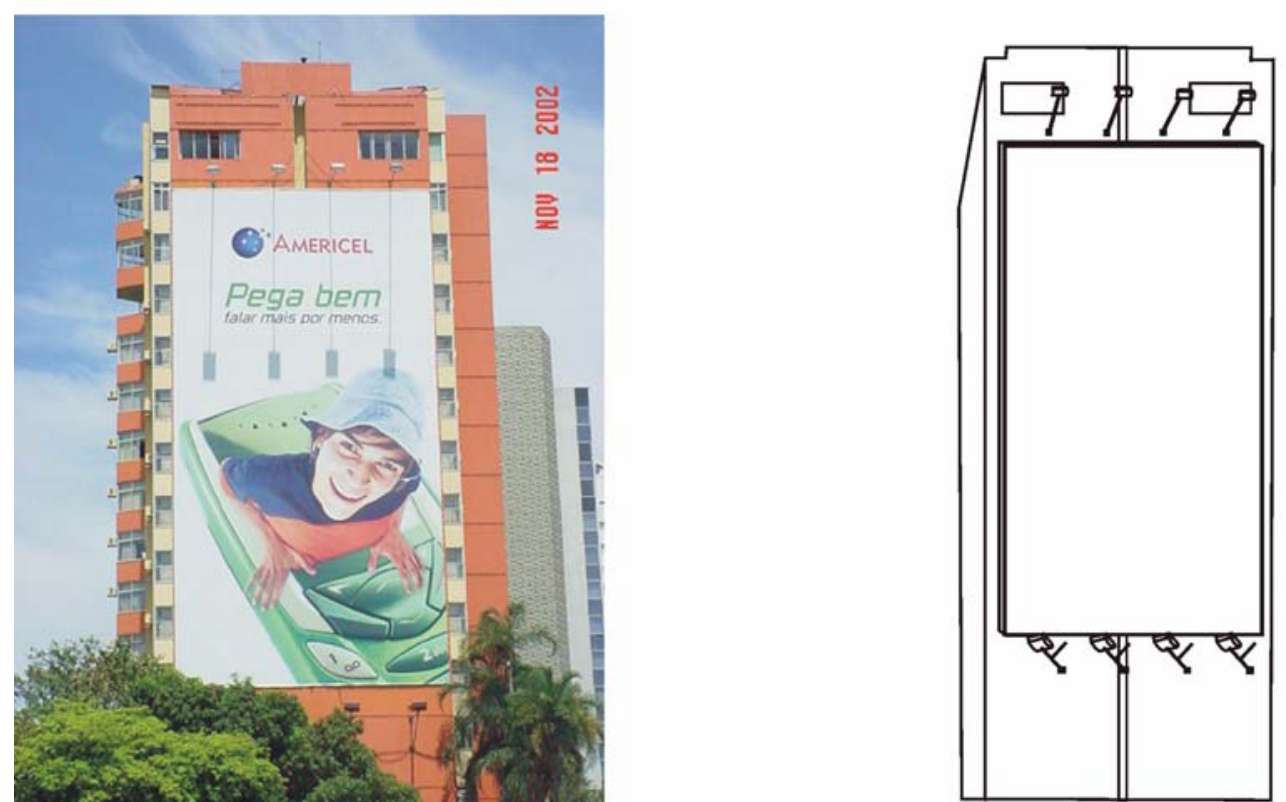

Figura 33 - "Empena"

Fonte: Manual de Informações Técnicas da Nova Mídia Visuplac. 
- Ônibus

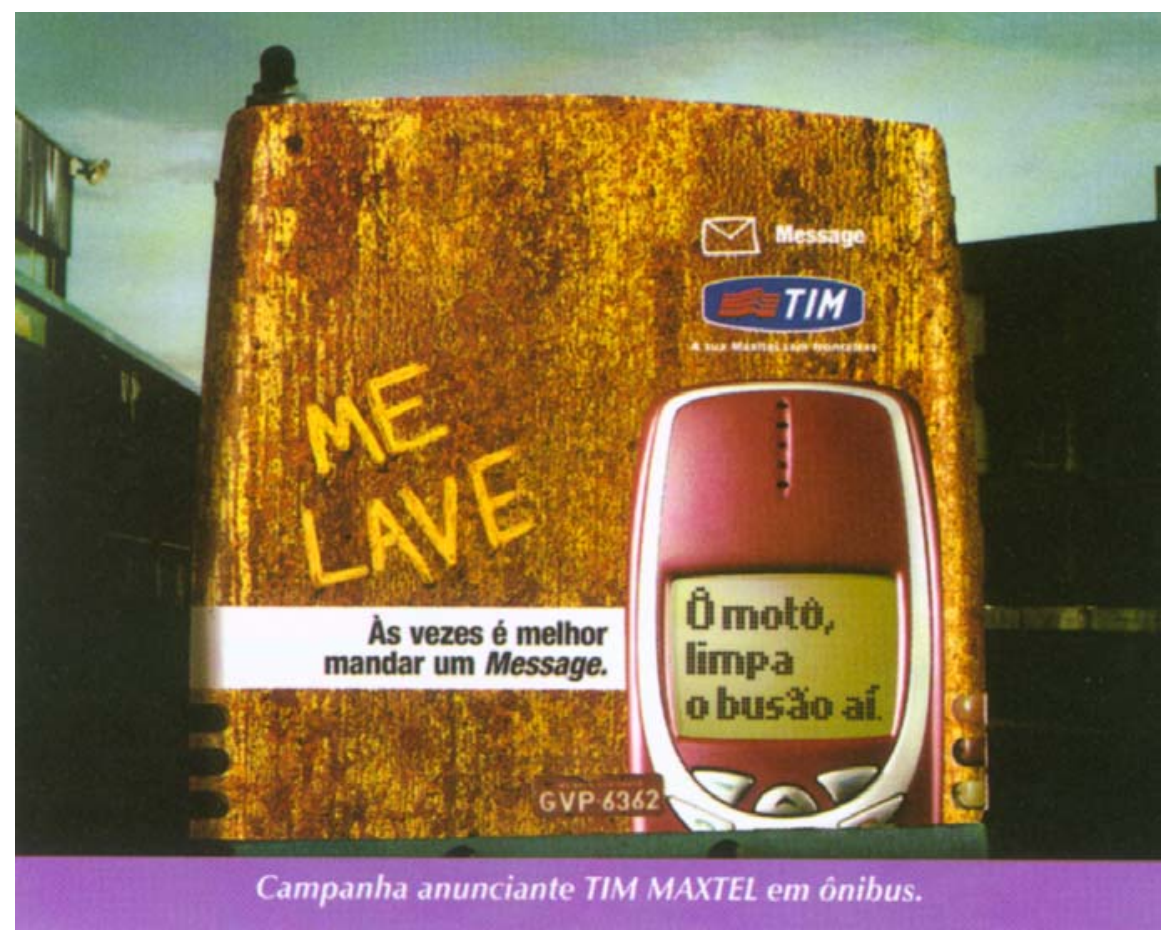

Figura 34 - "Ônibus"

Fonte: Revista Sinal Extensivo, ano 7, n. 59, jan. 2003, Mozarzel Edições e Promoções Ltda.

- Táxis

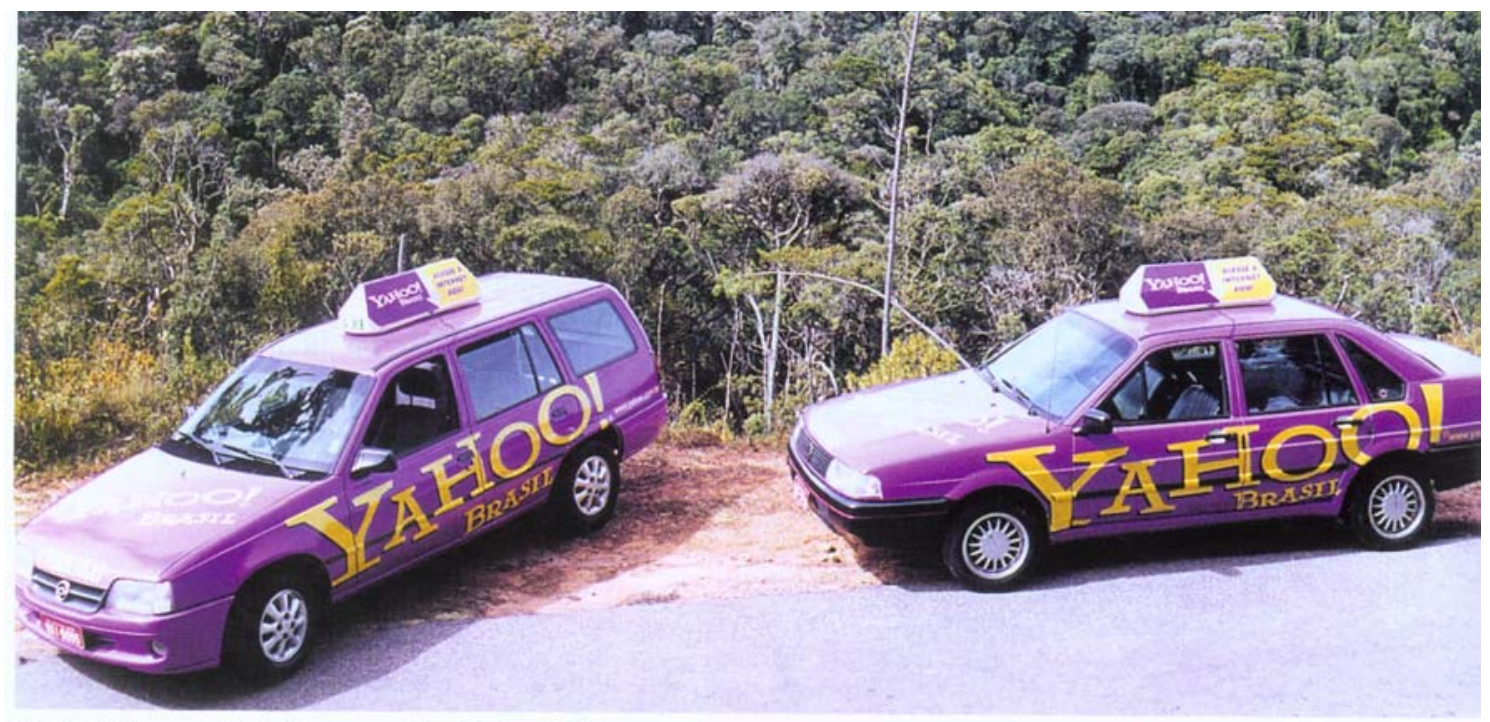

O visual inconfundivel chamou a atenção do público

\section{Figura 35 - "Táxis"}

Fonte: Revista Sinal Extensivo, ano 4, n. 34, set. 2000, Mozarzel Edições e Promoções Ltda. 
- Metrô

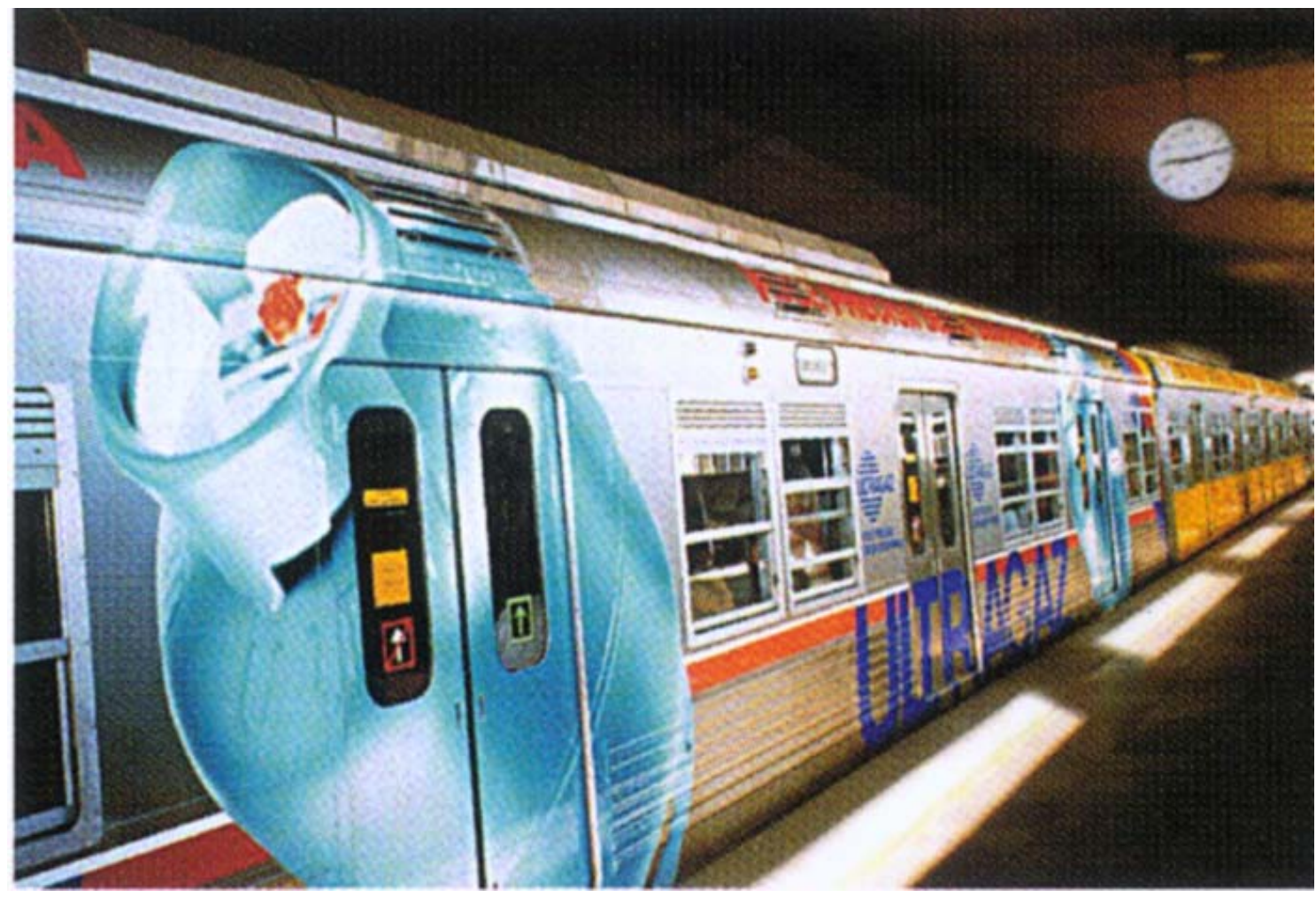

Figura 36 - "Metrô"

Fonte: Jornal Meio \& Mensagem. Edição Especial. Mídia Exterior, 19 mar. 2001.

- Trens

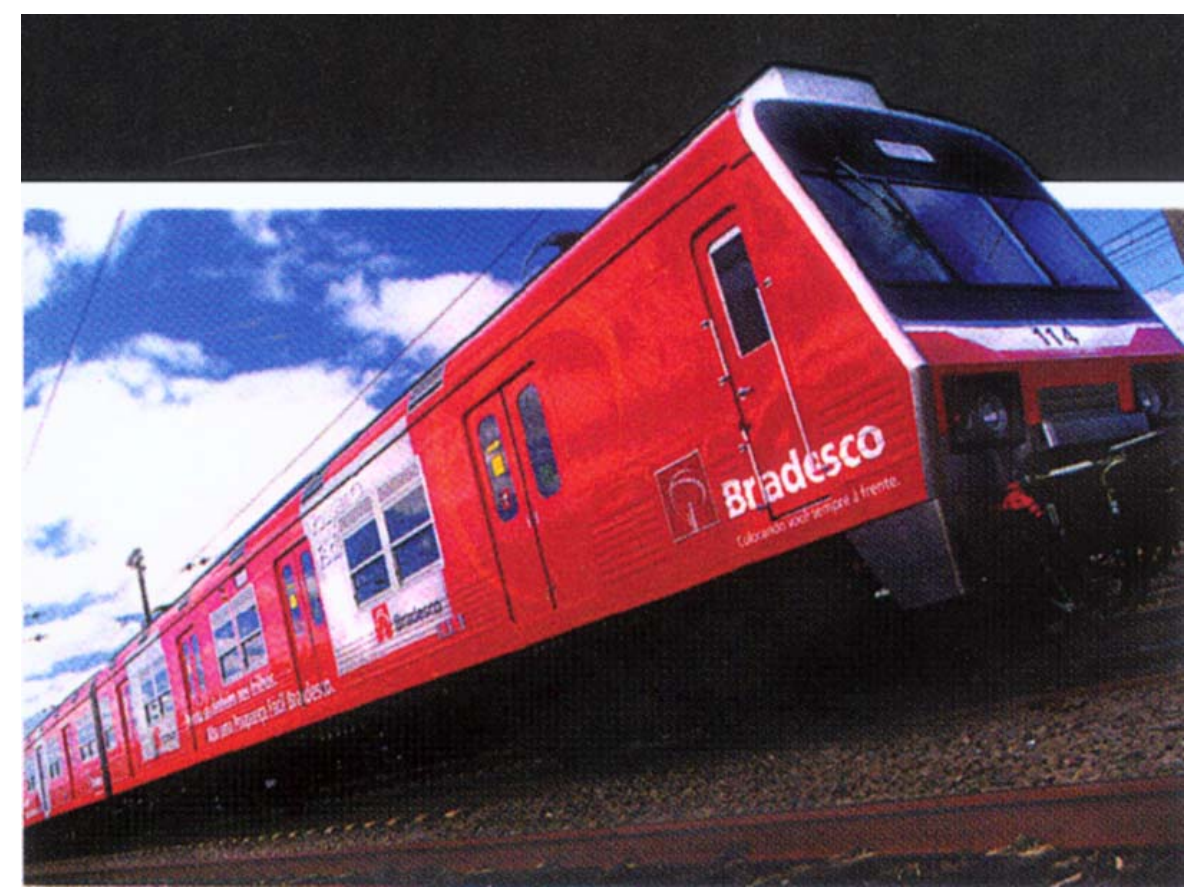

Figura 37 - "Trens"

Fonte: Jornal Meio \& Mensagem. Edição Especial. Mídia Exterior, 19 mar. 2001. 
- Embarcações

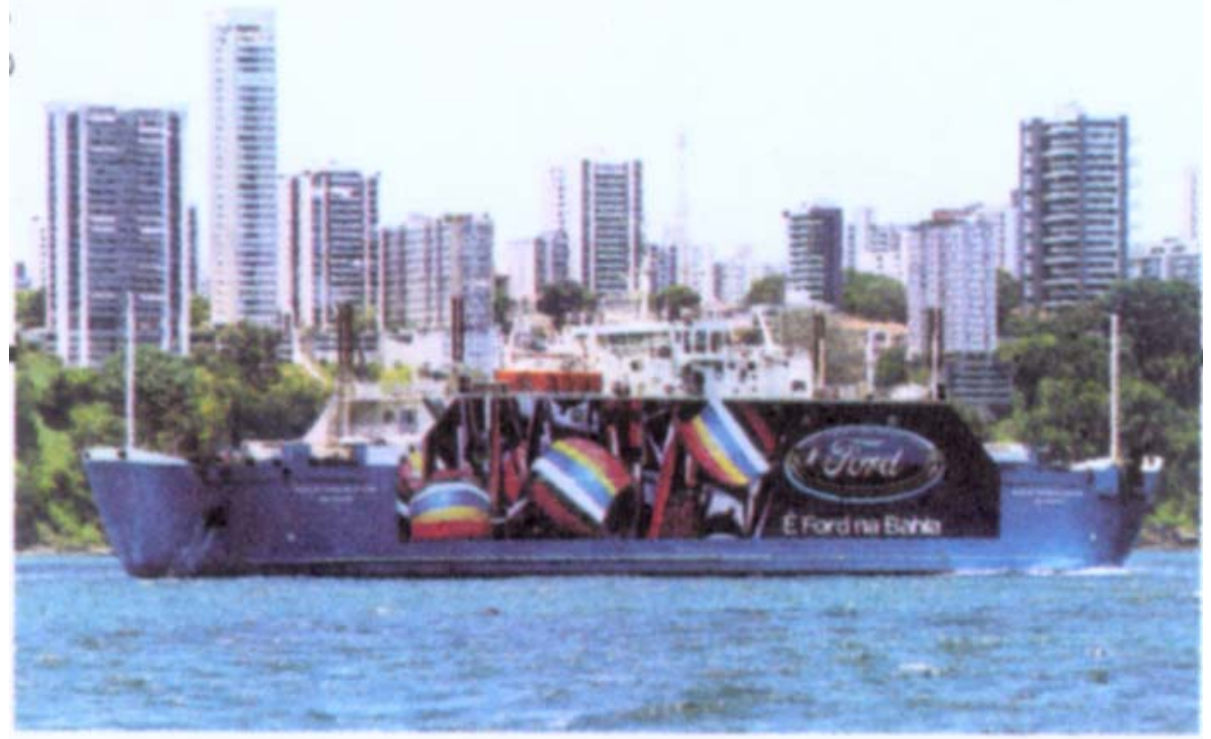

Ferry Boat: nova alternativa de mídia e ícone baiano atrai atenção dos anunciantes

\section{Figura 38 - "Embarcações"}

Fonte: Jornal Meio \& Mensagem. Edição Especial. Mídia Exterior, 19 mar. 2001.

- Aviões

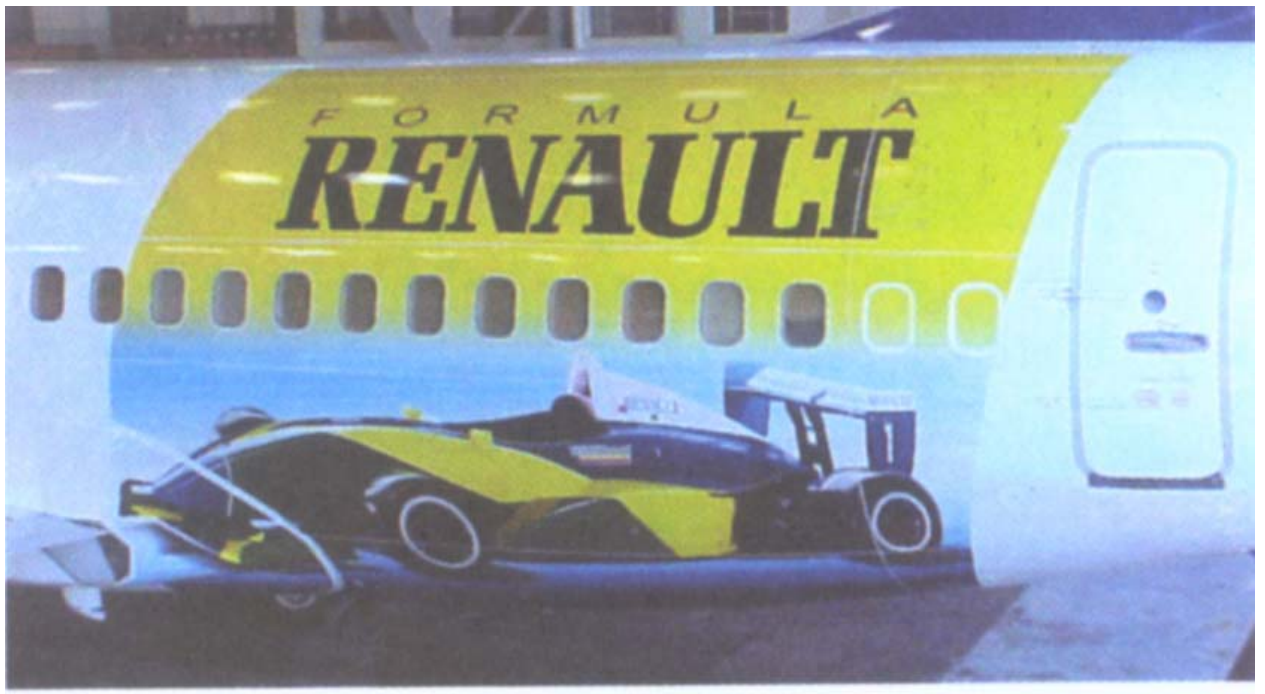

Campanha Renault: novos canais de comunicação

Figura 39 - "Aviões"

Fonte: Jornal Meio \& Mensagem. Edição Especial. Mídia Exterior, 14 out. 2002. 
- Motos

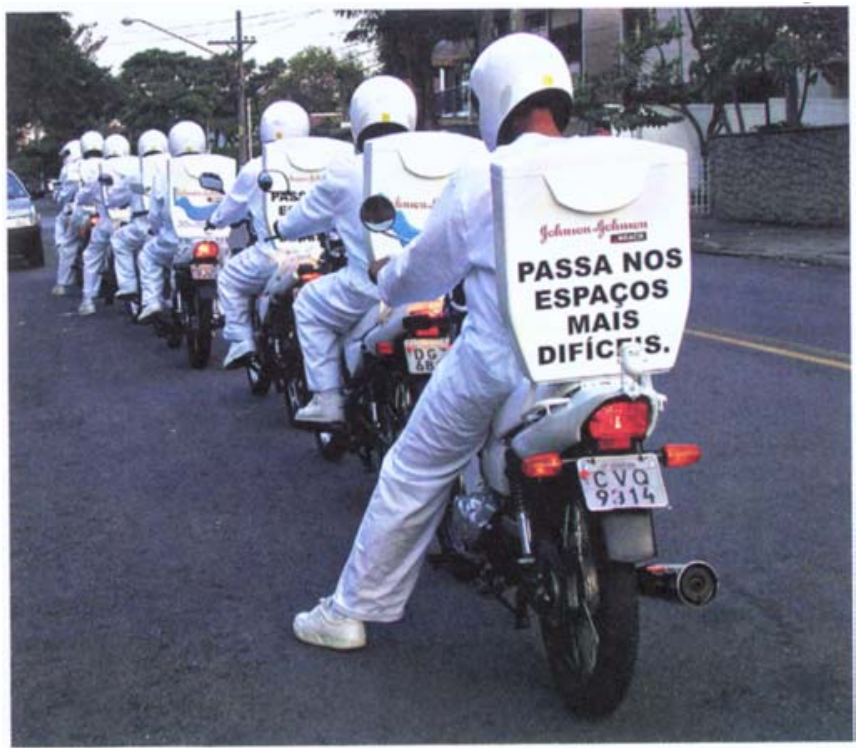

Campanha Reach, da Johnson\&Johnson, trabalho da DPZ: mídia móvel com verba timitada

\section{Figura 40 - "Motos"}

Fonte: Jornal Meio \& Mensagem. Edição Especial. Mídia Exterior, 14 out. 2002.

- Abrigo de árvore

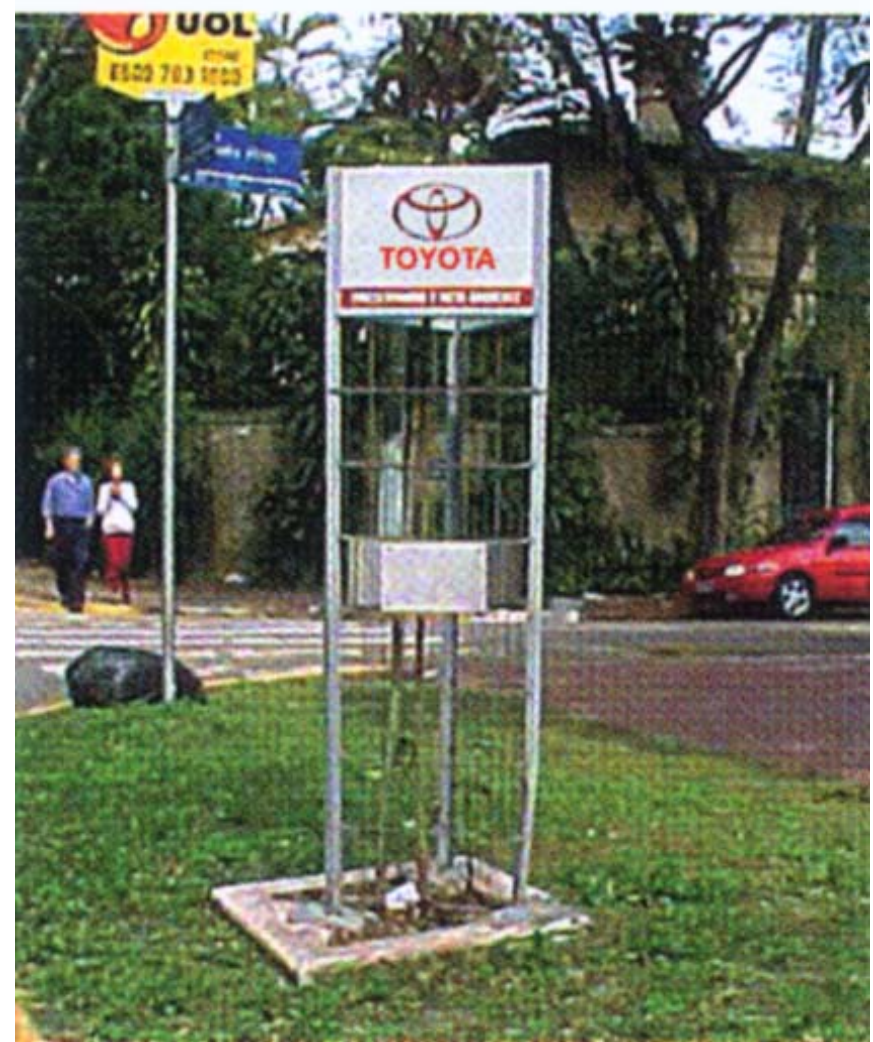

Figura 41 - "Abrigo de árvore"

Fonte: Jornal Meio \& Mensagem. Edição Especial. Mídia Exterior, 14 out. 2002. 
- Faixas puxadas por aviões

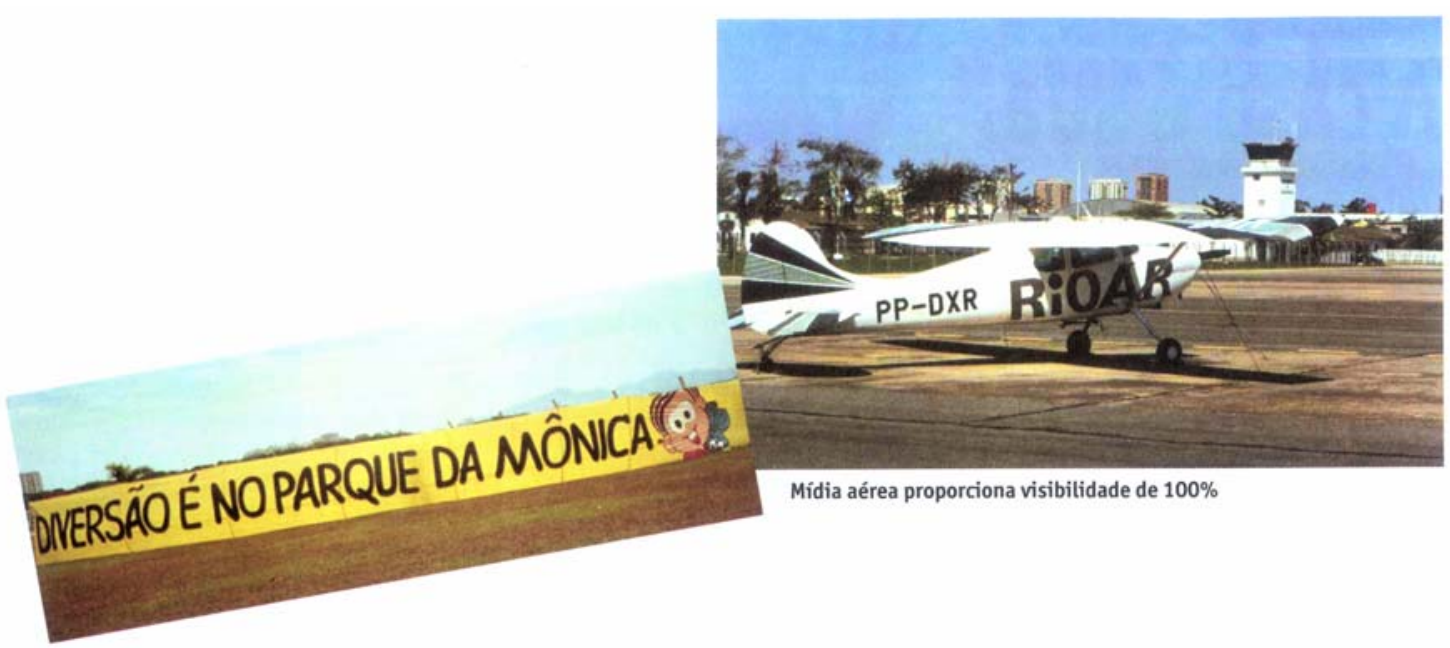

Figura 42 - "Faixas puxadas por aviões"

Fonte: Jornal Meio \& Mensagem. Edição Especial. Mídia Exterior, 14 out. 2002.

- Balões de gás.

- Balões em superfície de água.

- Jangadas.

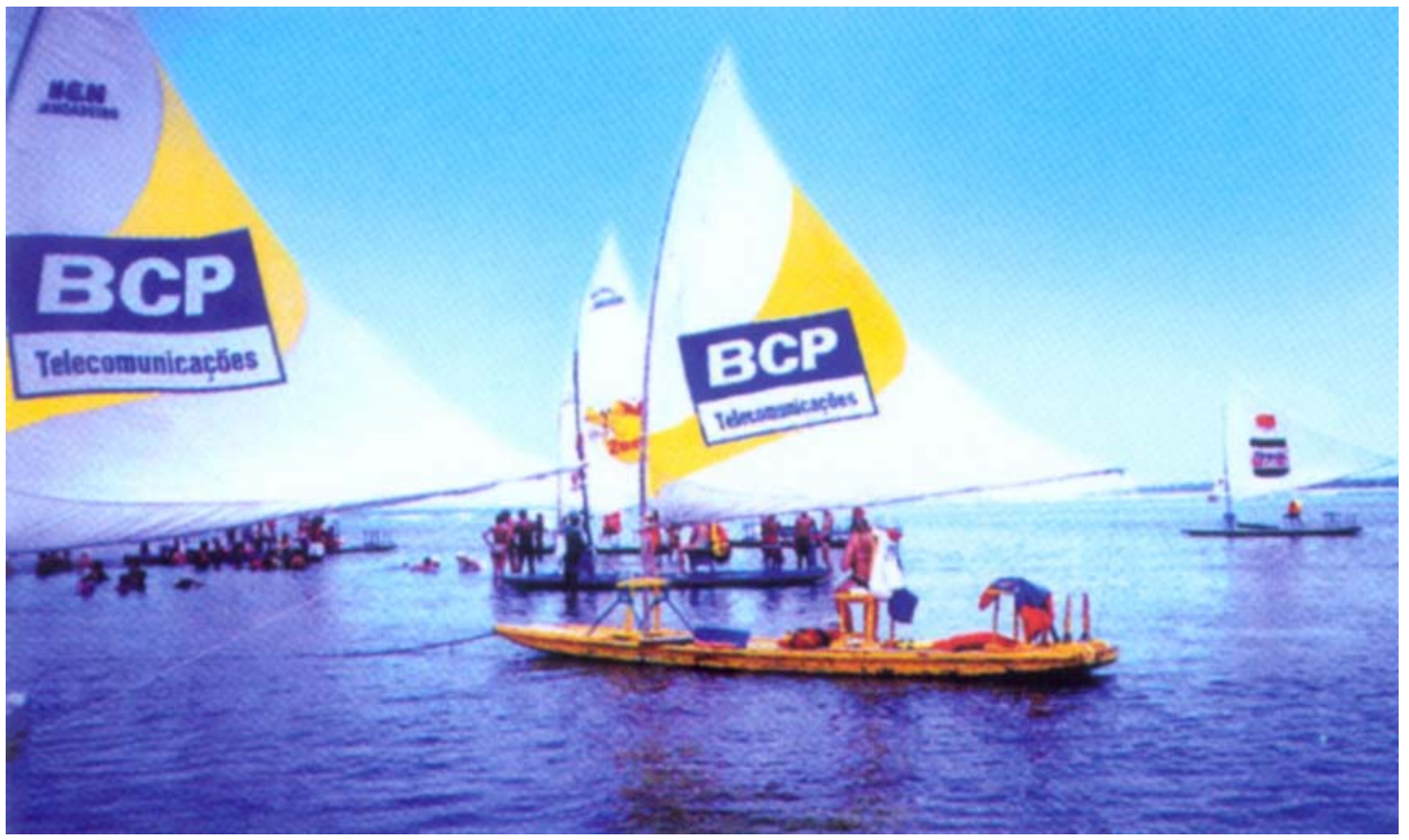

Figura 43 - "Jangadas"

Fonte: Folder Comercial da Mída Plus - Anexo 
- Semáforo.s

- Lixeiras.

- Painel de proteção para pedestre.
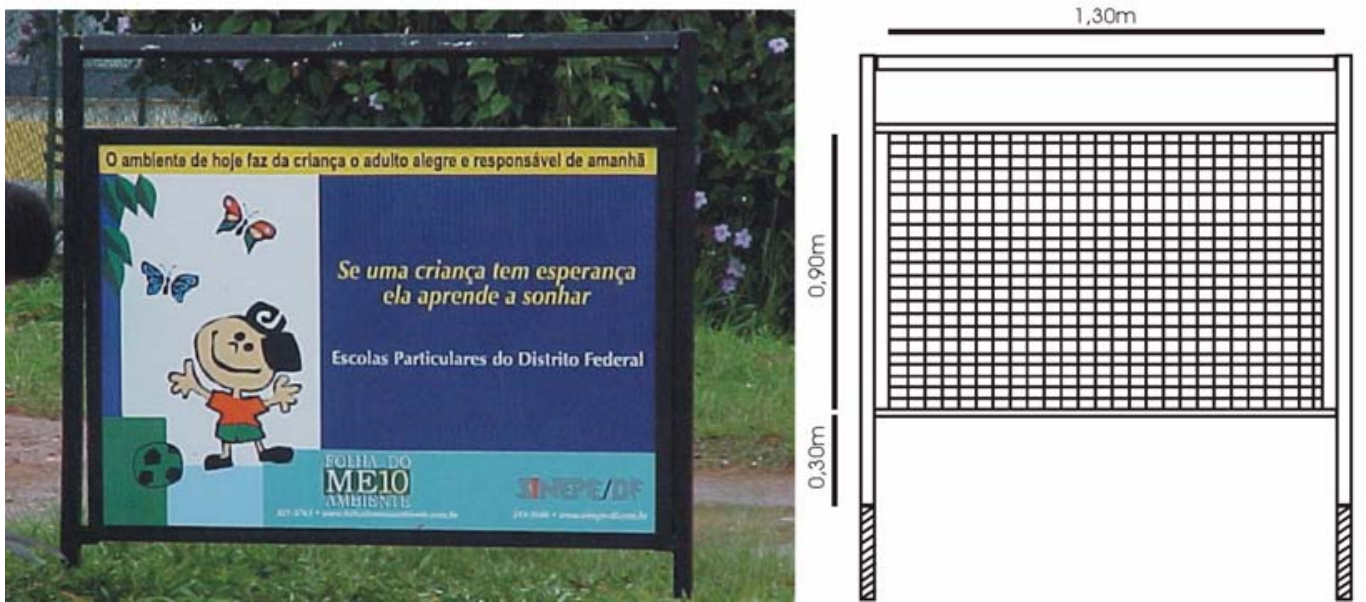

Figura 44 - "Painel de proteção para pedestre"

Fonte: Manual de Informações Técnicas da Nova Mídia Visuplac

- Ponto de ônibus.

- Painéis de endereçamento.

- Painéis de estrada.

- Painéis de estrada / pedágios.

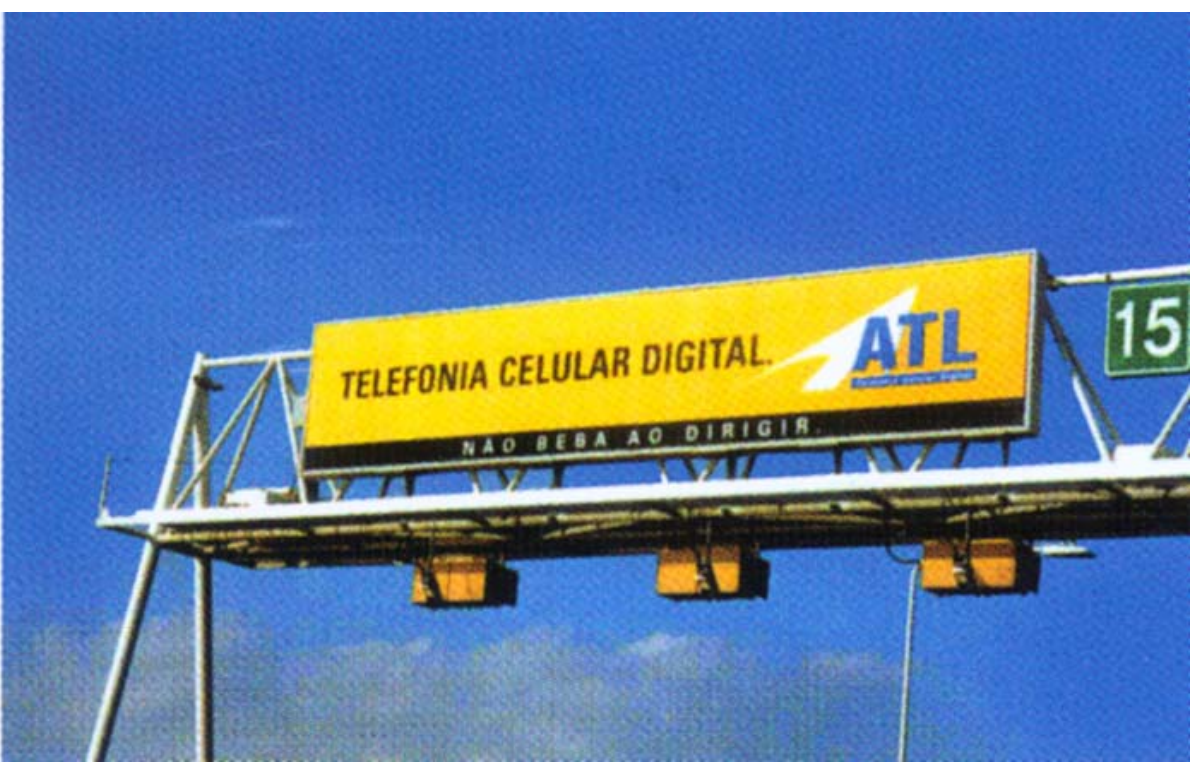

Figura 45 - "Pedágios"

Fonte: Folder Comercial da Mídia Plus. Anexo. 
- Cabine Telefônica

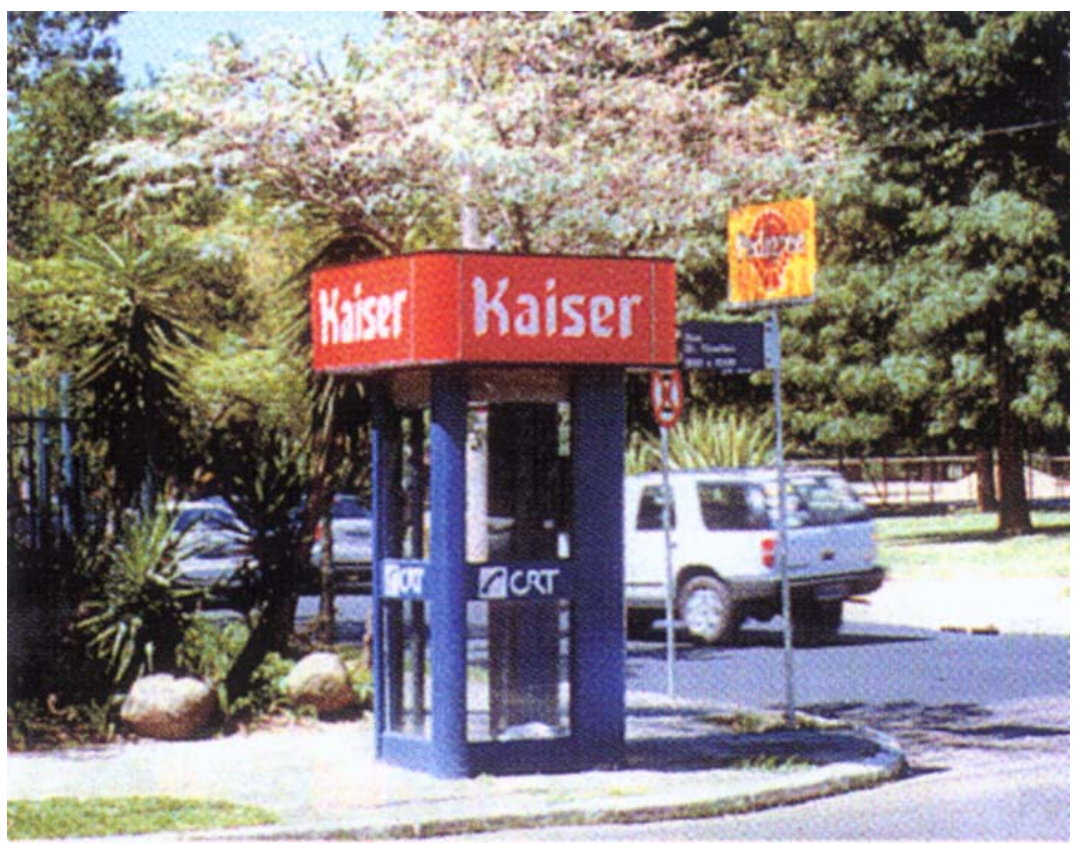

Figura 46 - "Cabine telefônica"

Fonte: Folder Comercial da Mídia Plus - Anexo.

Os engenhos publicitários que aqui se recomenda para o estímulo da prática do ecoturismo são aqueles que de fato estejam integrados às paisagens onde os mesmos estão localizados. Para expor alguns exemplos, citam-se os Back-Lights ou Front-Lights instalados em áreas verdes, próximos a lagos, em estradas, ou mesmo em vias públicas, onde não estejam agredindo ou estejam em dissonância com a paisagem.

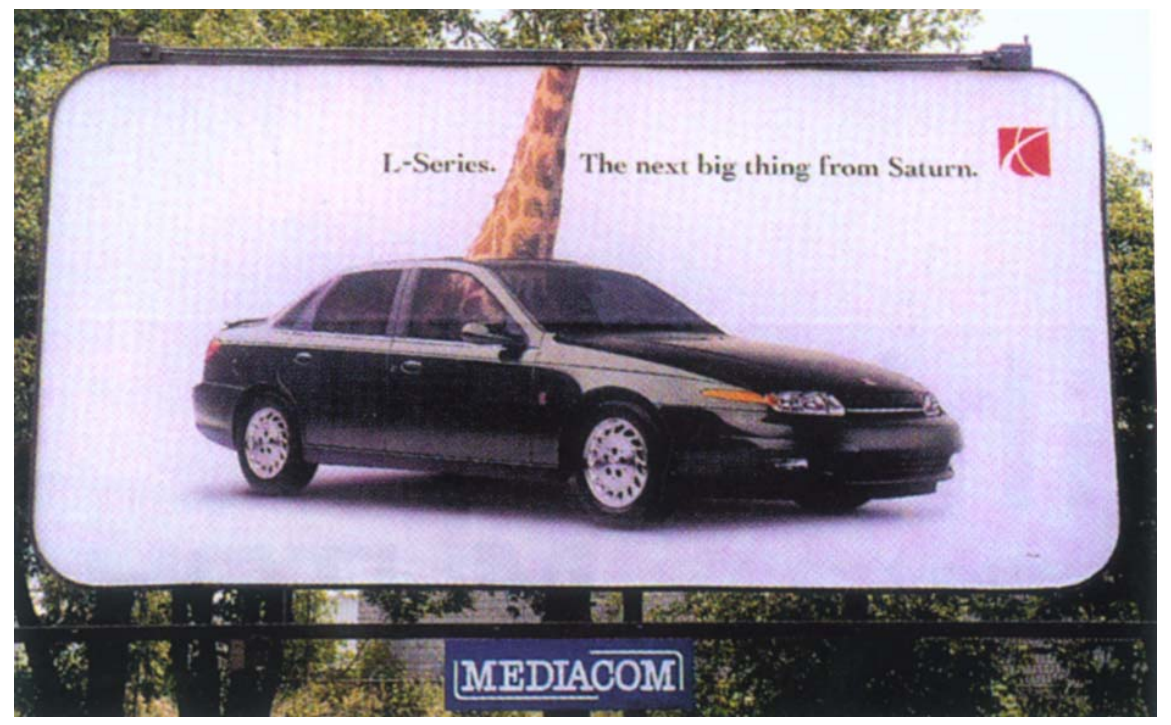

Figura 47 - "Back-Light Girafa" - Possibilidade de integração com a paisagem natural

Fonte: Revista Sinal Extensivo, ano 4, n. 34, set. 2000, p. 22, Mozarzel Edições e Promoções Ltda. 
Outro exemplo é a campanha feita em avião, onde a mensagem adesivada na fuselagem deste seja um estímulo à visitação de Parques Nacionais, Estaduais ou Municipais, situados nas proximidades dos destinos de partida ou chegada das rotas desses aviões. Dessa forma, o viajante "lembra-se" da oportunidade de visitar esse Parque durante o período de permanência naquele destino.

Outra real possibilidade é a de se caracterizar em engenho publicitário com "roupagem" específica para a mensagem de educação ambiental. Por exemplo, plantando uma "trepadeira" ao pé de Front-Lights, Outdoors, Back-Lights ou demais painéis fixos que permitem esse incremento/diferencial.

Dessa forma, ficaria caracterizado o engenho com sua mensagem ambiental, diferenciando-o das demais mensagens da cidade.

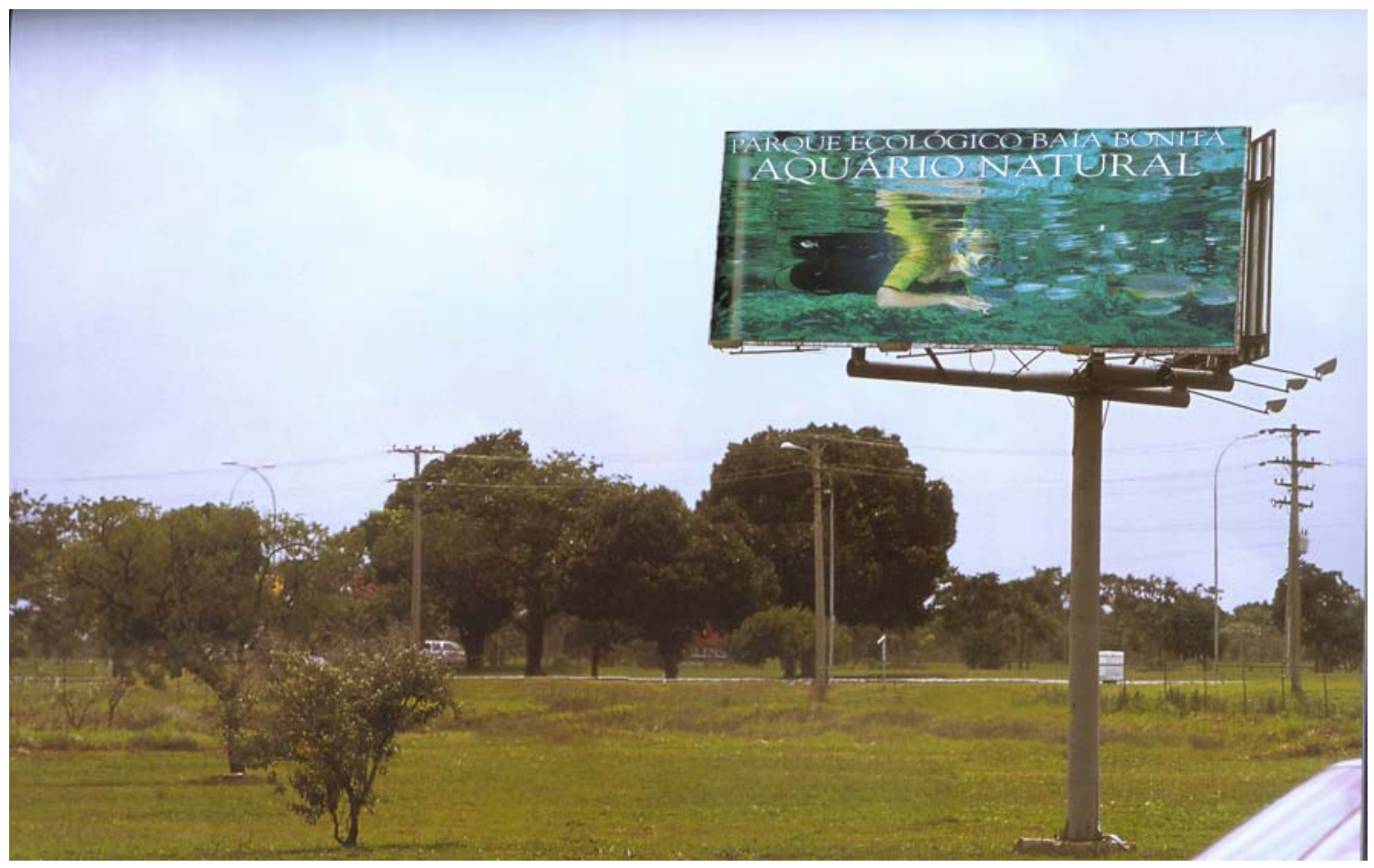

\section{Figura 48 - "Front-Light Vivo" - Possibilidade de caracterização do engenho publicitário com o meio ambiente e com a mensagem}

Fonte: Revista Portfolio Magazine, $n^{\circ}$ 1, fev. 2003, Brasília, Charbel Gráfica e Editora Ltda.

A experiência do Exército, por meio da "camuflagem", é outra fonte de inspiração à integração com a natureza. Dessa forma, o painel que inicialmente teria a pintura das estruturas metálicas em cores sóbrias como o cinza, o bronze, o chumbo e 
até o aço escovado, passaria a ser caracterizado por pinturas "camufladas", para mensagens ambientais.

Todavia, essa "nova camuflagem" teria aspecto diferente do desenho usado pelas Forças Armadas, utilizando imagens mais estilizadas, não agressivas, com estilo próprio, naturalizado ou personalizado. A própria criação da mensagem (criação publicitária com linguagem ambiental) deve se preocupar com a informação da localização onde o engenho a veicular tal mensagem está instalado, de maneira a compor o ambiente com o restante da paisagem. Assim, a integração da mensagem com e painel e com a paisagem é harmônica e poderá produzir o resultado esperado.

A sugestão é que ao mesmo tempo em que se cria a mensagem ambiental, também se caracteriza a nova "roupagem" do engenho a ser utilizado. Isso é totalmente possível pelos “apliques”. Esse é o termo técnico (dentro da publicidade) utilizado para a inclusão de qualquer elemento extra (planta trepadeira, pintura diferenciada das estruturas, complemento de foto, desenho, letra ou número), além do espaço padrão do engenho publicitário.
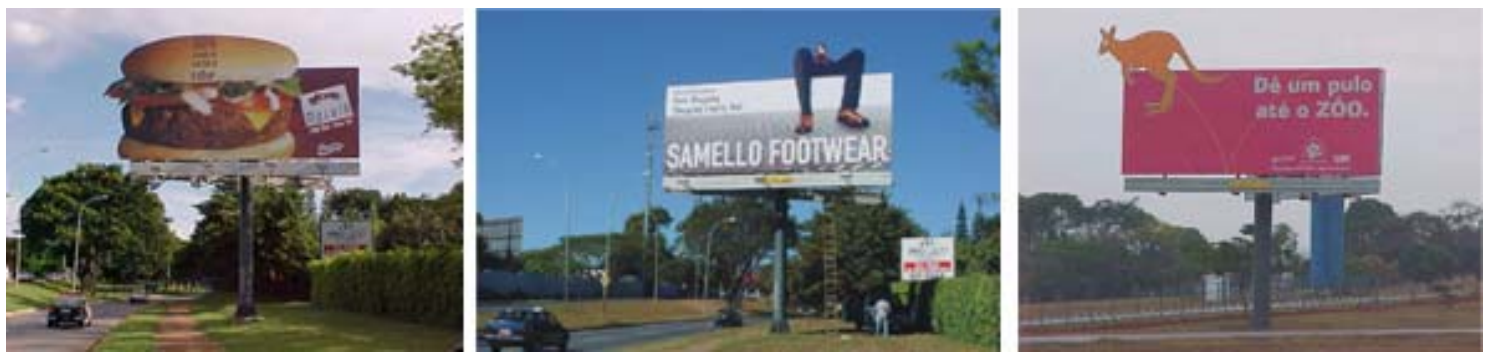

Figura 49 - "Marvim, Samello e Zôo - Brasília" - Exemplos de apliques

Fonte: Arquivo de Fotos Comprovação Nova Mídia Visuplac.

A criatividade dentro da publicidade já é algo excepcional. Inspirada na natureza ou em temas ambientais, aliadas a boas escolhas de mídia exterior e planejamentos bem pensados, as mensagens publicitárias têm a possibilidade de tornar claros, fáceis e próximos os conceitos de sustentabilidade e educação ambiental por meio da prática do ecoturismo.

O fator integração homem-natureza, proposto de forma simples e objetiva, tem na mídia exterior mais um instrumento que atinge, de maneira indistinta, qualquer camada da população. Qualquer pessoa poderá ser um agente em favor da conservação 
ambiental, conhecendo, sensibilizando e conscientizando-se a respeito dessa nova modalidade de turismo, que é o ecoturismo.

\section{9 - A Mídia ViVA}

As mídias exteriores, relacionadas e integradas com o meio ambiente, podem inspirar atitudes e comportamentos ambientalmente corretos. Ela interage com o meio externo e com o seu potencial público consumidor (ecoturista), não sendo este exatamente o consumidor urbanizado, sedento de um momento de alívio do trabalho estressante.

A mídia viva pode propor um novo comportamento social menos consumista e mais consciente de tudo que o cerca. A interação / integração dos elementos - paisagem, mídia exterior e população das cidades - dentro de mensagens educativas e ao mesmo tempo sugestivas, poderá povoar as vias públicas das cidades com um novo conceito de desenvolvimento - sustentável -, ao mesmo tempo em que, interferindo o mínimo possível nessa mesma paisagem, ou tornado-a mais agradável, mais verde, mais cristalina, mais calma e, por fim, mais consciente.

Essa integração entre a paisagem, a mídia exterior e a população das cidades pode ocorrer utilizando-se as caracterizações já citadas (e outras infinidades de apliques, que podem ser criadas) e também o que se chama de "Outdoor Vivo" ou "Mídia Exterior Viva", que consiste na participação de pessoas e "objetos vivos", dando volume e movimento a esta mídia.

Como exemplo, pode-se citar uma campanha publicitária feita em 1997, pela agência Sette,Graal, de Brasília, para uma academia de ginástica, que, em três outdoors montados na cidade, foram criados verdadeiros palcos de teatro, onde atletas/modelos foram contratados, e "encenavam" exercícios como spinning, esteira e halteres.

Se com uma academia, cujas instalações são limitadas, pôde-se propor idéia tão inédita e original, imagine-se em situações de práticas ecoturísticas? Escalada, caminhada, mergulho (um gigantesco aquário), observação de pássaros, enfim, será possível total impacto visual perante um público ocupado e apressado das cidades, porém, atento às inovações de forma, conteúdo e, por que não dizer, inovações de conceito que a mídia exterior (e dependendo da situação, mídia viva) poderá viabilizar. 


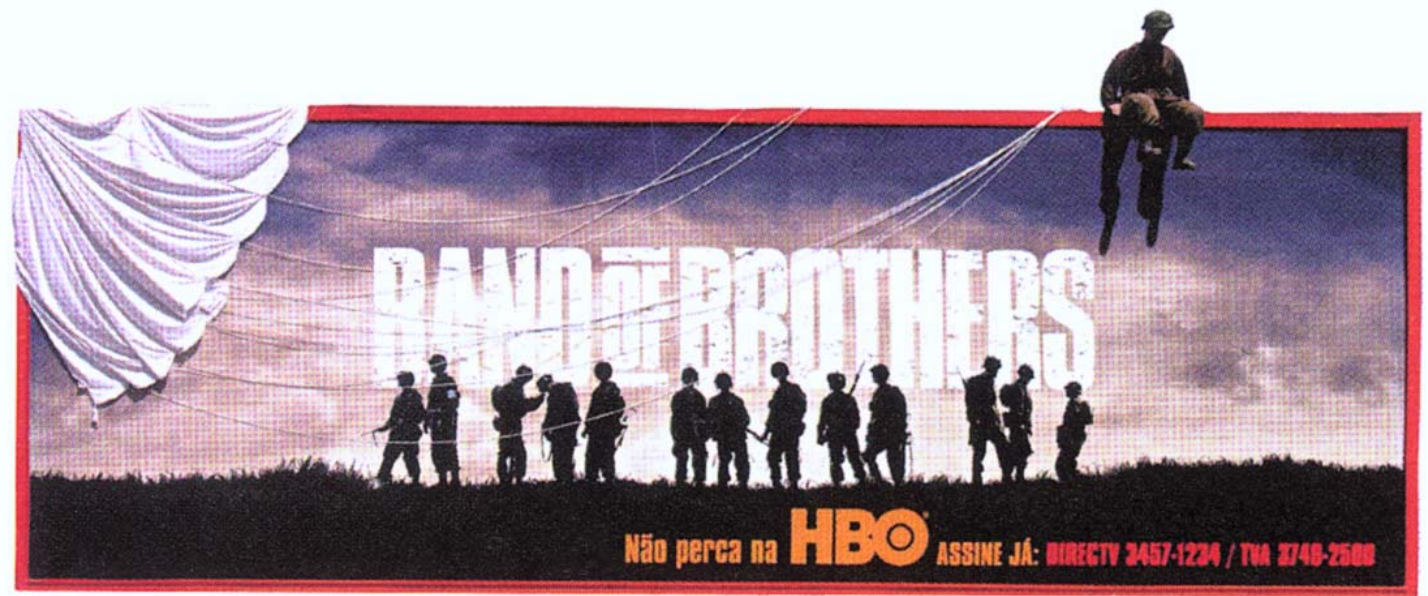

Figura 50 - "Anúncio HBO" - Exemplo de apliques "vivos"

Fonte: Jornal Meio \& Mensagem. Edição Especial. Mídia Exterior, 10 out. 2002. 


\section{CAPÍTULO 3 - 0 ECOTURISMO COMO ATIVIDADE ECONÔMICA SUSTENTÁVEL - CARACTERÍSTICAS E POSSIBILIDADES}

\section{Segundo FENNEL:}

A medição de desenvolvimento (i.e, o estágio de avanço econômico de uma nação) convencionalmente tem sido realizada por meio de aplicação de um certo número de indicadores-chave econômicos (FENNEL, 2002, p. 24).

Citando um exemplo do mesmo autor, vê-se que:

(...) tem sido observado que os $\mathbf{2 0} \%$ mais desenvolvidos da população mundial (os que estão no ocidente), supostamente usam $80 \%$ dos recursos do mundo sem os quais não se pode chegar ao desenvolvimento (idem).

Chega-se, então, a um grande paradigma, pois se a meta dos países for o "desenvolvimento" de todos os povos do planeta, de onde tirar os recursos dessa diferença? O resultado é que a sociedade não será capaz de se sustentar a longo prazo se esse modelo de desenvolvimento continuar priorizado.

Na década de 80, iniciou-se o movimento de questionamento em torno desse modelo convencional de desenvolvimento. Assim, o termo desenvolvimento sustentável começou a ser discutido e proposto em inúmeros congressos e conferências internacionais:

O desenvolvimento sustentável foi proposto como um modelo que pode ser útil na criação do estímulo para a mudança estrutural da sociedade, um modelo que deverá se desviar de um foco estritamente socioeconômico para outro diferente, em que o desenvolvimento "alcance as metas do presente sem comprometer a capacidade das futuras gerações de satisfazer as suas próprias necessidades" (Comissão Mundial de Meio Ambiente e Desenvolvimento, 1987, p. 43).

O turismo, reconhecido como importante segmento econômico de crescimento e desenvolvimento, começa então a ser destacado como uma oportunidade relevante para o desenvolvimento sustentável.

Segundo Fennell, na Conferência Globo de 1990, as metas do turismo sustentável foram definidas da seguinte forma: 
(1) desenvolver maior consciência e compreensão das contribuições significativas que o turismo pode trazer ao meio ambiente e à economia; (2) promover a eqüidade e o desenvolvimento; (3) melhorar a qualidade de vida de comunidade anfitriã; (4) oferecer experiências de alta qualidade para o visitante; e (5) manter a qualidade do meio ambiente do qual dependem os objetivos anteriores (FENNEL, 2002, p. 26).

A partir daí, o turismo sustentável passou por diversas discussões e o ecoturismo surgia, dentro desse contexto, como uma modalidade desse novo tipo de turismo.

Segundo a definição de Wallace \& Pierce, o ecoturismo é:

A viagem a áreas naturais relativamente intocadas, para o estudo, o divertimento, ou a assistência voluntária. É a viagem em que há preocupação com a flora, a fauna, a geologia e os ecossistemas de uma área, assim como com as pessoas (guardiãs) que vivem nas vizinhanças, suas necessidades, sua cultura e seu relacionamento com a terra. $O$ ecoturismo encara as áreas naturais como "a casa de todos nós" num sentido global ("eco" significa "casa"), mas também especificamente a "casa dos habitantes das vizinhanças". Ele é visto como uma ferramenta para a conservação e o desenvolvimento sustentável - especificamente nas áreas onde a população local é solicitada a abrir mão do uso predatório dos recursos naturais em favor de outros tipos de uso (FENNELL, 2002, p. 49, apud WALLACE \& PIERCE, 1996, p.848).

Com essas características, as possibilidades de mercado são inúmeras, pois com o aumento da divulgação dos passeios turísticos em áreas naturais no Brasil, com o despertar do desejo de passeios mais calmos e com o estímulo ao retorno à natureza, uma considerável parte dos turistas tradicionais, ou os chamados turistas "de massa", tem migrado para o ecoturismo.

Uma grande quantidade de pessoas que antes nunca pensava em passear em fazendas, Parques Nacionais ou mesmo em áreas do interior do País, com belíssimos rios, cachoeiras, grutas trilhas, etc, agora já está programando as férias com suas famílias para estes locais.

Dessa forma, têm surgido inúmeros empreendimentos particulares, além dos Parques Nacionais, que, de forma gradativa, vêm se abrindo à visitação pública mediante o pagamento de um ingresso, além de outras atrações.

Pode-se dizer que o ecoturismo ainda está longe de ser praticado da forma como é definido, todavia, diante do aumento de consciência da população, que está atenta às mudanças ambientais do planeta, e preocupando-se em contribuir com sua 
parte para a manutenção do equilíbrio dos ecossistemas, essa atividade econômica sustentável tem toda a possibilidade de sucesso.

Para isso os agentes envolvidos (governos, empresários de turismo, terceiro setor, comunidades envolvidas e o próprio ecoturista) precisam se integrar em um mesmo objetivo, fortalecendo-se para, finalmente, crescer e se desenvolver dentro desse novo modelo de economia, que é a sustentabilidade. 


\section{CAPÍTULO 4 - A EDUCAÇÃO AMBIENTAL COMO LINGUAGEM E ARGUMENTO PARA A SENSIBILIZAÇÃO E CONQUISTA DO PÚBLICO PARA A PRÁTICA DO ECOTURISMO}

A educação ambiental tem a seguinte definição, conforme estabelecido na Lei Federal no 9.795, de 27/04/99:

Art. $1^{\circ}$. São os processos por meio dos quais o indivíduo e a coletividade constróem valores sociais, conhecimentos, habilidades, atitudes e competências voltadas para a conservação do meio ambiente, bem de uso comum do povo, essencial à sadia qualidade de vida e sua sustentabilidade.

A educação ambiental possui inúmeras possibilidades de ser realizada. Por exemplo, por meio da educação formal, nas escolas; pela interpretação ambiental, nos Parques e nos diversos tipos de empreendimentos ecoturísticos, podendo também ser introduzida por meio da educação informal, pela via dos meios de comunicação, os quais são agentes mobilizadores e difusores de mensagens conceituais.

A linguagem da educação ambiental se caracteriza principalmente pela participação da população na formação da mesma (“o indivíduo e a coletividade constróem valores sociais, conhecimentos, habilidades, atitudes e competências voltadas para a conservação do meio ambiente").

Dessa forma, a educação ambiental voltada para o ecoturismo deve propor principalmente um despertar para a visita ao ambiente natural, praticando comportamentos que visem a conservação desse ambiente.

Esses "novos" comportamentos e atitudes não acontecem de uma hora para outra. Eles necessitam de uma lembrança, um estímulo constante, para que possa se tornar um hábito. 


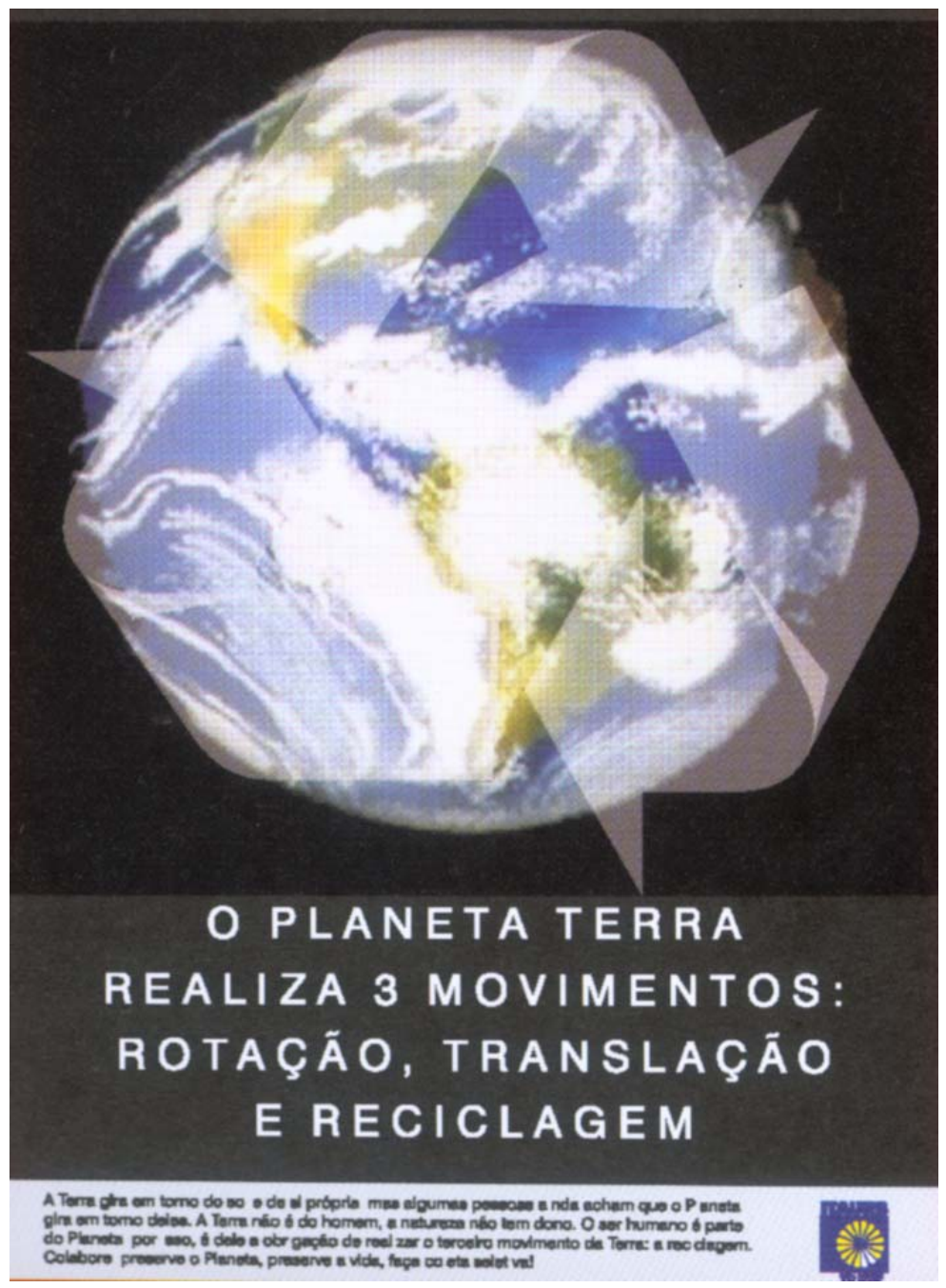

\section{Figura 51 - "Anúncio reciclagem"}

Fonte: Revista About. Edição Especial. Portfolio, 2002/2003, Versart Editora Artes e Comunicação Ltda.

Pode-se afirmar que a linguagem da educação ambiental deve utilizar a simplicidade, ser construtiva, informativa e de explicações concisas, ao contrário da negativa, ou da proibição pura e simplesmente.

Se a proibição for necessária, os motivos devem ser explicados, de preferência citando exemplos. Por meio desse argumento de explicações simples e de exemplos práticos, será possível utilizar a mídia exterior, que, por intermédio do seu know-how, tem a possibilidade de atingir e sensibilizar um grande número de pessoas dos centros urbanos para iniciar a prática do ecoturismo, construindo valores sociais capazes de gerar mudança de atitude e comportamento, voltando as atenções para a conservação do meio ambiente. 


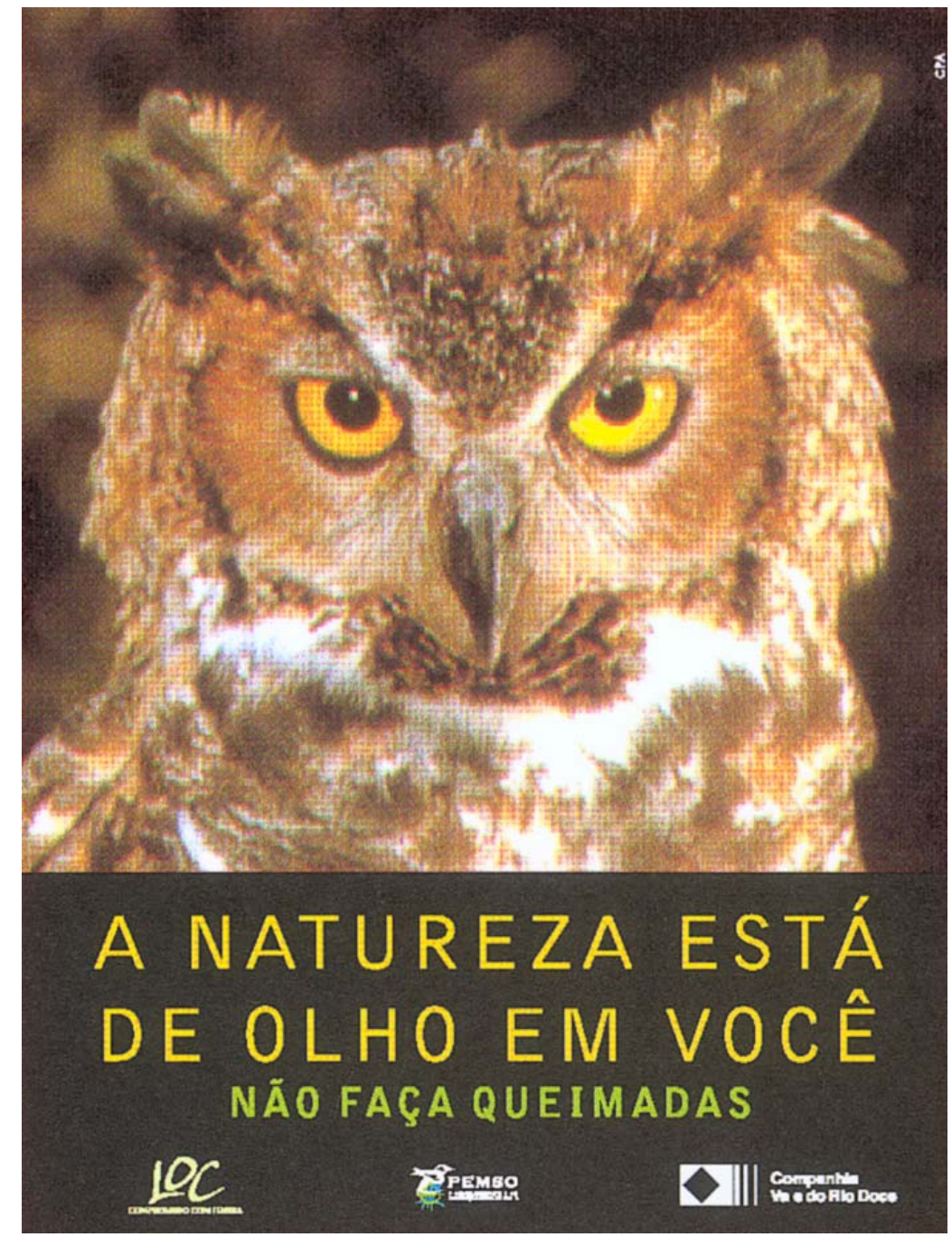

Figura 52 - "Anúncio Queimadas"

Fonte: Revista About. Edição Especial. Portfolio, 2002/2003, Versart Editora Artes e Comunicação Ltda.

Quando as mensagens veiculadas nesda mídia têm caráter educativo ambiental, existe então a possibilidade de uma sinergia entre o ambiente, o expectador e a mídia. 


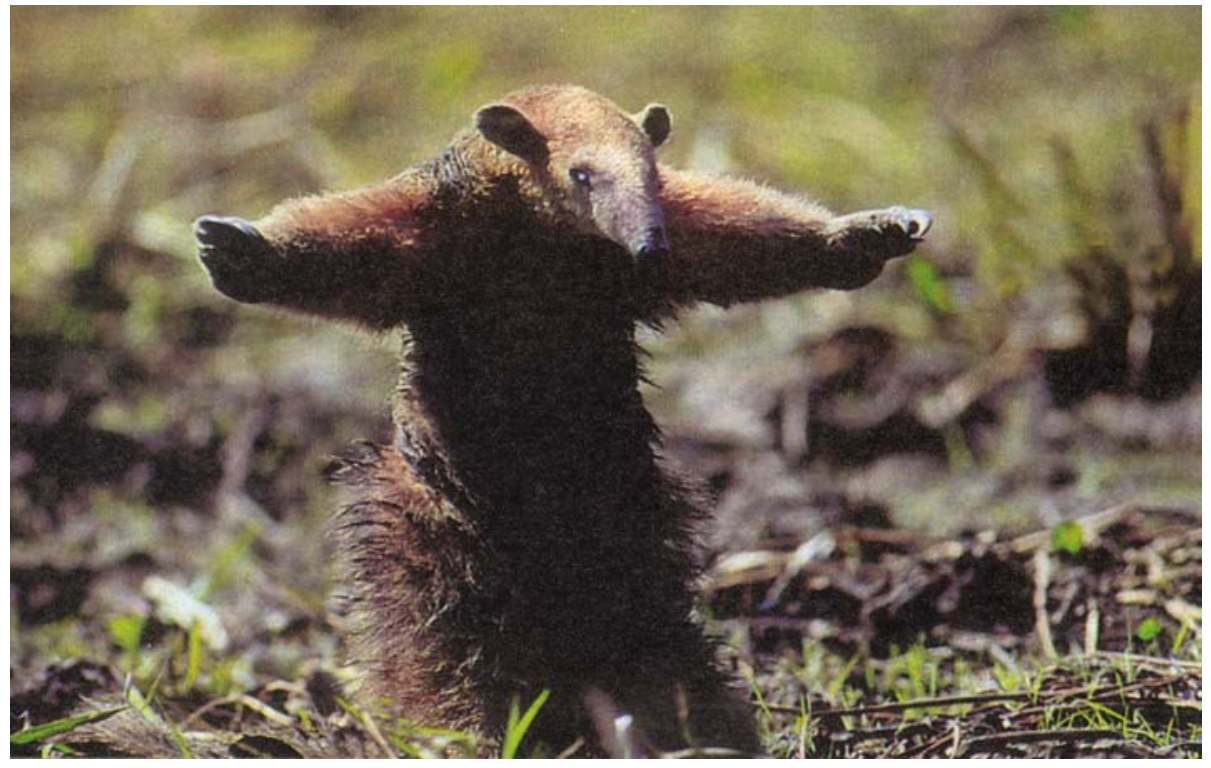

Figura 53 - "Tamanduá" - Exemplo de linguagem simples e direta, com inspiração na natureza

Fonte: Ecologia. Revista Veja, ano 35. Edição Especial, n. 22, dez 2002, Editora Abril.

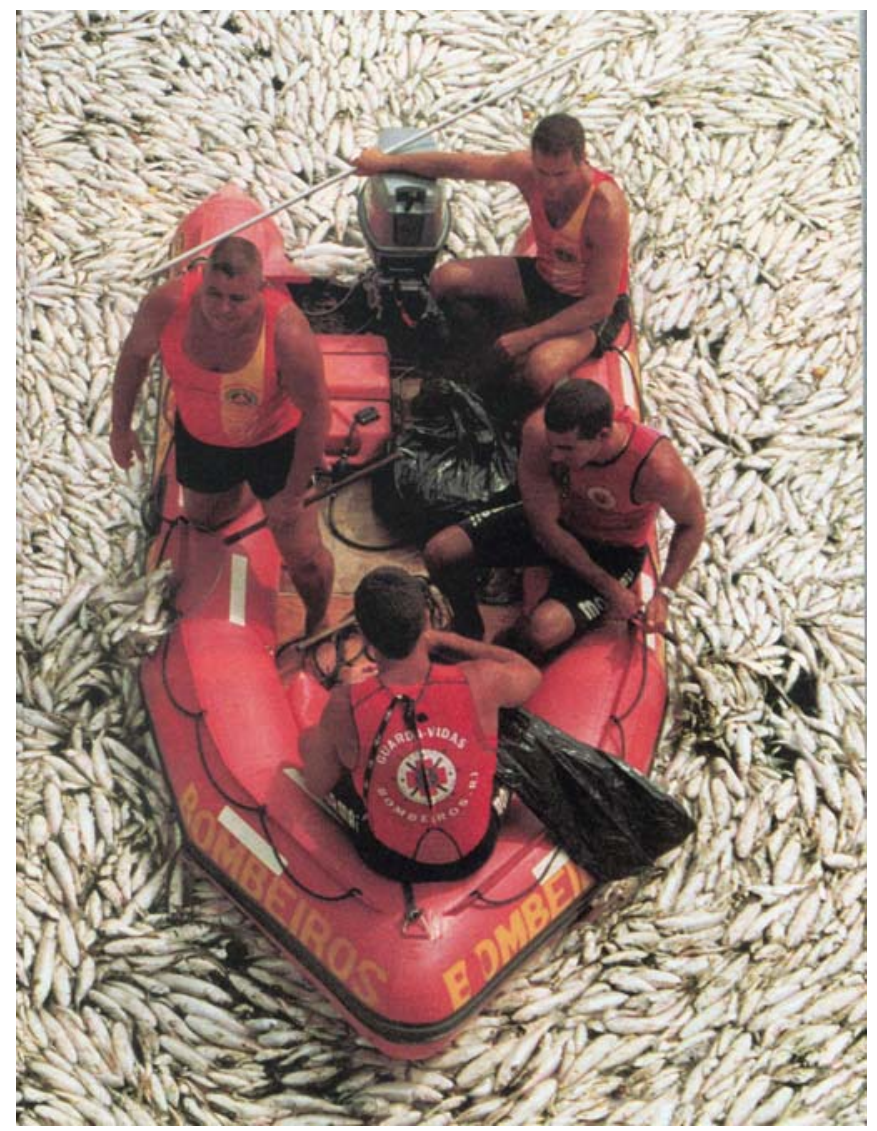

Figura 54 - "Peixes" - Exemplo de linguagem de impacto e direta

Fonte: Ecologia. Revista Veja, ano 35. Edição Especial, n. 22, dez 2002, Editora Abril. 


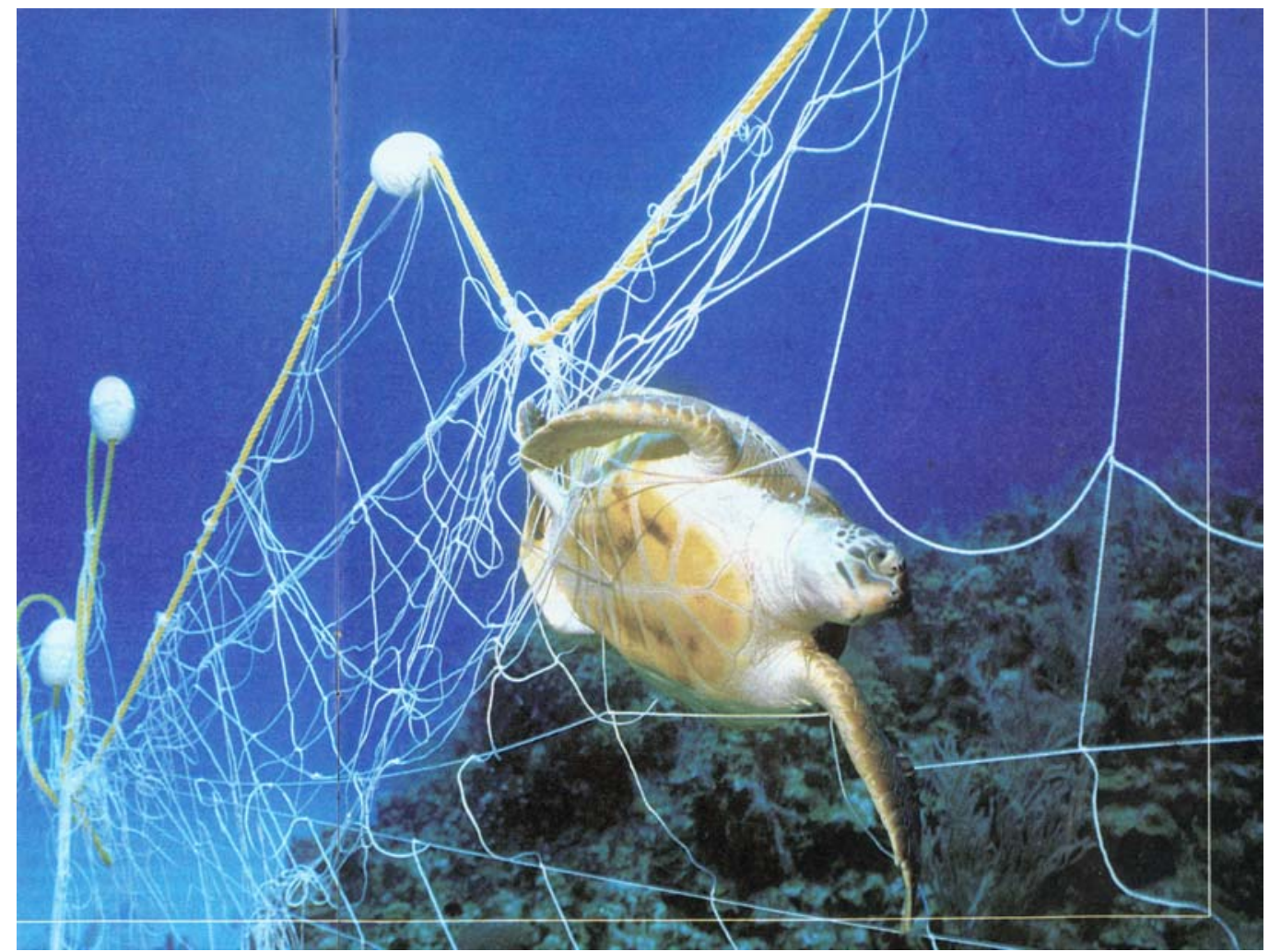

Figura 55 - "Tartaruga" - Exemplo de linguagem de impacto e direta

Fonte: Ecologia. Revista Veja, ano 35. Edição Especial, n. 22, dez 2002, Editora Abril. 


\section{CAPÍTULO 5 - A MÍDIA EXTERIOR COMO POSSIBILIDADE DE CRIAÇÃO de CONSCIÊNCIA PÚBLICA SOBRE A PRÁTICA DO ECOTURISMO, ATRAVÉS DE PARCERIAS COM ENTIDADES AFINS NOS MESMOS INTERESSES MERCADOLÓGICOS DE ATUAÇÃO}

Com a exposição de notícias nos principais meios de divulgação, como desastres ecológicos, poluição de rios e mares, uso exagerado e descontrolado de agrotóxicos e industrialização sem controle ambiental, a população das cidades começa a se sensibilizar pela questão ambiental. Já existe uma crescente consciência governamental e empresarial a respeito do desenvolvimento sustentável.

Segundo estudos recentes do SEBRAE:

Em poucos anos os valores ambientais evoluíram de um interesse marginal para o topo das preocupações, principalmente dos consumidores no mundo ocidental mais desenvolvido. Preocupadas em proteger a vida no planeta, as pessoas resolveram agir nas lojas e nas prateleiras de supermercados, optando por produtos considerados ambientalmente saudáveis e rejeitando aqueles que não oferecem essa garantia. Isso que chamamos de "consumerismo ambiental" provoca uma reviravolta no marketing e cria novos nichos de mercado com oportunidades de negócios. Tendência presente entre nós, como país em desenvolvimento, e que fatalmente se consolidará.

Pesquisas realizadas nos Estados Unidos e no Brasil e divulgadas em publicação do SEBRAE $^{1}$, mostram como é crescente a preocupação com a questão ambiental, comparada a outras questões prioritárias como economia, déficit habitacional, educação, entre outras.

Amparados nessa lenta, porém crescente conscientização do seu mercado potencial, as empresas estão alterando suas estratégias de marketing e redirecionando parte dos seus investimentos ao chamado marketing social. Além dos benefícios materiais resultantes dessas ações de conscientização mútua, existem as recompensas institucionais das marcas, que passam a ser reconhecidas como marcas de empresas progressistas.

\footnotetext{
${ }^{1}$ A questão ambiental e as empresas, SEBRAE, p.93-102, 1998.
} 
Por intermédio da parceria com ONGs, ou entidades beneficentes de um modo geral, as empresas de varejo, por exemplo, têm dado os seus passos nesse sentido.

Segundo Paulo Ricardo Meira:

As lojas Renner empreenderam o lançamento de uma coleção de roupas com a marca "Greenpeace", talvez a ONG mais conhecida mundialmente; o Detran do Rio Grande do Sul oferece postos de trabalhos a apenados em processo de reinserção social; a Levi's norte-americana destina 250 mil dólares anuais a programas de controle da AIDS no Brasil; as Faculdades Ritter dos Reis promovem leitura de contos para detentas de penitenciária feminina e crianças socialmente excluídas; a Pirelli ensina famílias no Acre a melhor retirar a seiva das seringueiras e, assim, zela por sua preservação. O Shopping Center Porto Alegre Iguatemi possui um evento chamado "Cubra o Mundo de Verde" realizado em parceria com a Riocell. Este evento tem 19 anos e é um ano mais velho do que o próprio Shopping (primeiro foi feito, em 1982, junto ao canteiro de obras, sete meses antes da inauguração do Shopping, com a intenção de fazer as pessoas irem até lá e conhecer a construção "deste tal de Shopping") foram distribuídas uma média de 100/110.000 mudas de árvores todos os anos. Em 1989 foi introduzida a distribuição de mudas de folhagens, para não excluir as pessoas que moram em apartamento $^{2}$.

Inúmeros são os exemplos de marketing social já realizado no Brasil e em outros países. Esse movimento tem se estendido das grandes indústrias para as empresas, do varejo, e tem crescido notadamente. A comunicação empresarial tem aproximado cada vez mais as marcas institucionais aos seus clientes, tendo sido o marketing social uma ferramenta estratégica de posicionamento que associa uma empresa ou marca a uma questão ou causa social relevante, em benefício mútuo.

Segundo Pringle \& Thompson, um programa de marketing voltado para causas sociais pode ser desenvolvido de duas formas: por meio de uma aliança estratégica entre uma empresa e uma organização voluntária, ou beneficente, comprometidas com a área de interesse social definida pela empresa, ou diretamente em benefício da causa em si.

Vários são os temas escolhidos para se desenvolver o marketing social de uma empresa. No caso deste trabalho, cujo objetivo principal é a promoção da prática do ecoturismo por meio da criação de consciência pública, por intermédio da mídia exterior, serão abordados exemplos de empresas que têm interesse mercadológico no mesmo perfil de público do ecoturismo.

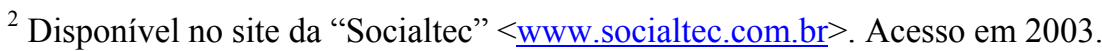


Seguem alguns exemplos de empresas que, entende-se, tem possibilidade e disponibilidade de dirigir parte dos seus investimentos em campanhas de criação de consciência pública, abraçando uma questão (educação ambiental) ou causa social relevante (exemplo: melhoria de vida de comunidades anfitriãs), com o objetivo de formar uma aliança estratégica com os agentes envolvidos tanto na atividade ecoturística, quanto no segmento da propaganda, em benefício mútuo:

\section{$\checkmark$ Indústria fotográfica}

A atitude de se levar apenas imagens de ambientes naturais, deixando sua flora, fauna e geologia intactos, são o resultado de uma consciência ambiental bem feita.

A indústria fotográfica tem a seu favor toda a inspiração visual da natureza para desenvolver a mensagem adequada a essa questão.

$\checkmark$ Parques Nacionais; empreendimentos ecoturísticos; agências e operadoras de turismo; locadoras de automóveis e empresas de transporte (rodoviário, marítimo e aéreo)

Entende-se que é de total interesse dos dirigentes dos Parques Nacionais e dos empresários de ecoturismo que a sua atividade seja comunicada ao público de forma correta, com consciência ambiental, respeito e, ao mesmo tempo, divulgando os conceitos específicos desse segmento do turismo, que ainda é pouco conhecido e principalmente pouco entendido, até mesmo pelo seu público potencial.

$\checkmark$ Governos Federais, Estaduais e Municipais (MMA, IBAMA, EMBRATUR, Secretarias de Turismo e Meio Ambiente)

Esse talvez seja um dos principais investidores interessados na promoção da prática do ecoturismo, pois será possível colocar em prática os conceitos dessa modalidade turística, promovendo o desenvolvimento sustentável de todos os agentes envolvidos. 


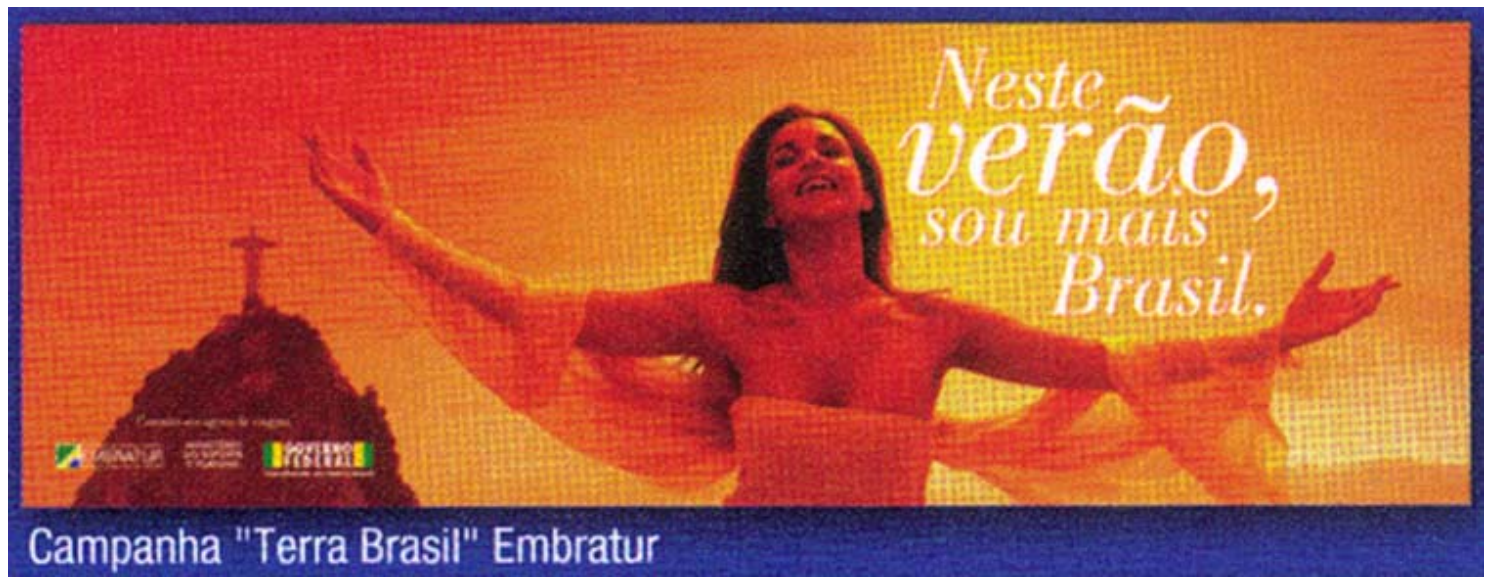

Figura 56 - "Campanha Terra Brasil" - Exemplo do interesse do governo federal em divulgar o turismo interno

Fonte: Revista About. Edição Especial. Portfolio, 2002/2003, Versart Editora Artes e Comunicação Ltda.

\section{$\checkmark$ SEBRAE, associações comerciais e cooperativas}

Já existe dentro do SEBRAE todo um esforço de sensibilização e preparação das comunidades com potencial ecoturístico. Existe o interesse no desenvolvimento de pequenas empresas comerciais respeitando o meio ambiente, fonte principal de sustentação para essa atividade turística.

\section{$\checkmark$ Terceiro setor}

Esse setor demonstra, por meio de vários exemplos, ser o mais consciente com relação aos conceitos de ecoturismo. Dessa forma, pode ser um grande articulador no que se refere às estratégias de marketing social das empresas. Ele próprio tende a ser um potencial agrupador de investimentos para a divulgação responsável e sensibilização da prática do ecoturismo.

$\checkmark$ Indústria de roupas e acessórios específicos para a prática de esportes de natureza (mergulho, rappel, escalada, caminhada, rafting, camping, bicicletas); indústria da moda; indústria náutica; indústria alimentícia de cereais e demais alimentos dirigidos ao público que pratica esportes; indústria de bebidas isotônicas e até engarrafadoras de água mineral 
Todas essas empresas têm a possibilidade de ampliar e destacar a visibilidade de suas marcas, relacionando-as com atitudes responsáveis da população perante a natureza. Apoiando as questões ou causas sociais (educação ambiental, desenvolvimento sustentável, conservação do patrimônio e melhoria do bem-estar das populações) e utilizando-se da linguagem de educação ambiental para a conscientização, sensibilização e estímulo da população à prática do ecoturismo, essas empresas podem se beneficiar tanto institucionalmente quanto na venda de seus produtos dirigidos a essa prática.

Essa associação da marca às causas de respeito à natureza tem a oportunidade de ser ainda mais clara, quando houver a integração das mensagens de educação ambiental com a mídia exterior, que, por sua vez, deverá estar integrada com a paisagem natural - landscape - no caso do engenho publicitário estar localizado em áreas de acesso aos empreendimentos ecoturísticos (zona tampão) e também integrada às paisagens urbanas.

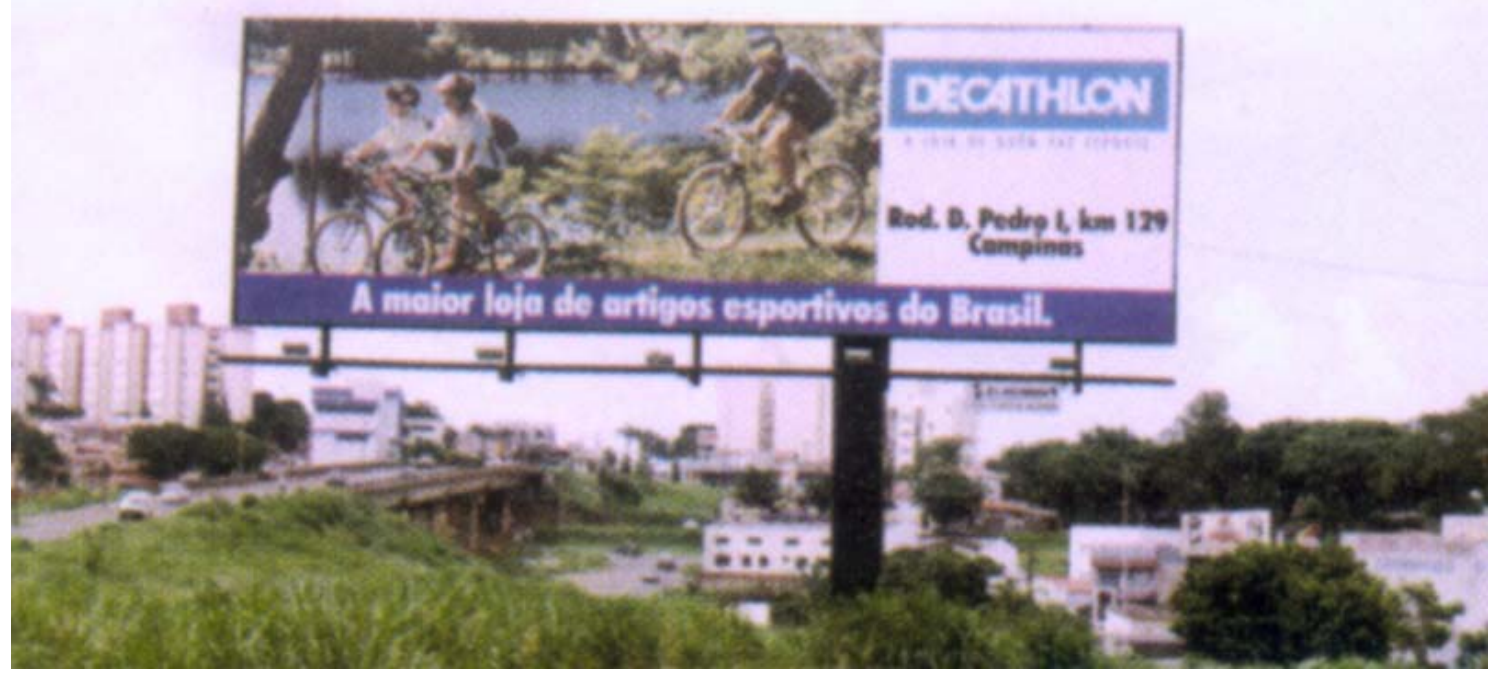

Figura 57 - "Anúncio de artigos esportivos" - Exemplo do interesse de empresas privadas em estimular práticas esportivas ao ar livre

Fonte: Jornal Meio \& Mensagem. Edição Especial. Mídia Exterior, 14 out. 2002.

\section{$\checkmark$ Bancos e operadoras de cartões de crédito}

Assim como as indústrias e empresas de varejo, os bancos e as operadoras de cartão de crédito têm na compra de pacotes turísticos grande demanda no uso dos 
seus produtos ou serviços. Até mesmo no financiamento de empreendimentos ecoturísticos, estas empresas têm muito a se beneficiar com o incremento da prática dessa nova modalidade de turismo.

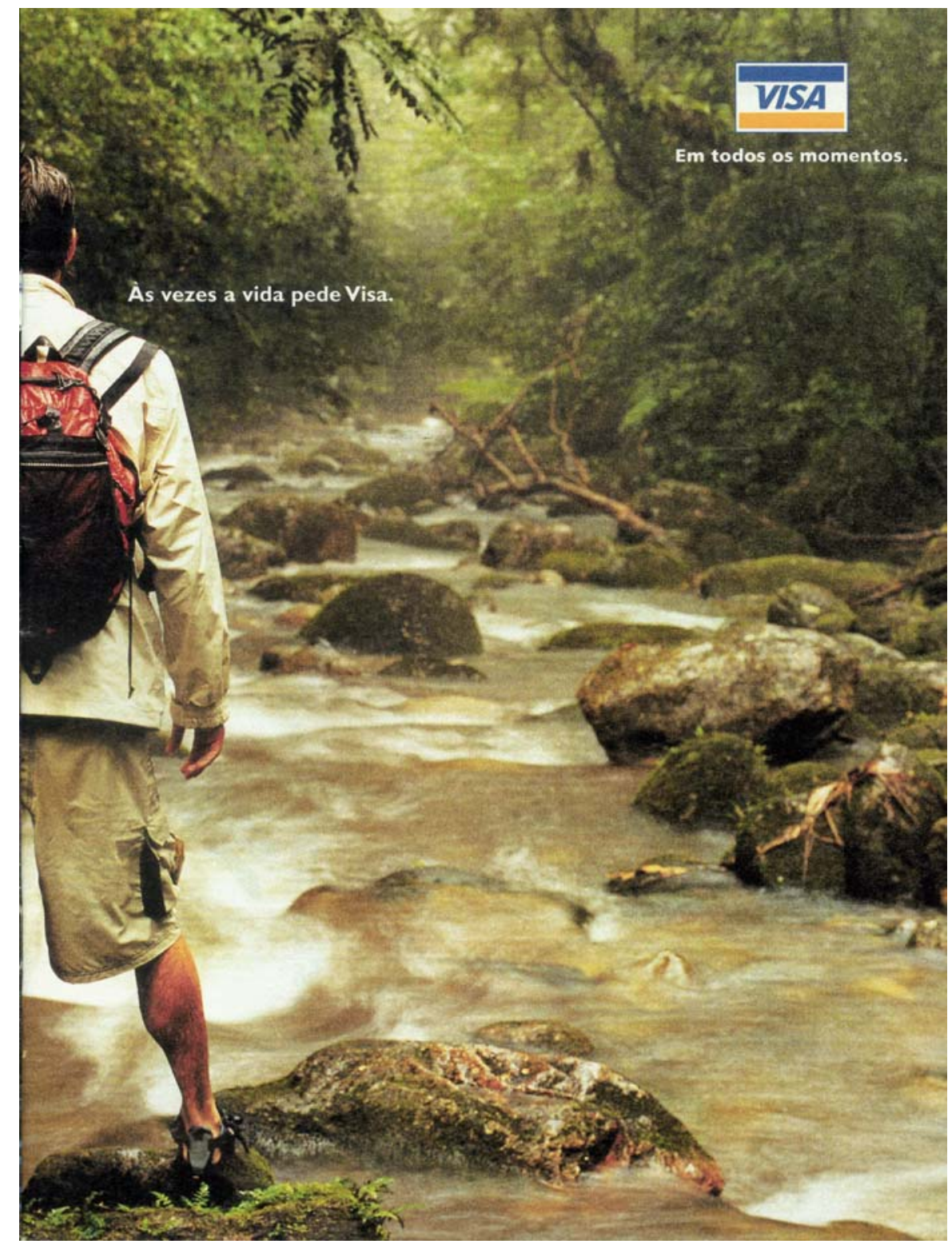

Figura 58 - "Anúncio VISA" - Exemplo do interesse em operadoras de cartões de crédito em estimular a prática do ecoturismo

Fonte: Ecologia. Revista Veja, ano 35. Edição Especial, n. 22, dez 2002, Editora Abril.

Utilizando o marketing social como estratégia de posicionamento de marcas dos diversos segmentos de empresas aqui apresentadas, para a promoção da prática ecoturística, essas mesmas instituições têm a possibilidade de usar a mídia exterior, 
integrada ao meio ambiente, seja em áreas naturais, seja nas cidades, para divulgar sua mensagem ambiental, criando consciência de respeito ao meio ambiente e de desenvolvimento sustentável.

A publicidade tem auxiliado nesse processo, sendo a interlocutora dessas empresas com seu público final, havendo várias estratégias de aproximação de um público específico a uma determinada marca. A mídia tradicional (televisão, rádio, jornal, revista, cinema) é um elo de ligação desses dois pólos (empresas/marcas e público alvo).

Integrada ao meio natural, a mídia exterior tem as características únicas de sinergia e possibilidades reais de promover uma comunicação também natural (educação ambiental) integrada e consciente, incorporando a natureza (prática do ecoturismo) ao homem. 


\section{CONCLUSÃO}

Conclui-se, portanto, que o ecoturismo tem, em sua essência, os conceitos de utilização sustentável dos recursos, de conservação do patrimônio cultural e natural, de estímulo à conscientização ambiental, por meio da integração do homem à natureza, com a promoção da melhoria de qualidade de vida das populações envolvidas. Essa conscientização e integração se dão por meio da educação ambiental, mediante suas várias possibilidades.

No sentido da divulgação, formação, conscientização e ampliação do mercado para a prática do ecoturismo, a mídia exterior surge como uma grande oportunidade de parceria com as empresas dos diversos setores de interesse nesse mercado, uma vez que a sua maior característica e vantagem estão na integração com a natureza, com as paisagens, com o landscape.

Por meio de suas características de formato e localização, e utilizando a linguagem da educação ambiental e da publicidade, a mídia exterior incorpora a relação homem / natureza, transcende o aspecto material e penetra no espaço da floresta, do campo e das águas, levando o homem a se identificar com a essência natural dos seres.

Por intermédio das características de sinergia com o meio ambiente, de exposição permanente na paisagem natural e urbana, a mídia exterior provoca uma relação com esse ambiente e inspira atitudes e comportamentos ambientalmente corretos por quem é impactado por ela.

Interagindo com as paisagens (naturais ou urbanas) e com o público consumidor (ecoturista) cumpre a função social (democrática, indistinta) de defender e conservar o meio ambiente para as presentes e futuras gerações.

Quando as mensagens veiculadas nesta mídia têm caráter educativo ambiental, conclui-se que é real a possibilidade de uma sinergia entre o ambiente, o expectador e a mídia. Este expectador pode ver as mensagens de uma forma integrada com a paisagem, não diferenciando uma da outra. Essa aproximação permite a absorção dos conceitos intrínsecos ao ecoturismo de forma natural e espontânea. 
Entende-se, por final, que o uso da mídia exterior, por meio de sua principal característica de integração às paisagens (naturais e urbanas) e sendo bem planejada, pode contribuir para a formação da consciência pública sobre a prática do ecoturismo.

Mediante a união dos interesses mercadológicos e institucionais das diversas empresas interessadas na prática dessa atividade, propõe-se a utilização dos recursos de pessoal e financeiros dessas empresas, por intermédio do marketing social, fazendo uso da linguagem e de argumentos da educação ambiental para estimular a prática do ecoturismo.

As empresas ganham em termos mercadológicos e de imagem; os consumidores sentem-se bem em consumir de uma empresa ética, ao mesmo tempo em que se conscientizam dos conceitos intrínsecos ao ecoturismo e até os funcionários dessas empresas passam a ter mais orgulho de pertencer ao seu quadro de colaboradores.

Em resumo, onde ganha a sociedade e o meio ambiente, as empresas não têm nada a perder. 


\section{REFERÊNCIAS BIBLIOGRÁFICAS}

ABNT. NBR 6023. Informação e documentação - referências - elaboração. Ago. 2000 .

ABNT. NBR 6024. Numeração progressiva das seções de um documento. Ago 1989.

ABNT. NBR 6027. Sumário. Ago. 1989.

ABNT. NBR 6028. Resumos. Maio 1990.

ABNT. NBR 10520. Informação e documentação - apresentação de citações em documentos. Jul. 2001.

ABNT. NBR 14724. Informação e documentação - trabalhos acadêmicos apresentação. Jul. 2001.

ANUÁRIO do Clube de Criação de São Paulo (27º), 2002.

ANUÁRIO do Clube de Criação do Rio de Janeiro, 2001.

BRASIL. Constituição (1988). Constituição da República Federativa do Brasil. Brasília: Senado Federal, 2002.

CASTRO, Newton de (Coord.). A questão ambiental e as empresas. Colab. De Arnaldo Augusto Setti, Antonio de Souza Gorgonio e Sueli Correa de Faria. Brasília: Edição SEBRAE, 1998.

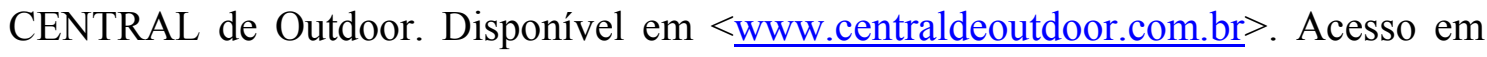
2003.

FAQUINI, Rui. Grande Oeste - imagens do Centro-Oeste do Brasil. Brasília: LGE Editora, 1999.

FARAH Service. Disponível em $<\underline{w w w . f a r a h s e r v i c e . c o m . b r}>$. Acesso em 2003.

FARIA, D.S.; CARNEIRO, K.S. Sustentabilidade ecológica no turismo. Brasília: Editora da Universidade de Brasília, 2001.

FENNELL, D.A. Ecoturismo - uma introdução. São Paulo: Contexto, 2002. 
FERREIRA, A.B.H. Novo dicionário da língua portuguesa. 2. ed. Rio de Janeiro: Nova Fronteira, 1986.

FOLDER Comercial da Mídia Plus - Anexo.

GUIA Ecológico Brasil. Região de Bonito, Mato Grosso do Sul. Guia nº 1, 4. ed. JORNAL A Tribuna. A importância da Educação Ambiental, 31 maio 1999. JORNAL Meio \& Mensagem. Mídia Exterior. Edição Especial, 14 out. 2002. JORNAL Meio \& Mensagem. Mídia Exterior. Edição Especial, 19 mar. 2001. JORNAL Valor Econômico, B3, 10 mar. 2003.

KOTLER, P.; ROBERTO L. E. Marketing social: estratégias para alterar o comportamento público. Rio de Janeiro: Campus, 1992.

KOZEL JÚNIOR, José. O top do marketing brasileiro. São Paulo: Scipione, 1997.

LEI Federal n 9.795, de 27 de abril de 1999.

MANUAL de Informações Técnicas. Nova Mídia Visuplac - Anexo.

MAURO Lemos. Disponível em <www.maurolemes.hpg.ig.com.br/conferencista tessalonica.htm>. Acesso em 2003.

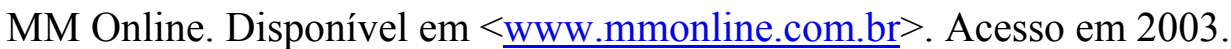

PRÊMIO Folha / Revista da Criação de Publicidade, São Paulo, 2001.

PRINGLE, Hamish; THOMPSON, Marjorie. Marketing social. São Paulo: Markron Books, 2000

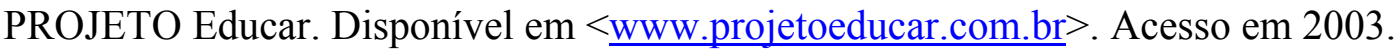

RABAÇA, C.A.; BARBOSA, G. Dicionário de comunicação. São Paulo: Ática, 1987. REVISTA About. Edição Especial. Portfolio 2002/2003. Versart Editora Artes e Comunicação Ltda.

REVISTA Portfolio Magazine, n. 1, fev 2003, Brasília, Charbel Gráfica e Editora Ltda. REVISTA Sinal Extensivo, ano 4, n. 34, set.2000, Mocarzel Edições e Promoções Ltda. REVISTA Sinal Extensivo, ano 7, n. 59, jan. 2003, Mocarzel Edições e Promoções Ltda. 
REVISTA Veja. Ano 35. Edição Especial, n. 22. Ecologia, dez. 2002, Editora Abril.

SANTOS, Guilherme de Souza. O outdoor - uma análise dessa relação. Brasília: UCB

- Universidade Católica de Brasília. Curso de Graduação em Comunicação Social, 2002.

SOCIALTEC. Disponível em $<\underline{w w w . s o c i a l t e c . o r g . b r}>$. Acesso em 2003.

VAZ, Gil Nuno. Marketing institucional: o mercado de idéias e imagens. São Paulo: Pioneira, 1995. 
ANEXOS 